\title{
Waste Isolation Pilot Plant Groundwater Protection Management Program Plan
}

July 2005

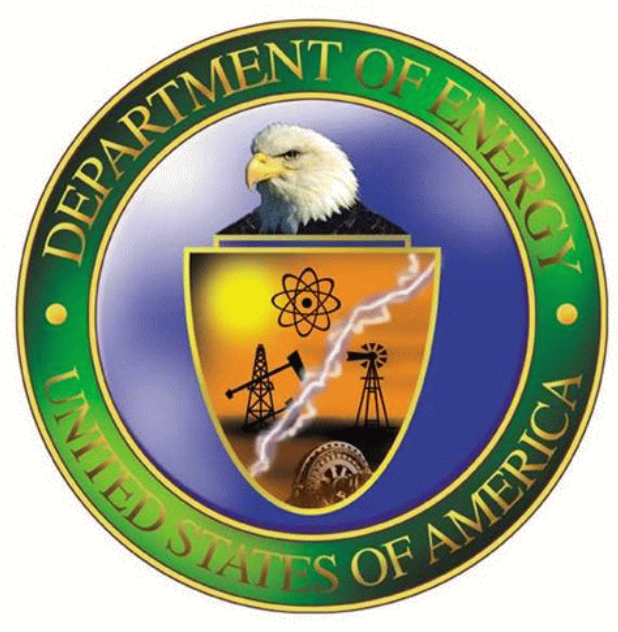

This document supersedes DOE/WIPP 96-2162, Rev. 2 
Any comments or questions regarding this plan should be directed to the Manager,

U.S. Department of Energy

Carlsbad Field Office

P.O. Box 3090

Carlsbad, NM 88221

\author{
or to the Manager, \\ Environmental Monitoring and Hydrology \\ Washington Regulatory Environmental Services \\ P.O. Box 2078 \\ Carlsbad, NM 88221
}

This plan was prepared for the U.S. Department of Energy

by the Washington Regulatory Environmental Services under contract to the Management and Operating Contractor, Washington TRU Solutions LLC, Contract No. DE-AC29-01AL66444.

This document has been submitted as required to:

Office of Scientific and Technical Information

P.O. Box 62

Oak Ridge, TN 37831

(615) $576-8401$

Additional information about this document may be obtained by calling (800) 336-9477. Copies may be obtained by contacting the National Technical Information Service, U.S. Department of Commerce, 5285 Port Royal Road, Springfield, VA 22101. 


\section{Waste Isolation Pilot Plant \\ Groundwater Protection Management Program Plan \\ DOE/WIPP 96-2162, Rev. 3}

\section{TABLE OF CONTENTS}

ACRONYMS AND ABBREVIATIONS .................... v

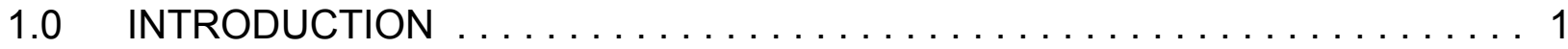

$1.1 \quad$ WIPP Mission $\ldots \ldots \ldots \ldots \ldots \ldots \ldots \ldots \ldots \ldots \ldots \ldots \ldots \ldots \ldots$

1.2 Groundwater Protection Goal $\ldots \ldots \ldots \ldots \ldots \ldots \ldots \ldots \ldots \ldots \ldots$

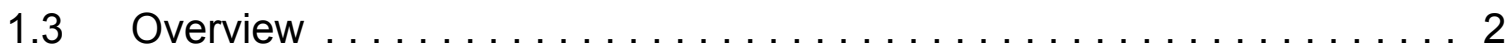

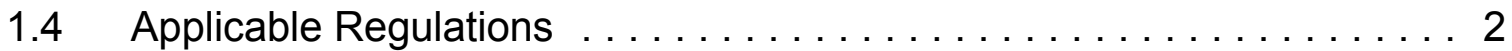

1.4.1 The Resource Conservation and Recovery Act . . . . . . . . 3

1.4.2 The Atomic Energy Act $\ldots \ldots \ldots \ldots \ldots \ldots \ldots \ldots$

1.4.3 The Comprehensive Environmental Response,

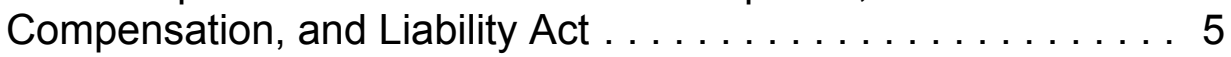

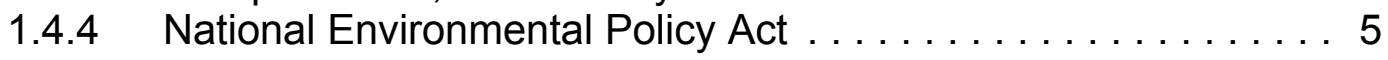

1.4 .5 Land Withdrawal Act $\ldots \ldots \ldots \ldots \ldots \ldots \ldots \ldots \ldots \ldots$

1.4.6 NMED Groundwater Quality Control Bureau . . . . . . . . . 8

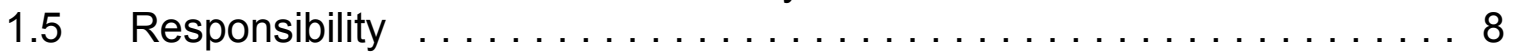

2.0 FACILITY DESCRIPTION/SITE CHARACTERIZATION $\ldots \ldots \ldots \ldots \ldots \ldots 8$

$2.1 \quad$ Facility Description $\ldots \ldots \ldots \ldots \ldots \ldots \ldots \ldots \ldots \ldots \ldots \ldots \ldots \ldots \ldots \ldots \ldots \ldots$

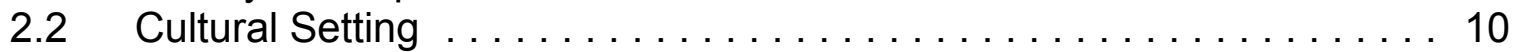

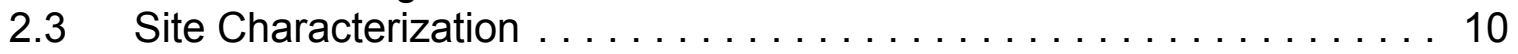

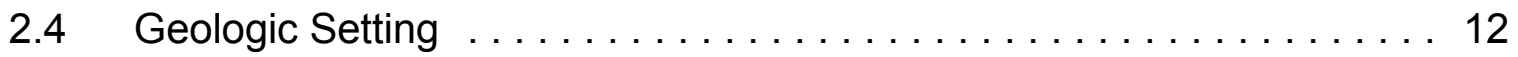

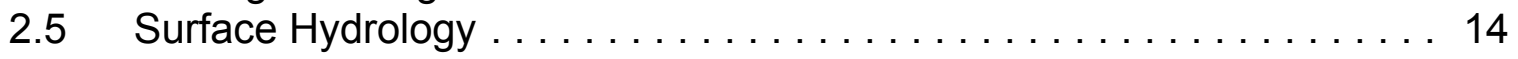

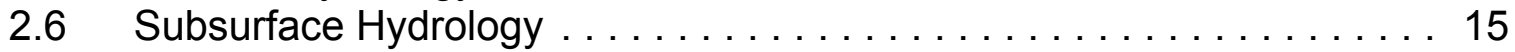

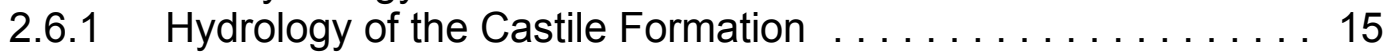

2.6.2 Hydrology of the Salado Formation .............. 15

2.6.3 Hydrology of the Rustler-Salado Contact . . . . . . . . . 16

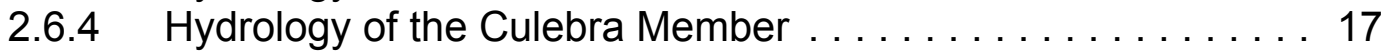

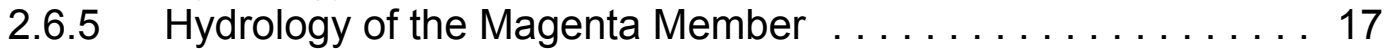

2.6.6 Hydrology of the Dewey Lake Redbeds . . . . . . . . . . 17

2.6.7 Hydrology of the Dockum Group . . . . . . . . . . . . 18

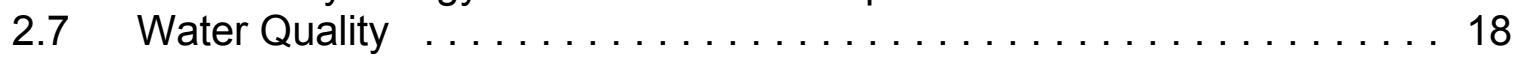

2.7.1 Rustler-Salado Contact $\ldots \ldots \ldots \ldots \ldots \ldots \ldots \ldots \ldots \ldots$

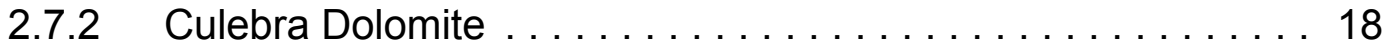

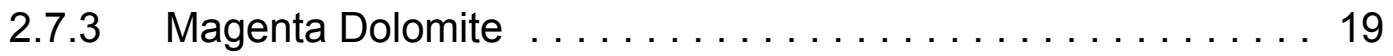

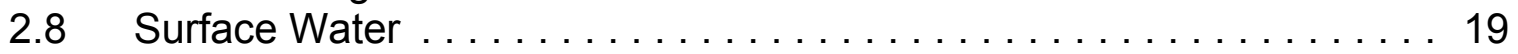

3.0 GROUNDWATER PROTECTION ................... 23

3.1 WIPP Groundwater Detection Monitoring Program Overview . . . . . . 23

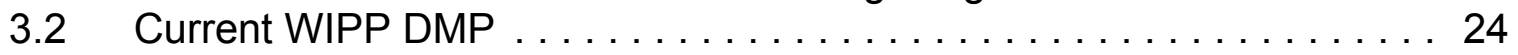

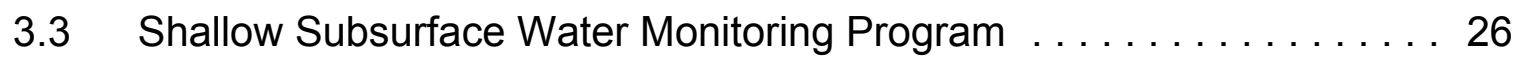

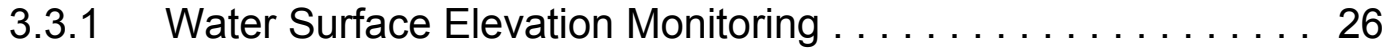

3.3.2 Water Quality Sampling .................... 27

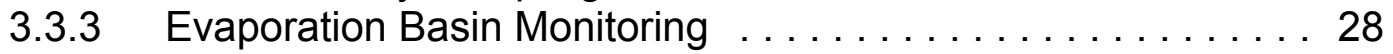

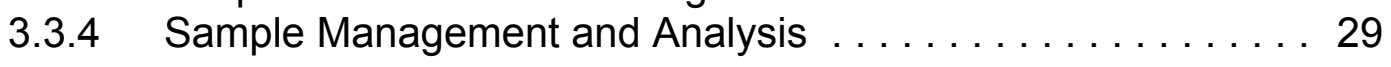




\section{Waste Isolation Pilot Plant \\ Groundwater Protection Management Program Plan \\ DOE/WIPP 96-2162, Rev. 3}

3.4 DMP Well Construction Specification $\ldots \ldots \ldots \ldots \ldots \ldots \ldots \ldots \ldots 31$

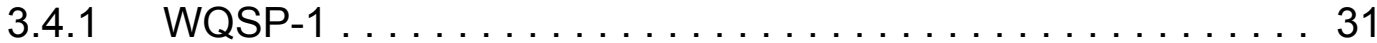

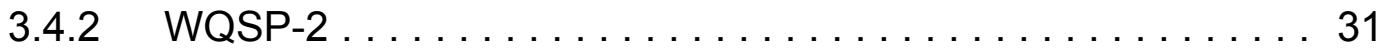

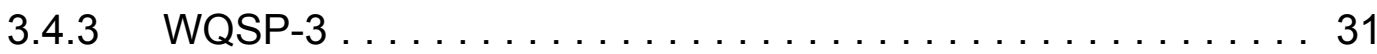

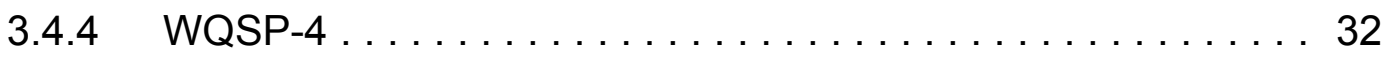

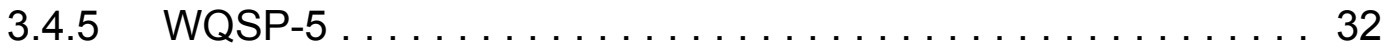

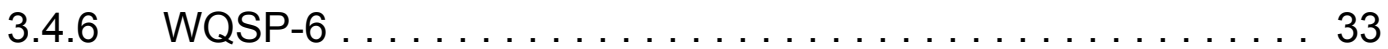

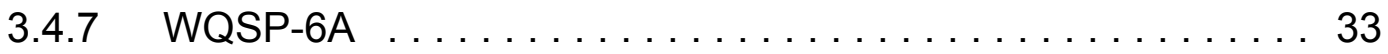

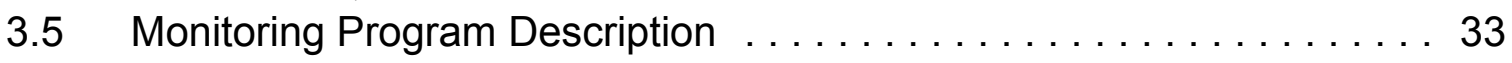

3.5.1 Monitoring Frequency $\ldots \ldots \ldots \ldots \ldots \ldots \ldots \ldots \ldots \ldots$

3.5.2 Analytical Parameters . . . . . . . . . . . . . . 34

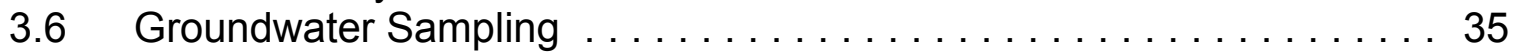

3.6.1 Groundwater Pumping and Sampling Systems . . . . . . 35

3.6.2 Pressure Monitoring Systems $\ldots \ldots \ldots \ldots \ldots \ldots \ldots \ldots$

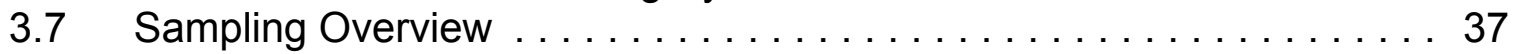

3.7 .1 Serial Samples . . . . . . . . . . . . . . . . . 37

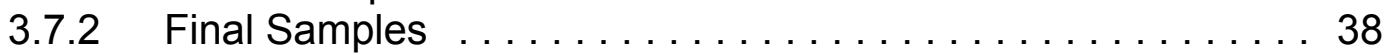

3.7.3 Sample Preservation, Tracking, Packaging, and

Transportation ..................... 40

3.7.4 Sample Documentation and Custody . . . . . . . . . . 40

3.7.5 Sample Numbers and Labels . . . . . . . . . . . . . 41

3.7 .6 Custody Seals . . . . . . . . . . . . . . . . 41

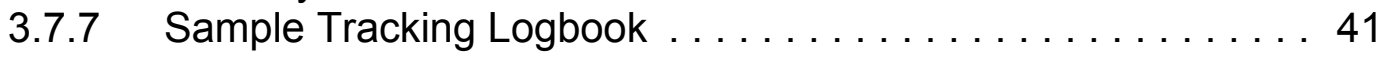

3.7.8 Request for Analysis and Chain-of-Custody Forms . . . . . . 42

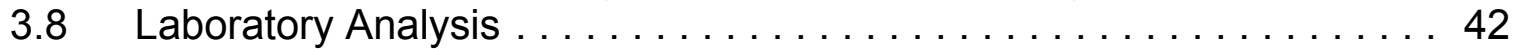

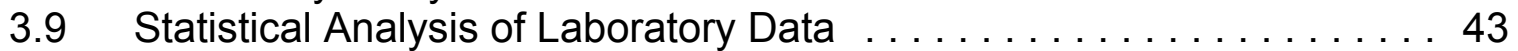

3.9.1 Temporal and Spatial Analysis . . . . . . . . . . . . 43

3.9.2 Distributions and Descriptive Statistics $\ldots \ldots \ldots \ldots \ldots .44$

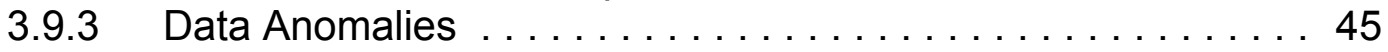

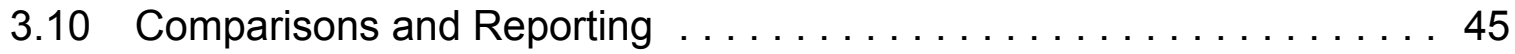

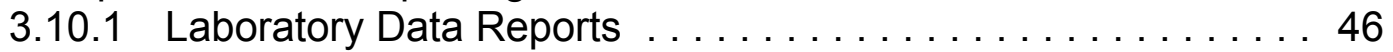

3.10.2 Statistical Analysis and Reporting of Results . . . . . . . . 46

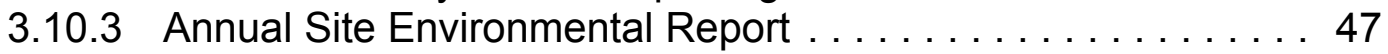

3.11 Groundwater Surface Elevation Measurement . . . . . . . . . . 47

3.11.1 Groundwater Surface Elevation Monitoring Methodology . . . 47

3.11.2 Field Methods and Data Collection Requirements . . . . . . . 49

3.11.3 Pressure Density Survey Measurements . . . . . . . . . . 50

3.11.4 Groundwater Surface Elevation Records and Document

Control ......................... 50

3.11.5 Groundwater Surface Elevation Monitoring Equipment

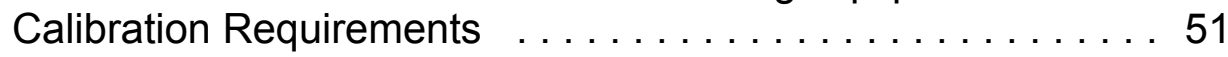

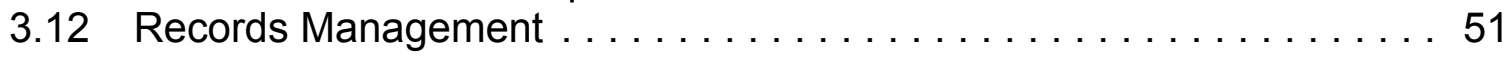

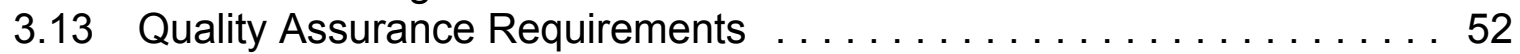

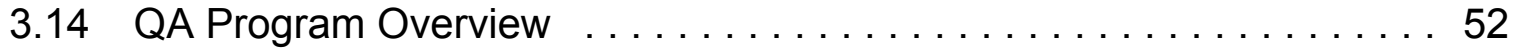

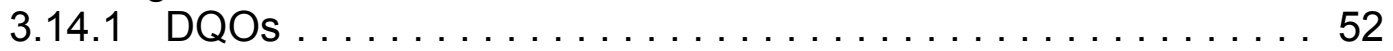

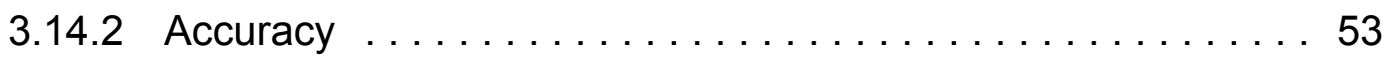




\section{Waste Isolation Pilot Plant \\ Groundwater Protection Management Program Plan \\ DOE/WIPP 96-2162, Rev. 3}

3.14.3 Precision ............................. 54

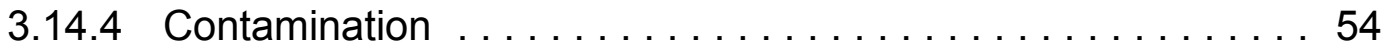

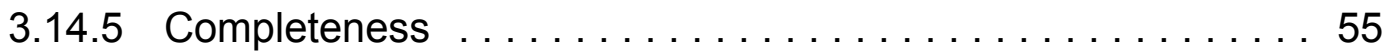

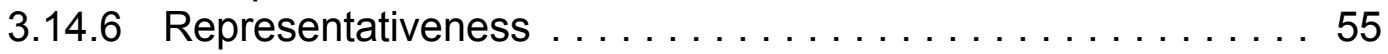

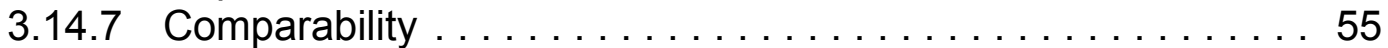

3.15 Plugging and Abandonment of Monitoring Wells ........... 56

3.15.1 Historical Profile of WIPP Wells and Justification for Abandonment .................... 57

3.15.2 Justification for Selection of Wells Scheduled for Plugging . . 57

3.15.3 Historical Profiles of Wells Scheduled for Abandonment . . . . 57

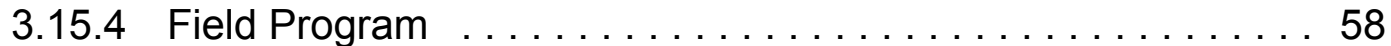

3.15 .5 Preliminary Evaluation $\ldots \ldots \ldots \ldots \ldots \ldots \ldots \ldots \ldots .58$

3.15 .6 Field Well Logging Techniques $\ldots \ldots \ldots \ldots \ldots \ldots \ldots . \ldots$

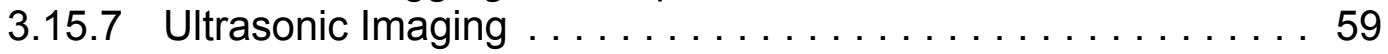

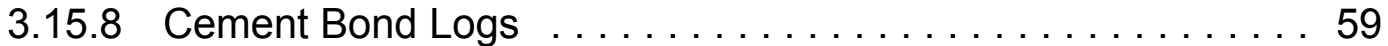

3.15 .9 Borehole Television Log $\ldots \ldots \ldots \ldots \ldots \ldots \ldots \ldots \ldots . \ldots$

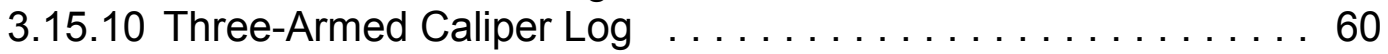

3.15.11 Regulatory Requirements $\ldots \ldots \ldots \ldots \ldots \ldots \ldots \ldots \ldots 6$

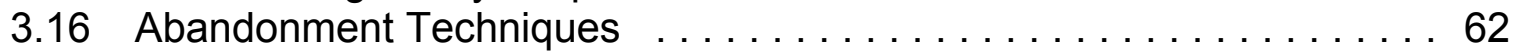

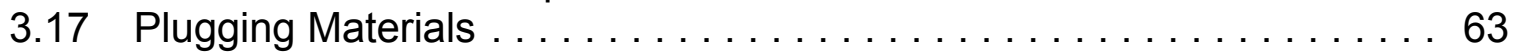

3.18 Requirements for Field Testing of Plug Integrity $\ldots \ldots \ldots \ldots \ldots 64$

3.19 Field Safety Practices . . . . . . . . . . . . . . . . . . . 64

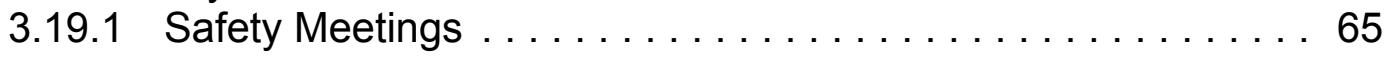

3.19.2 Prework/Orientation Conference $\ldots \ldots \ldots \ldots \ldots \ldots \ldots \ldots 65$

3.19 .3 Tailgate Safety Meetings $\ldots \ldots \ldots \ldots \ldots \ldots \ldots \ldots \ldots 6$

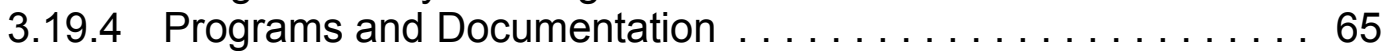

3.19.5 Accident Prevention Program $\ldots \ldots \ldots \ldots \ldots \ldots \ldots 66$

3.19 .6 Company Safety Policy $\ldots \ldots \ldots \ldots \ldots \ldots \ldots \ldots 66$

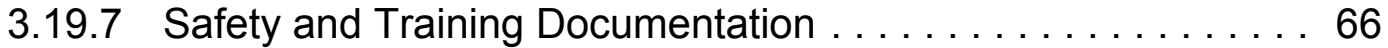

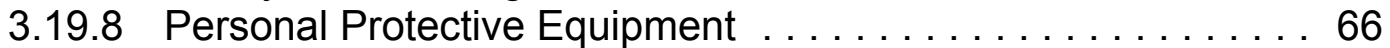

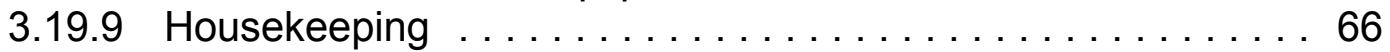

3.20 Selected Well Plugging Methodology $\ldots \ldots \ldots \ldots \ldots \ldots \ldots \ldots$

3.20 .1 Well Evaluations $\ldots \ldots \ldots \ldots \ldots \ldots \ldots \ldots \ldots \ldots \ldots \ldots$

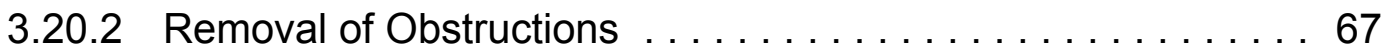

3.20.3 Casing Perforations and Squeeze Cementing of Intervals . . . 68

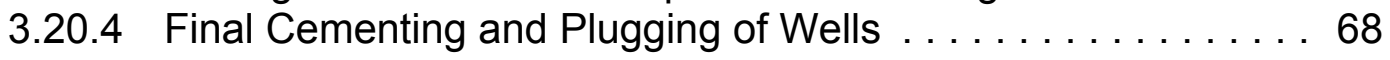

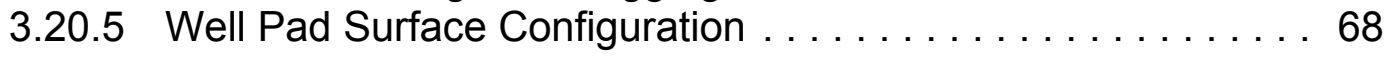

3.21 Post-Closure Monitoring . . . . . . . . . . . . . . . . . . 69

4.0 STRATEGIES FOR CONTROLLING SOURCES OF CONTAMINANTS . . . . 81

5.0 REFERENCES $\ldots \ldots \ldots \ldots \ldots \ldots \ldots \ldots \ldots \ldots \ldots \ldots \ldots \ldots \ldots \ldots \ldots \ldots \ldots$ 


\section{Waste Isolation Pilot Plant \\ Groundwater Protection Management Program Plan \\ DOE/WIPP 96-2162, Rev. 3}

\section{LIST OF TABLES}

Table 2-1 - Wells Sampled As Part of the Detection Monitoring Program . . . . . 19

Table 3-1 - Shallow Subsurface Water Analytical Parameters . . . . . . . . . . . 30

Table 3-2 - Evaporation Basins Water Analytical Parameters . . . . . . . . . . 30

Table 3-3 - WIPP Groundwater Detection Monitoring Program Sample

Collection and Groundwater Surface Elevation Measurement

Frequency . . . . . . . . . . . . . . . . . . 69

Table 3-4 - Analytical Parameter List for the WIPP DMP . . . . . . . . . . . . 70

\section{LIST OF FIGURES}

Figure $2-1$ - Location of the WIPP Site . . . . . . . . . . . . . . . 20

Figure 2-2 - Spatial View of the WIPP Facility . . . . . . . . . . . . 21

Figure 2-3 - Flow Rate and Direction of Groundwater Across the WIPP Site in the Culebra Formation . . . . . . . . . . . . . . . . 22

Figure 3-1 - Detection Monitoring Well Locations . . . . . . . . . . . . . . 71

Figure 3-2 - As-Built Configuration of Well WQSP-1 . . . . . . . . . . . . 72

Figure 3-3 - As-Built Configuration of Well WQSP-2 . . . . . . . . . . . . 73

Figure 3-4 - As-Built Configuration of Well WQSP-3 . . . . . . . . . . . . . 74

Figure 3-5 - As-Built Configuration of Well WQSP-4 . . . . . . . . . . . 75

Figure 3-6 - As-Built Configuration of Well WQSP-5 . . . . . . . . . . . 76

Figure 3-7 - As-Built Configuration of Well WQSP-6 . . . . . . . . . . . . . 77

Figure 3-8 - As-Built Configuration of Well WQSP-6a . . . . . . . . . . . 78

Figure 3-9 - Water-Level Measurement Program Wells . . . . . . . . . . . . 79

Figure 3-10 - Locations of SSW Wells (Piezometers PZ-1 through 12; Wells

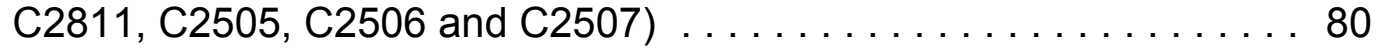




\section{Waste Isolation Pilot Plant \\ Groundwater Protection Management Program Plan \\ DOE/WIPP 96-2162, Rev. 3}

\section{ACRONYMS AND ABBREVIATIONS}

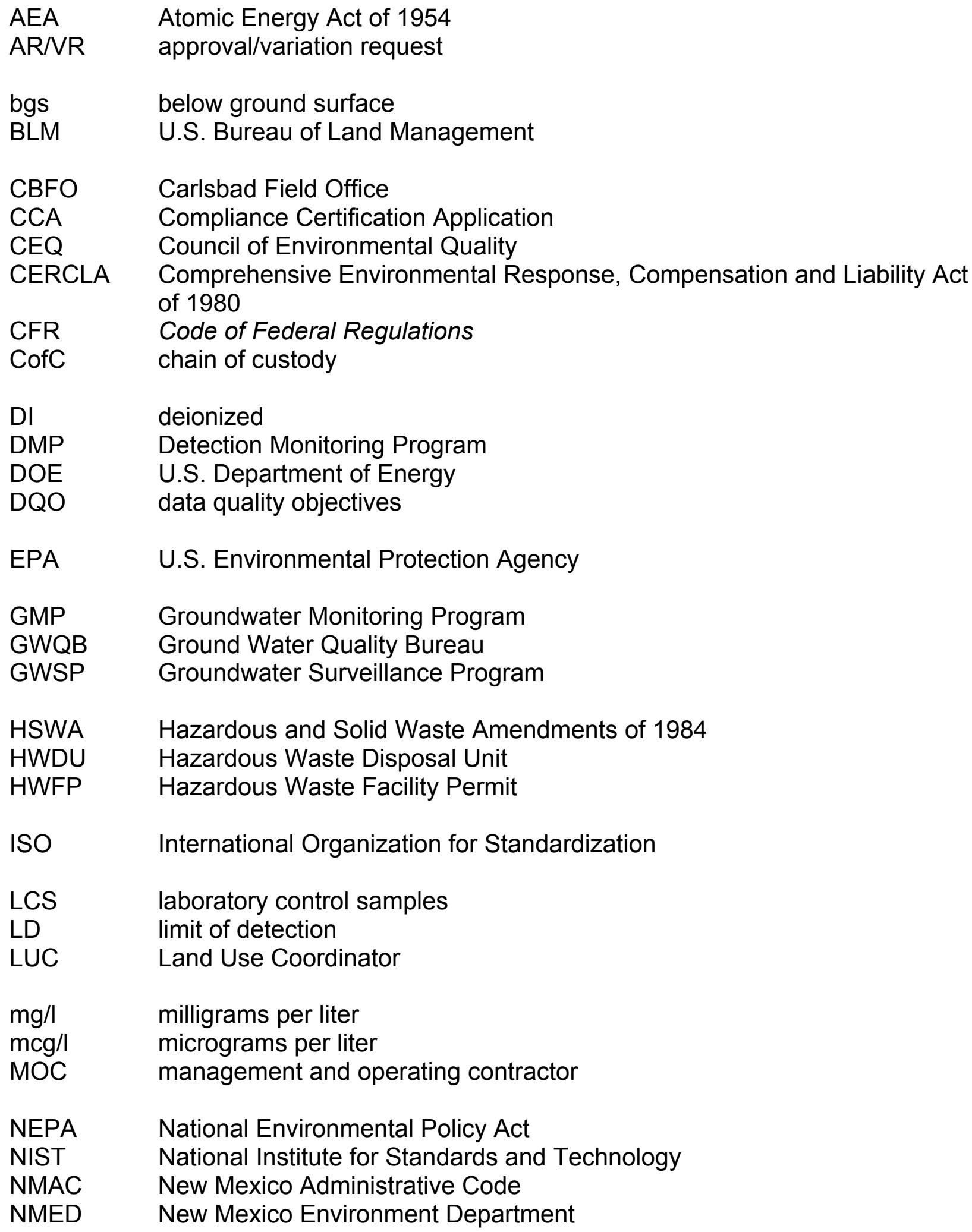




\section{Waste Isolation Pilot Plant \\ Groundwater Protection Management Program Plan \\ DOE/WIPP 96-2162, Rev. 3}

NRC U.S. Nuclear Regulatory Commission

NWPA Nuclear Waste Policy Act

OCD New Mexico Oil Conservation Division

P\&A plugging and abandonment

P2 pollution prevention

PPE personal protective equipment

QAPD Quality Assurance Program Description

QC quality control

RCRA Resource Conservation and Recovery Act of 1976

RFA request for analysis

RIDS Records Inventory and Disposition Schedule

RPD relative percent difference

SC specific conductance

SER Site Environmental Report

SOP standard operating procedure

SPEP Salt Pile Evaporation Pond

SSE Salt Storage Extension

SSW Shallow Subsurface Water

STLB sample tracking logbook

SWDA Solid Waste Disposal Act of 1976

TDS total dissolved solids

TRU transuranic

USI $\quad$ ultrasonic imaging

VOC volatile organic compound

WIPP Waste Isolation Pilot Plant

WLMP WIPP Groundwater Level Monitoring Program

WLWA WIPP Land Withdrawal Area

WQSP Water Quality Sampling Program

WRES Washington Regulatory and Environmental Services

WTS Washington TRU Solutions LLC 


\section{Waste Isolation Pilot Plant \\ Groundwater Protection Management Program Plan \\ DOE/WIPP 96-2162, Rev. 3}

\section{$1.0 \quad$ INTRODUCTION}

This document was prepared by the Washington Regulatory and Environmental Services (WRES) Environmental Monitoring and Hydrology Section. It is the responsibility of this group to review the plan annually and update it every three years.

This document is not, nor is it intended to be, an implementing document that sets forth specific details on carrying out field projects or operational policy. Rather, it is intended to give the reader insight to the groundwater protection philosophy at the Waste Isolation Pilot Plant (WIPP).

\subsection{WIPP Mission}

The WIPP facility is owned by the U.S. Department of Energy (DOE) and co-operated by its designated prime management and operating contractor (MOC), Washington TRU Solutions LLC (WTS). The WIPP facility was authorized by the DOE National Security and Military Applications of Nuclear Energy Authorization Act of 1980 (93 Statutes at Large [Stat.] 1259, 1265) with the mission to dispose of transuranic wastes generated by the defense activities of the U.S. Government in an environmentally sound and safe manner.

\subsection{Groundwater Protection Goal}

The DOE established the Groundwater Monitoring Program (GMP) (WP 02-1) to monitor groundwater resources at WIPP. In the past, the GMP was conducted to establish background data of existing conditions of groundwater quality and quantity in the WIPP vicinity, and to develop and maintain a water quality database as required by regulation. Today the GMP is conducted consistent with 204.1.500 NMAC (New Mexico Administrative Code), "Adoption of 40 CFR [Code of Federal Regulations] Part 264," specifically 40 CFR $\$ 264.90$ through $\S 264.101$. These sections of 20.4.1 NMAC provide guidance for detection monitoring of groundwater that is, or could be, affected by waste management activities at WIPP.

Detection monitoring at WIPP is designed to detect contaminants in the groundwater long before the general population is exposed. Early detection will allow cleanup efforts to be accomplished before any exposure to the general population can occur.

Title 40 CFR Part 264, Subpart F, stipulates minimum requirements of Resource Conservation and Recovery Act of 1976 (42 United States Code [U.S.C.] §6901 et seq.) (RCRA) groundwater monitoring programs including the number and location of monitoring wells; sampling and reporting schedules; analytical methods and accuracy requirements; monitoring parameters; and statistical treatment of monitoring data.

This document outlines how WIPP intends to protect and preserve groundwater within the WIPP Land Withdrawal Area (WLWA). Groundwater protection is just one aspect of the WIPP environmental protection effort. An overview of the entire environmental 


\section{Waste Isolation Pilot Plant \\ Groundwater Protection Management Program Plan \\ DOE/WIPP 96-2162, Rev. 3}

protection effort can be found in DOE/WIPP 99-2194, Waste Isolation Pilot Plant Environmental Monitoring Plan. The WIPP GMP is designed to statistically determine if any changes are occurring in groundwater characteristics within and surrounding the WIPP facility. If a change is noted, the cause will then be determined and the appropriate corrective action(s) initiated.

\section{$1.3 \quad$ Overview}

The objective of this plan is to provide an overview of the groundwater protection strategies that implement the DOE policy of protecting the environment and the public. This plan discusses the following elements:

- Documentation of the groundwater with respect to quantity and quality

- $\quad$ A groundwater monitoring program designed to support resource management and comply with applicable environmental laws and regulations

- A management program for groundwater protection and remediation

- $\quad$ A summary and identification of areas that may be contaminated with hazardous substances

- $\quad$ Strategies for controlling sources of hazardous substances

- $\quad$ A remedial action program that is part of the site Comprehensive Environmental Response, Compensation and Liability Act of 1980 (42 U.S.C. $\$ \$ 9510$ et seq.) (CERCLA) program

- Decontamination, decommissioning, and other remedial programs contained in DOE directives

Section 2.0 of this plan discusses groundwater with respect to quantity and quality. Section 3.0 addresses the groundwater monitoring program and programs for groundwater protection. Section 4.0 discusses the strategies that WIPP has implemented to control wastes and other hazardous substances.

WIPP's philosophy regarding CERCLA is identified in Subsection 1.4.3, and the site decontamination and decommissioning program is discussed in Subsection 1.4.5.

\section{$1.4 \quad$ Applicable Regulations}

The Environmental Regulatory Guide for Radiological Effluent Monitoring and Environmental Surveillance (DOE/EH-0173T), dated January 1991, requires that groundwater which may potentially be affected by DOE operations be monitored. The monitoring is performed to determine and document the effects of such operations on 


\section{Waste Isolation Pilot Plant \\ Groundwater Protection Management Program Plan \\ DOE/WIPP 96-2162, Rev. 3}

groundwater quality and quantity, and to demonstrate compliance with applicable federal and state laws and regulations.

\subsubsection{The Resource Conservation and Recovery Act}

The RCRA is a statute designed to provide "cradle-to-grave" control of hazardous waste by imposing management requirements on generators and transporters of hazardous wastes and on the owners and operators of treatment, storage, and disposal facilities.

There are two major objectives of the RCRA. The first is to promote the protection of human health and the environment and to conserve material and energy resources. This objective is to be accomplished through such means as ensuring that hazardous waste management practices are conducted so as to protect human health and the environment, minimize the generation of hazardous waste, prohibit open dumping on the land, and require existing open dumps to be converted to facilities that pose no danger to the environment or human health. The second RCRA objective is to set national policy to reduce or eliminate the generation of hazardous waste as expeditiously as possible and to ensure that any hazardous waste generated be treated, stored, or disposed of so as to minimize the present and future threat to human health and the environment.

The U.S. Environmental Protection Agency (EPA) implements the RCRA primarily through the 40 CFR Parts 260 through 282 series: 40 CFR Parts 260 through 279 consist of requirements and standards pertaining to hazardous waste; 40 CFR Parts 280 through 282 pertain to the management of underground storage tanks containing petroleum products or hazardous chemicals.

Congress intended for the RCRA program to be implemented by the states. Consequently, the EPA has defined a process through which states may apply for and receive authorization to administer the RCRA program. New Mexico received authorization for the base RCRA program in January 1985 and for its mixed waste program in July 1990. The EPA granted authorization for the Hazardous and Solid Waste Amendments of 1984 (HSWA) (42 U.S.C. 6901 et. seq.) program to the state of New Mexico in a notice that appeared in the Federal Register (FR) on October 17, 1995 (effective date: January 2, 1996). New Mexico administers its HSWA program through 20.4.1, 20.4.2, 20.4.3, and 20.5 NMAC. By virtue of this authorization, New Mexico has primary responsibility for permitting, implementation, and enforcement for most aspects of the RCRA program. The DOE has received a hazardous waste facility permit (HWFP) from the New Mexico Environment Department (NMED).

The Waste Isolation Pilot Plant Land Withdrawal Act (106 Stat. 4777), as amended, exempted waste designated by the Secretary of Energy for disposal at WIPP from the treatment standards of the Solid Waste Disposal Act of 1976 (42 U.S.C. §7001]) (SWDA). By virtue of this exclusion, the DOE Carlsbad Field Office (CBFO) is no longer required to demonstrate compliance with the Land Disposal Restrictions of 40 CFR Part 268 for waste shipped to WIPP for storage and disposal. 


\section{Waste Isolation Pilot Plant \\ Groundwater Protection Management Program Plan \\ DOE/WIPP 96-2162, Rev. 3}

The RCRA groundwater monitoring requirements are described in 20.4.1.500 NMAC, adopting 40 CFR $\S 264.601$, incorporating the requirements of 40 CFR Part 264, Subpart F. The groundwater protection information provided in Permit Module $V$ and Attachment $L$ of the draft permit describes the groundwater monitoring programs implemented at WIPP to meet the requirements of 204.1.500 NMAC, incorporating 40 CFR $\S 264.601$, these implementing programs are also discussed in Section 3.0 of this document.

\subsubsection{The Atomic Energy Act}

The Atomic Energy Act (AEA) of 1954, as amended (42 U.S.C. §§2011 et seq.), initiated a national program for research, development, and use of atomic energy for both national defense and domestic civilian purposes.

The authority of the EPA to establish generally applicable standards for the protection of the public and the environment from radiation is derived from the AEA, as amended; Reorganization Plan No. 3 of 1970; and the Nuclear Waste Policy Act (NWPA) (42 U.S.C. 10101 et seq.). The protection standards found in 40 CFR Part 191, "Environmental Radiation Protection Standards for Management and Disposal of Spent Nuclear Fuel, High-Level and Transuranic Radioactive Wastes," apply to both spent nuclear fuel and high-level radioactive waste as defined by the NWPA, and to transuranic (TRU) waste, which contains more than 100 nanocuries per gram of waste of alpha-emitting TRU isotopes with half-lives greater than 20 years. The standards of 40 CFR Part 191 consist of three subparts: Subpart A; "Environmental Standards for Management and Storage," Subpart B; "Environmental Standards for Disposal," and Subpart C; "Environmental Standards for Groundwater Protection."

Subpart A, "Standards for Management and Storage," sets the operational term requirements limiting annual doses to members of the public from management and storage operations at disposal facilities operated by the DOE and not regulated by either the U.S. Nuclear Regulatory Commission (NRC) or by agreement states. The annual dose equivalent, from all sources, to any member of the public in the general environment may not exceed 25 millirem to the whole body and 75 millirem to any critical organ.

The EPA audits the DOE's compliance with Subpart A of 40 CFR Part 191. Because Subpart A only contains environmental performance standards, implementation details are left to the responsible agency. The EPA issued guidance for implementation of Subpart A, which includes methods for dose calculation, modeling, and reporting. The DOE has issued a compliance implementation plan that adopts the EPA's guidance and outlines the 40 CFR Part 191 compliance program.

The EPA has certification authority for Subparts B and C of 40 CFR Part 191. As required by the WIPP Land Withdrawal Act in Section 8(d)(2), the EPA certified on May 18, 1998 (FR Volume 63, Number 95, pp. 27353), that the WIPP facility was in compliance with 40 CFR Part 191, Subparts B and C. This certification decision was 


\section{Waste Isolation Pilot Plant \\ Groundwater Protection Management Program Plan \\ DOE/WIPP 96-2162, Rev. 3}

made after careful consideration and evaluation of the Title 40 CFR 191 Compliance Certification Application for the Waste Isolation Pilot Plant (CCA) (DOE/CAO 96-2184). The CCA was submitted to the EPA on October 29, 1996, as specified in the WIPP Land Withdrawal Act Section 8(d)(1), and demonstrates compliance with the provisions of Subparts B and C.

The CCA groundwater requirements are described in 40 CFR Part 191 and 40 CFR Part 194, "Criteria for the Certification and Re-Certification of the Waste Isolation Pilot Plant's Compliance with the 40 CFR Part 191 Disposal Regulations." The groundwater protection information provided in the CCA are described in Chapter 8 of the CCA and CCA attachment MON. The groundwater monitoring programs implemented at WIPP to meet the requirements of 40 CFR Part 191 and 40 CFR Part 194 are discussed in Section 3.0 of this plan.

\subsubsection{The Comprehensive Environmental Response, Compensation, and Liability Act}

The CERCLA, or "Superfund," and the Superfund Amendments and Reauthorization Act of 1986, establishes a comprehensive federal strategy for responding to, and establishing liability for, releases of hazardous substances from a facility to the environment.

Any spills of reportable quantities of hazardous substances must be reported to the National Response Center under the provisions of Part 103 of CERCLA, "Notification Requirements Respecting Released Substances," and the implementing regulations in 40 CFR Part 302, "Designation, Reportable Quantities, and Notification." Because WIPP is not a CERCLA remediation site and is not expected to become one, most of the requirements of this act do not apply. Therefore, a site CERCLA program and remedial action program have not been formulated as required by DOE Order 231.1, Environment, Safety, and Health Reporting. If, in the future, the need is identified, such programs will be implemented.

The MOC is responsible for reporting and managing any release of hazardous substances at WIPP as defined in Part 101 of the CERCLA, "Definitions," in quantities equal to or greater than the reportable quantities outlined in Part 102, "Designation of Additional Hazardous Substances and Establishment of Reportable Released Quantities; Regulations," and specified in 40 CFR Part 302. In the event of a release of a hazardous substance to the environment in an amount that meets or exceeds the reportable quantity for that substance, a notification of the release is made to the appropriate agencies by MOC personnel as required by Part 103 of the CERCLA.

\subsubsection{National Environmental Policy Act}

The Council on Environmental Quality (CEQ) proceduralized National Environmental Policy Act of 1969 (NEPA) (42 U.S.C. §§4321 et seq.) objectives by promulgating the "Regulations for Implementing the Procedural Provisions of the National Environmental 


\section{Waste Isolation Pilot Plant \\ Groundwater Protection Management Program Plan \\ DOE/WIPP 96-2162, Rev. 3}

Policy Act." These regulations were published in 40 CFR Parts 1500 through 1508, on November 29, 1978, and instructed federal agencies to develop agency specific directives (regulations, plans, or orders) to implement the NEPA. General directives to federal agencies included consideration of the potential impacts of a proposed action or decisions providing necessary data to support proposed actions or decisions, and informing the public and soliciting public input in the decision making process.

Proposed actions that would modify the WIPP facility are screened to determine whether additional NEPA documents need to be prepared. These proposals may be described in a variety of documents such as test plans, engineering change proposals, engineering change orders, purchase requisitions, and selected work orders and first requests. Any actions proposed for implementation outside of the property protection area, regardless of type or category, require the preparation of an Environmental Review (ER) and a Land Use Request as defined in the Waste Isolation Pilot Plant Land Management Plan (DOE/WIPP 93-004). When appropriate, ERs are prepared to screen the proposals for potential environmental concerns. The NEPA compliance procedure describes the process used to screen proposed actions to determine if appropriate NEPA documentation has been completed. The WIPP NEPA procedure also contains guidance for the cognizant individual to use when completing ERs.

As required by NEPA, the environmental review is incorporated in WIPP's decisionmaking processes. WIPP personnel that propose to do work or implement proposals generated by non-WIPP entities are responsible for providing documentation of these proposals and ERs to the appropriate departments for review and determination.

WIPP personnel who make proposals that would have the potential to modify onsite or in-town WIPP facilities are responsible for compliance with the WIPP NEPA procedure. Compliance with this procedure involves reviewing the proposed action against a list of exempted actions, when appropriate; preparing ER forms, and waiting for a letter or signature of approval before carrying out the proposal or committing funds to implement the proposal.

WIPP personnel who develop proposals for actions or modifications outside the Property Protection Area are responsible for compliance with the WIPP NEPA procedure and the Land Management Plan. Compliance with the plan involves preparing a Land Use Request as well as an ER form. Compliance also involves obtaining approval from the Land Use Coordinator (LUC) prior to initiating the proposed activity. Instructions for completing a Land Use Request are contained in the Land Management Plan.

The LUC is responsible for reviewing Land Use Requests and participating in the approval process for actions proposed for performance outside the property protection area. The LUC assists personnel in ensuring that permit, contract, and memoranda of understanding requirements have been met prior to approving the action to proceed. This may include visually inspecting the area in question for potential impacts to resident wildlife and wildlife habitat, requiring that arrangements be made for 


\section{Waste Isolation Pilot Plant \\ Groundwater Protection Management Program Plan \\ DOE/WIPP 96-2162, Rev. 3}

archaeological surveys to be performed, and convening a meeting of the Land Management Council.

\subsubsection{Land Withdrawal Act}

The WIPP Land Withdrawal Act was enacted to withdraw land from the Secretary of the Interior and transfer those lands for the use of the Secretary of Energy for the purpose of constructing the WIPP site as a research and development site for the environmentally safe disposal of transuranic waste from the U.S. Department of Defense.

The act also provides for safe stewardship of the land and its uses while under the control of the DOE, including decontamination and decommissioning of the site. Section 13 of the act states:

(a) Plan for WIPP Decommissioning. Within 5 years after the date of the enactment of this Act, the Secretary shall submit to the Congress, the State, the Secretary of the Interior, and the Administrator, a plan for the decommissioning of WIPP. In addition to activities required under the Agreement, the plan shall conform to the disposal regulations that apply to WIPP at the time the plan is prepared. The Secretary shall consult with the Secretary of the Interior and the State in preparation of such plan.

(b) Management Plan for the Withdrawal After Decommissioning. Within 5 years after the date of the enactment of this Act, the Secretary shall develop a plan for the management and use of the Withdrawal following the decommissioning of WIPP or the termination of the land withdrawal. The Secretary shall consult with the Secretary of the Interior and the State in preparation of such plan and shall submit such plan to the Congress.

The act was amended by Pub. L.104-201 September 1996 and Section 13 was changed to the following language:

The Secretary shall develop a plan for the management and use of the Withdrawal following the decommissioning of WIPP or the termination of the land withdrawal. The Secretary shall consult with the Secretary of the Interior and the State in preparation of such plan and shall submit such plan to the Congress.

Therefore, a final decontamination and decommissioning plan for the site, that meets the requirements of the act has not been written. A conceptual decontamination and 


\section{Waste Isolation Pilot Plant \\ Groundwater Protection Management Program Plan \\ DOE/WIPP 96-2162, Rev. 3}

decommissioning plan is presented in the CCA. The conceptual plan was written in a manner that coincided with many of the requirements specified in DOE Order 5820.2A, Radioactive Waste Management; and ASTM [American Society for Testing and Materials) E1167-87, Standard Guide for Radiation Protection Program for Decommissioning Operations.

A final decontamination and decommissioning plan is written in accordance with Pub. L. 102-579 as amended by Pub. L. 104-201. Until such time as the final plan is written the conceptual plan presented in the CCA should be referenced as a guideline.

\subsubsection{NMED Groundwater Quality Control Bureau}

The Shallow Subsurface Water (SSW) Program (Subsection 3.3) is regulated under 20.6.2 NMAC by the NMED Ground Water Control Bureau (GWQB). The Water Quality Act of New Mexico (NMSA 1978), provides the statutory authority for provisions in 20.6.2 NMAC, which provides regulatory protection of groundwater and surface water from discharges.

The WIPP facility has one discharge permit (DP-831) issued by the NMED GWQB for the facultative sewage lagoon system and a lined evaporation pond $(\mathrm{H}-19)$. This permit has matured through several renewals and modifications.

The most recent discharge permit modification was issued by the NMED in December 2003. This modification contains permit conditions in addition to the preexisting requirements for the sewage lagoon and the $\mathrm{H}-19$ evaporation pond. This modified permit requires the closure of the salt storage area with a synthetic liner and soil cover, synthetically lining the former salt pile evaporation pond. The other component to the permit is a monitoring program for the lined retention ponds and the monitoring wells and piezometers for the shallow subsurface water (Subsection 3.3).

\section{$1.5 \quad$ Responsibility}

WTS, as the WIPP MOC, is responsible for protecting groundwater. The Environmental Monitoring and Hydrology manager, together with the Site Environmental Compliance manager, is responsible for the routine monitoring, analysis, and planned protection of groundwater at WIPP, as required by 40 CFR Part 264, 40 CFR Part 191, 40 CFR Part 194, and 20.4.1 NMAC.

In order to properly protect the environment, WIPP procedures require that all work requests and purchasing activities be reviewed and approved by Environmental Compliance prior to the initiation of work.

\section{$2.0 \quad$ FACILITY DESCRIPTION/SITE CHARACTERIZATION}

This section provides a description of the facility, and a summary of past site characterization efforts. 


\section{Waste Isolation Pilot Plant \\ Groundwater Protection Management Program Plan \\ DOE/WIPP 96-2162, Rev. 3}

\subsection{Facility Description}

The WIPP facility was authorized by Pub. L. 96-164. The facility's legislative mandate is to provide a research and development facility to demonstrate the safe disposal of radioactive waste resulting from national defense activities and programs. To fulfill this mandate, WIPP has been designed to:

- $\quad$ Perform scientific investigations of the behavior of bedded salt and the interactions between the salt and radioactive wastes.

- Demonstrate the environmentally safe and efficient handling, transportation, and emplacement of transuranic (mixed) waste in a fully operational disposal facility.

The site is located within Eddy County, 40 kilometers (26 miles) southeast of Carlsbad, New Mexico, in an area known as Los Medaños (Figure 2-1). This area is relatively flat and sparsely inhabited with little water and limited land uses. Most of the land in the area is federally or state owned and primarily used for livestock grazing. Other uses of the land in the area include potash mining and oil and gas exploration and production. The WIPP site consists of 16 sections of federal land located in Township 22 South, Range 31 East. The land was withdrawn from the application of public land laws on October 30,1992, by the WIPP Land Withdrawal Act. Surface land uses remain largely unchanged. Mining and drilling are prohibited in the 16 sections for purposes other than support of the WIPP Project with the exception of Township 22 South, Range 31 East, Section 31. This section has been condemned to no drilling within the first 6,000 feet of the surface, however, mineral reserves located below 6,000 feet can be extracted by slant drilling from outside the 16 sections subject to DOE review and comment of the application for permit to drill for the proposed well.

The WIPP site is divided into five basic areas, these are:

1. The Property Protection Area - The property protection area is approximately 33 acres at the center of the site surrounded by a chain link security fence. This area contains the facility surface structures to accommodate personnel, equipment, and support services facilities required for the receipt, preparation, and transfer of waste from the surface to the underground facilities.

2. The Exclusive Use Area - The exclusive use area is approximately 277 acres surrounding the property protection area and is fenced with barbed wire. Land uses other than DOE activities are strictly prohibited within the exclusive use area.

3. The Off Limits Area - The off limits area is approximately 1,454 acres surrounding the property protection area at its center. This area is restricted in land use to DOE activities, with the exception of grazing for livestock. 


\section{Waste Isolation Pilot Plant \\ Groundwater Protection Management Program Plan \\ DOE/WIPP 96-2162, Rev. 3}

4. $\quad$ The WIPP Land Withdrawal Area - The WLWA consists of 16 sections surrounding the first three areas.

5. The Underground Area - The underground area indicates the maximum extent of underground development. The underground structures are located 655 meters $(2,150$ feet) below the land surface and consists of the waste storage facility, and underground support areas such as workshops, core storage areas, and experimental areas.

\section{$2.2 \quad$ Cultural Setting}

The primary use of land within 16 kilometers (10 miles) of the center of the site is cattle ranching. At present, the J. C. Mills ranch uses water wells approximately 3 miles from the site to water livestock. The Smith Ranch used well water until 1978, but the water quality was poor and they now use water supplied by pipeline. Drinking water for the Smith Ranch, comes from IMC Potash (IMC), a potash resource mining facility, which has its own well system tapping the Capitan Aquifer. Stock water comes from IMC and from New Mexico Potash Corporation, which has a well system tapping the Ogallala Formation (Contact-Handled [CH] Documented Safety Analysis Report, DOE/WIPP 95-2065).

Water is furnished to the WIPP site in raw form by the Double Eagle Water Supply System. The water is chlorinated at the site for general purpose and potable use. The Double Eagle Water Supply System is operated by the city of Carlsbad.

The majority of the local population within 80.5 kilometers (50 miles) of WIPP is concentrated in and around the communities of Carlsbad, Hobbs, Eunice, Loving, Jal, Lovington, and Artesia, New Mexico. The estimated population within this radius is 100,944 . The nearest community is the village of Loving (current estimated population $1,326), 29$ kilometers (18 miles) west-southwest of WIPP. The nearest major populated area is Carlsbad, 42 kilometers (26 miles) west of WIPP. The current estimated population of Carlsbad is 25,625 .

The nearest residents to the site are located at two neighboring ranches, 5.8 kilometers (3.5 miles) south-southwest of the center of the site, and 10 kilometers (6 miles) west-northwest of the center of the site. The transient population within 10 miles of WIPP is associated with ranching, oil and gas exploration/production, and potash mining.

\subsection{Site Characterization}

Since the mid 1970's, an extensive program of site characterization and validation was conducted at the WIPP site. The results of these studies were summarized in numerous publications, including the WIPP "Geological Characterization Report" (Powers et al., 1978); the WIPP Safety Analysis Report; the WIPP Design Validation Final Report (DOE/WIPP 86-010) (U.S. DOE, 1986); and "Summary of 


\section{Waste Isolation Pilot Plant \\ Groundwater Protection Management Program Plan \\ DOE/WIPP 96-2162, Rev. 3}

Site-Characterization Studies Conducted from 1983 Through 1987 at the Waste Isolation Pilot Plant (WIPP) Site, Southeastern New Mexico" (Lappin, 1988). These studies substantiate the conclusion that the possibility of migration of waste from the WIPP facility by groundwater is quite remote. The nature of the WIPP site indicates there would be very little groundwater available to mobilize and transport waste. Therefore, very little groundwater could come in contact with waste and there is very little possibility that any contaminated groundwater could migrate from the WIPP facility's storage horizon to the accessible environment.

The WIPP facility horizon is located 655 meters $(2,150$ feet) below the land surface in the Salado Formation, a bedded halite formation. The thick sequences of predominantly very low to low permeability sediments and evaporites isolate the waste storage horizon from any infiltration from the surface as well as from overlying water-bearing units. The facility storage horizon is isolated from the underlying water-bearing formations by about 640 meters (2,000 feet) of sediments and evaporites.

In recent years, however, water has been observed leaking into the exhaust shaft between $50-80$ feet below ground level. The origin and characteristics of the water is being studied and monitored. Studies indicate that the water leaking into the shaft is from an unconfined, perched water table at the base of the Santa Rosa Formation. This section of the Santa Rosa is believed to be recharged from rainfall events that collect in surface impoundments near the WIPP site, such as the north salt storage catchment basin and the runoff catchment basins to the south of the site. No hydraulic connection has been established between the water located in the Santa Rosa and the water bearing formations of the Rustler Formation (DOE/WIPP 99-2302).

The only source of water available to contact waste disposed of at WIPP is from the very small amounts of trapped Permian brine that have been observed in the various drill holes in the facility horizon (Deal et al., 1991, DOE/WIPP 91-036). Insufficient quantities of liquid are available to serve as a potential transport medium during operations. Evaporation of the moisture due to the normal mine ventilation prevents the accumulation of sufficient quantities of brine which could come in contact with the waste itself. Because free liquids will not be stored in the WIPP facility, these small amounts of brine are the only source of liquids found in the storage horizon. It will not be possible, therefore, for waste to migrate hydraulically in any water-bearing unit or the accessible environment during the operational period of the facility.

During the post-operational and post-closure periods at WIPP, other factors relative to waste migration potential must be considered. A preliminary seal design report was issued that describes various alternatives for sealing the facility and all the shafts, boreholes, and drifts leading to the facility (Stormont, 1988). The seals are designed to limit the inflow of water to the facility from overlying water-bearing units and from precipitation. The seal design also limits the movement of any contaminated brine from the facility through shafts to the accessible environment. At the same time, the salt formation will be closing around the waste containers and closing mined openings due to the natural creep of the host salt. This creep closure is expected to improve the 


\section{Waste Isolation Pilot Plant \\ Groundwater Protection Management Program Plan \\ DOE/WIPP 96-2162, Rev. 3}

effectiveness of engineered barriers (seals, backfills, etc.) and limit the pore volume in the facility available to brine inflow from any source, such as brine seepage from the host formation or from seepage through seals from overlying water-bearing units (Nowak, 1988).

The amount of accumulated brine in the facility at the time when the salt has closed around the waste is expected to be minimal. The plugging and sealing of the facility in addition to the natural closure of the salt rooms minimizes the amount of contaminated brine that can occur in the facility. These factors also ensure that any such brine will be trapped in the facility storage horizon with little likelihood of mobilization into groundwater resources.

To summarize, in order for waste to migrate to groundwater-bearing units there must first be a transport mechanism, in this case water or brine. There must be a pathway, such as a shaft or a drill hole that connects the contaminated brine with overlying water-bearing units. Proper sealing of the facility ensures that there will be no viable pathway available for the transuranic waste and hazardous waste constituents to migrate to the overlying or underlying water-bearing units.

\section{$2.4 \quad$ Geologic Setting}

The WIPP site is located on the eastern edge of the Pecos Valley section of the southern Great Plains physiographic province. The land surface within the area of the site is a monotonous, semiarid eolian plain sloping gently to the west and southwest. Its surface is made somewhat irregular by an abundance of sand ridges and dunes. Within the vicinity of the WIPP site, elevations range from 1,082 meters (3,550 feet) above mean sea level in the east to 1,006 meters $(3,300$ feet) in the western part of the site.

Livingston Ridge is perhaps the most prominent physiographic feature. Located about a mile beyond the northwestern border of the WIPP site, it is a northeast-southwest trending, west-facing escarpment about 23 meters (75 feet) high, marking the east edge of Nash Draw. Nash Draw, the nearest drainage course of any significance in the vicinity of the site, is a shallow, 8 kilometers ( 5 miles) wide valley open to the southwest. Elevations within Nash Draw, which descend from about 1,006 meters (3,300 feet) at its northeast head to 898 meters (2,945 feet) at the salt lake near the Pecos River, are generally 61 to 91 meters (200 to 300 feet) lower than the surrounding terrain and may reflect substantial subsurface dissolution of salt from the Rustler and Salado Formations and accompanying subsidence of overlying materials. Livingston Ridge marks the approximate boundary between terrain to the west that has undergone subsurface as well as surface erosion and/or solution collapse and terrain to the east that has not been significantly affected.

East of the site, the nearest major drainage course is the southeast-trending San Simon Swale, some 24 kilometers (15 miles) or more distant. It, too, may owe part of its decreased elevation to subsurface dissolution. Between San Simon Swale and the WIPP site, a broad, low mesa named "The Divide" occurs about 10 kilometers (6 miles) 


\section{Waste Isolation Pilot Plant \\ Groundwater Protection Management Program Plan \\ DOE/WIPP 96-2162, Rev. 3}

east of the site, rising about 31 meters (100 feet) above the surrounding terrain and attaining an elevation of about 1,158 meters (3,800 feet). This mesa marks a local boundary between general southwest drainage toward Nash Draw and general southeast drainage toward San Simon Swale. The divide is capped by the Ogallala Formation, and overlying cap rock caliche upon which have formed small, elongate depressions similar to those found developed on the Ogallala of the High Plains.

Surface drainage in the site area is intermittent; the nearest perennial stream is the Pecos River, more than 22.4 kilometers (14 miles) southwest of the center of the site. Surface runoff in the area finds its way to the Pecos River via Nash Draw; discharge of shallow groundwater is likewise believed to be controlled by the Pecos River. Although basins like Nash Draw may have evolved partly through active subsurface dissolution of thick, buried salt deposits, there is no evidence available at present to evaluate differences in rates of dissolution which may have prevailed under different climatic conditions. That the site is in a natural divide between drainage basins indicates that it is protected from serious flooding and erosion from heavy runoff. Should the climate of the region become more humid in the future, any perennial streams which might then arise would be expected to flow through the present basins, and Nash Draw and San Simon Swale would undergo the greatest amount of erosion from this increased humidity, leaving the divide area relatively intact.

The overall geology and structure of the WIPP site is quite simple. It is characterized by a persistent, gentle homoclinal dip toward the east of 15 to 61 meters per kilometer (50 to 200 feet per mile, two degrees or less). Successively, older rocks occur toward the west, the result of erosional beveling of the gently eastward-dipping strata.

Beneath a thin but persistent veneer of windblown sand at the site are sediments representing Pleistocene, upper Triassic, and uppermost Permian strata, all of which occur above the evaporite sequence. Sandstone of the Gatuña Formation, capped by Mescalero caliche, also developed in Pleistocene time. This Mescalero caliche is of interest primarily for the geochronologic and paleoclimatic implications of its presence. It was deposited, and much of the caliche on its surface is believed to have developed, half a million years ago (Kansan-Yarmouth time) (Bachman, 1974). Between the Pleistocene sandstone and the evaporite sequence is a 152-meter (500-foot) thick succession of non-marine Redbeds of Late Triassic age (Santa Rosa Sandstone) and marine redbeds of latest Permian age or earliest Triassic (Dewey Lake Redbeds). This redbed sequence thins westward and thickens eastward, having been beveled to the west by one or more post-late Triassic erosional episodes. The thickness of redbed deposits remaining above the evaporite sequence, is crudely proportional to the degree to which the underlying salt horizons have been protected from surficial processes leading to erosion and dissolution.

At the center of the site, all but the uppermost 15 meters (50 feet) of the 5,486 meters $(18,000$ feet) of strata are of Paleozoic age, the Dewey Lake Redbeds being the topmost of the Paleozoic rocks. The Permian section alone, about 3,901 meters $(12,800$ feet) thick, constitutes over two-thirds of the sedimentary column. The Permian 


\section{Waste Isolation Pilot Plant \\ Groundwater Protection Management Program Plan \\ DOE/WIPP 96-2162, Rev. 3}

section is divided into four series, the three lowest, the Wolfcampian, the Leonardian, and the Guadalupian, contain thick clastic sequences. The uppermost series, the Ochoan, contains the evaporite formations which in descending order are the Rustler, the Salado, and the Castile Formations. The top most Ochoan Formation, the Dewey Lake Redbeds, is not part of the evaporite sequence but represents a return of clastic, normal marine deposition.

The Rustler, which overlies the Salado, contains the largest percentage of clastic material of the three evaporate formations. However, where its original thickness of around 137 meters (450 feet) has been protected from salt dissolution, about 70 percent of the formation is composed of evaporite beds, including about 40 percent rock salt.

The 610-meter (2,000 feet) thickness of the salt-rich Salado Formation is divided into three members by the recognition of a middle member referred to as the McNutt Potash Member, which is the interval within the Salado that contains the potential reserves of potash minerals mined in the Carlsbad Potash District. The lowest member of the Salado, beneath the McNutt potash member, is the member that contains the nearly pure halite in which the WIPP storage level lies. The Castile Formation beneath the Salado also contains nearly pure beds of halite but, unlike the Salado, also contains massive anhydrite beds.

The rest of the Permian section beneath the evaporite sequence, together with the subjacent Pennsylvanian and possibly Late Mississippian sections, contain dominantly clastic rocks that represent deposition during the time in which the Delaware Basin existed as a distinct structural entity. These pre-evaporite, basinal sediments, which total about 3,353 meters (11,000 feet) in thickness beneath the site, have been targeted for petroleum exploration at one point or another throughout the Delaware Basin. They contain nearly all of the region's known potential reserve of hydrocarbons.

The remainder of the Paleozoic section (Mississippian down through the Ordovician) consists of about 914 meters (3,000 feet) of mainly carbonate strata deposited in shallow-water shelf conditions over a period of long-sustained crustal stability. The underlying crystalline basement is believed to be a granitic terrain formed about 1.3 billion years ago. The only other igneous rocks known in the area occur as a lamprophyre dike rock intruded into the evaporite beds along a single northeast dike trend that approaches no closer than about 13 kilometers (8 miles) northwest of the center of the WIPP site.

\subsection{Surface Hydrology}

Surface water is absent at the WIPP site. The nearest significant surface water body, Laguna Grande de la Sal is about 13 kilometers (8 miles) west-southwest of the center of the WIPP site in Nash Draw where shallow brine ponds occur. The only other surface water is the Pecos River, which is about 22.4 kilometers (14 miles) southwest of the center of the WIPP site at its closet point. Small livestock water holes ("tanks") occur several kilometers from the WIPP site, but are not hydrologically connected to the 


\section{Waste Isolation Pilot Plant \\ Groundwater Protection Management Program Plan \\ DOE/WIPP 96-2162, Rev. 3}

formations overlying WIPP. The source of water in these tanks is runoff from precipitation (Hunter, 1985).

\subsection{Subsurface Hydrology}

Several water-bearing zones have been identified and extensively studied near WIPP. Limited amounts of potable water are found in the Dewey Lake Redbeds and the overlying Triassic Dockum group in the vicinity of WIPP. Two water-bearing units, the Culebra and Magenta dolomite, occur in the Rustler Formation and produce brackish to saline water in the vicinity of the site. Another saline water-bearing zone identified is the Rustler-Salado contact. These water-bearing horizons, which occur above the WIPP storage facility horizon, are described below. Brine and gas occurrences in the Salado and Castile Formations are also described below.

\subsubsection{Hydrology of the Castile Formation}

The Castile Formation is composed of a sequence of three thick anhydrite beds separated by two thick halite beds. This formation acts as an aquitard, separating the Salado Formation from the underlying water-bearing sandstones of the Bell Canyon Formation. Except for the isolated brine reservoirs locally found in the fractured anhydrites, very little hydrologic data are available from the Castile Formation (Mercer, 1987). In the halite zones, the occurrence of circulating groundwater is restricted because halite at these depths does not readily maintain secondary porosity, open fractures, or solution channels. Drill stem tests conducted in the Castile Formation show the permeabilities of the anhydrite and salt beds underlying WIPP to be negligible. The majority of tests revealed that values for permeabilities were too low to be determined accurately with conventional methods. Based on the limitations of the instrumentation to measure these very low permeabilities, a conservative estimate for permeability would be less than 0.1 microdarcy (Mercer, 1987).

No regional groundwater flow system is present in the Castile Formation. The only significant water present in the formation occurs in isolated brine reservoirs in fractured anhydrite. The brine occurrences are described in several reports (Popielak et al., 1983; Mercer, 1983; Griswold, 1980). Geochemical data support the hypothesis that the brines represent trapped Permian sea water that is now in equilibrium with the host rock. Therefore, these brine reservoirs are not increasing in volume or pressure, are unconnected with surrounding aquifers or the surface, and have little potential to dissolve the host rocks or move through them.

\subsubsection{Hydrology of the Salado Formation}

The massive halite beds within the Salado Formation host the WIPP facility horizon.

The Salado Formation represents a regional aquiclude due to the hydraulic properties of the bedded halite that forms most of the formation. In the halites, the presence of circulating groundwater is restricted because halites do not readily maintain primary porosity, solution channels, or open fractures. During the mapping that was conducted 


\section{Waste Isolation Pilot Plant \\ Groundwater Protection Management Program Plan \\ DOE/WIPP 96-2162, Rev. 3}

as part of the construction of the Waste Handling and Exhaust Shafts, the Salado Formation did not produce any observable fluid inflow (Holt and Powers, 1984; 1986). In addition, significant brine flows have not been encountered in hydrologic testing from the surface (Lappin, 1988).

Limited hydrologic testing has been conducted within the Salado Formation. The results of the permeability testing, both within the facility and from the surface, are generally consistent with a permeability of the undisturbed salt mass of approximately 0.001 to 0.01 microdarcy, with no distinguishable strata variability (Lappin, 1988). This indicates that any fluid flow within the competent salt is extremely slow and would result in an imperceptible rate of fluid movement in conventional hydrologic considerations. The only significant variation to these extremely low permeabilities occurs in the immediate vicinity of the underground workings. Gas-flow permeability tests indicate a marked increase in the permeabilities within approximately 1.8 to 2.1 meters (6 to 7 feet) of the underground working (Stormont et al., 1987). This apparent increase in permeability is restricted to the disturbed zone immediately surrounding the excavation and is believed to be a result of near-field fracturing and possible matrix dilation due to stress relief.

Minor quantities of gas and brine have been encountered in the salt beds of the WIPP excavation, as described by Deal and Case (1987). The inflows of brine occur as "weeps" on the exposed surfaces of the underground workings and as accumulations in some of the boreholes drilled outward from the workings, most noticeably in the down holes. Gas is usually associated with the brine inflow and can be observed as gas bubbles in the brine occurrences. The amount of brine that occurs naturally in the rock is in the order of 0.1 to 0.5 percent by weight of the surrounding rocks. Most of the measured brine inflows in boreholes have ranged between a few tenths to a few hundredths of a liter per day. The liquid and gas movement observed in the walls, floors, and roof of the excavated surfaces are believed to be the result of the pressure gradient caused by the excavation. In addition, the variability of the fluid compositions near the WIPP workings observed by Stein and Krumhansl (1986) is consistent with there being little or no vertical fluid movement. During the operational phase, virtually all of the moisture entering the facility from the host rock will evaporate and be removed in the air circulated by the underground ventilation system (Deal and Case, 1987).

\subsubsection{Hydrology of the Rustler-Salado Contact}

The contact zone between the Rustler and Salado Formations at the WIPP site was tested in 20 cased and open drill holes. In Nash Draw and areas immediately west of the site, the contact exists as a dissolution residue capable of transmitting water. Eastward from Nash Draw toward the WIPP site, the amount of dissolution decreases and the transmissivity of this interval decreases. All tests within the boundary of the WIPP site showed very low transmissivities, ranging from $0.9 \times 10^{-5}$ to $0.9 \times 10^{-3}$ meters $^{2} /$ day $\left(3 \times 10^{-5}\right.$ to $3 \times 10^{-3}$ feet $^{2} /$ day) (Mercer, 1983). 


\section{Waste Isolation Pilot Plant \\ Groundwater Protection Management Program Plan \\ DOE/WIPP 96-2162, Rev. 3}

\subsubsection{Hydrology of the Culebra Member}

The Culebra Member of the Rustler Formation has been studied extensively through the site characterization program. Because it is the most transmissive hydrologic unit in the WIPP site area, it is considered the only plausible hydrologic pathway to the accessible environment for any potential contamination.

Mercer (1983) and Mercer and Orr (1977) provide detailed test results for a number of wells completed in the Culebra prior to 1983. Results for both single- and multi-well hydrologic tests are presented by Beauheim (1986b, 1987) and Lambert and Robinson (1983). More recent single- and multi-well test data are presented in Beauheim and Ruskauff (1998). These tests show that the Culebra Dolomite is a fractured, heterogeneous system with varying local anisotropic characteristics. Calculated transmissivities for the Culebra within the WIPP site boundary have a wide range with values between $2.7 \times 10^{-3}$ to approximately 21 meters $^{2} /$ day $\left(9 \times 10^{-2}\right.$ to approximately $69 \mathrm{feet}^{2} /$ day); the majority of the values are less than 0.3 meters $2 /$ day $\left(1 \mathrm{feet}^{2} /\right.$ day $^{2}$ (Beauheim, 1987). Transmissivities generally decrease from west to east across the site area.

Potentiometric surface maps have been constructed using water level data. The Culebra Member is heterogeneous and anisotropic. The flow path of water moving through the Culebra Member is affected by fractures and variable water densities caused by compositional variability. Consequently, the regional direction of flow may have little or no relationship to local flow paths.

An interpretation of flow direction in the Culebra Member is depicted in Figure 2-3. This map shows the regional flow direction of groundwater in the Culebra Member to be generally to the southwest.

\subsubsection{Hydrology of the Magenta Member}

The hydrology of the Magenta Member of the Rustler Formation was tested in 15 cased and open holes at the WIPP site. Transmissivities within the WIPP site study area calculated from the results of these tests range from $0.3 \times 1-2$ to $0.9 \times 10-1$ meters $^{2} /$ day (1x10-2 to $3 \times 10 \mathrm{feet}^{2} /$ day) (Mercer, 1983). More extensive studies of the Magenta Member are scheduled in progress.

\subsubsection{Hydrology of the Dewey Lake Redbeds}

Hydrologic investigations at and near the WIPP site have not identified a continuous zone of saturation within the Dewey Lake Redbeds. Where water is present in the formation, it is generally in small perched or semiperched water tables, and its occurrence is localized (Mercer, 1983). Several wells completed in the Dewey Lake Redbeds are located within several miles of the center of WIPP. These wells include Ranch Well, Barn Well, D-268, Twin Wells, Fairview Well, Unger Well, and Water Quality Sampling Program (WQSP)-6a. One well (Barn Well) sometimes supplies 


\section{Waste Isolation Pilot Plant \\ Groundwater Protection Management Program Plan \\ DOE/WIPP 96-2162, Rev. 3}

drinking water to a ranch house, but is primarily used for livestock. One is used for water quality sampling (WQSP-6a), and the remainder exclusively supply water for livestock. Four intervals of the Dewey Lake Redbeds were tested in drill holes at the WIPP site. Although no saturation was encountered during drilling, 10 wells were completed as observation wells (Ward and Walter, 1983). The data obtained show that there was no development of a zone of saturation in any of these wells.

\subsubsection{Hydrology of the Dockum Group}

At the WIPP site, exploratory holes were drilled through the Gatuña Formation and the Dockum Group. The Gatuña Formation and Dockum Group (inclusive of the Santa Rosa Sandstone) occur within 15 meters (50-80 feet) of the surface and little or no water was encountered in these formations. Only one hole reported a small zone of moisture in the Dockum Group, but observation wells completed in the Dockum Group were dry (Mercer, 1983). Private wells (Comanche and Clifton Wells) do produce potable water from the Dockum Group approximately 16 kilometers (10 miles) east of the center of the WIPP site, and they are used for livestock watering. Recent occurrences of saturation in the Santa Rosa Sandstone within the WLWA are being investigated to determine origin, quantity, and quality of the water.

\subsection{Water Quality}

In addition to the study of site hydrology, surface and groundwater quality has been characterized for two major reasons: (1) to establish, prior to waste emplacement, background levels of naturally occurring inorganic solutes, radionuclides, and potential organic contaminants in water per applicable EPA and/or U.S. DOE Environmental Measurement Laboratory approved procedures; and (2) to define the existing use in the area for ground and surface water as a supply for domestic, industrial, and livestock consumption. Evaluation of WIPP site area hydrology and water quality indicates that existing and potential future use of groundwater and surface water is extremely limited due to non-saturated conditions and very poor water quality. The following subsections describe the quality of the groundwater which occurs in the WIPP area.

\subsubsection{Rustler-Salado Contact}

Mercer (1983) provides data from 20 wells sampled in the WIPP vicinity from the Rustler-Salado contact. The largest concentrations of total dissolved solids (TDS) in the WIPP water-bearing formations are contained in the Rustler-Salado contact.

TDS values range from $79,800 \mathrm{mg} / \mathrm{l}$ (milligrams per liter) in well $\mathrm{H}-07 \mathrm{bl}$ to $480,000 \mathrm{mg} / \mathrm{l}$ in well $\mathrm{H}-01$. Sulfates and chlorides of calcium, magnesium, sodium, and potassium make up the primary dissolved mineral constituents of this brine.

\subsubsection{Culebra Dolomite}

The water quality of the Culebra varies greatly. The TDS value ranges from 3,200 mg/l at well $\mathrm{H}-08 \mathrm{~b}$ to about $291,000 \mathrm{mg} / \mathrm{l}$ at well WIPP-29. These two wells are fairly remote 


\section{Waste Isolation Pilot Plant \\ Groundwater Protection Management Program Plan \\ DOE/WIPP 96-2162, Rev. 3}

from the site, but even at closer proximity to the facility location, a marked variation in the water quality is observed. Well $\mathrm{H}-02 \mathrm{a}$ is located one-half mile west of the center of the site, and has a TDS of $13,500 \mathrm{mg} / \mathrm{l}$ while $\mathrm{H}-15$ which lies one mile east of the center of the site has a TDS of $231,000 \mathrm{mg} / \mathrm{l}$. The chemical constituents consist predominantly of sulfates and chlorides of calcium, magnesium, potassium, and sodium.

\subsubsection{Magenta Dolomite}

The water quality data for the Magenta Dolomite indicate the water is saline to brine, with TDS values ranging between 5,460 to $270,000 \mathrm{mg} / \mathrm{l}$. The predominant dissolved species are sodium, calcium, magnesium, chloride, and sulfate.

\section{$2.8 \quad$ Surface Water}

No surface water occurs in the area of the WIPP site, but surface water bodies within an approximate 40-kilometer (25-mile) radius of the center of the site, such as the Pecos River, the Laguna Grande de la Sal, and livestock tanks which are fed from surface runoff, are sampled as part of the WIPP Environmental Monitoring Plan.

Table 2-1

Wells Sampled As Part of the Detection Monitoring Program

Well Name

WQSP-1

WQSP-2

WQSP-3

WQSP-4

WQSP-5

WQSP-6

WQSP-6a
Water Bearing Unit

Culebra

Culebra

Culebra

Culebra

Culebra

Culebra

Dewey Lake 


\section{Waste Isolation Pilot Plant \\ Groundwater Protection Management Program Plan \\ DOE/WIPP 96-2162, Rev. 3}

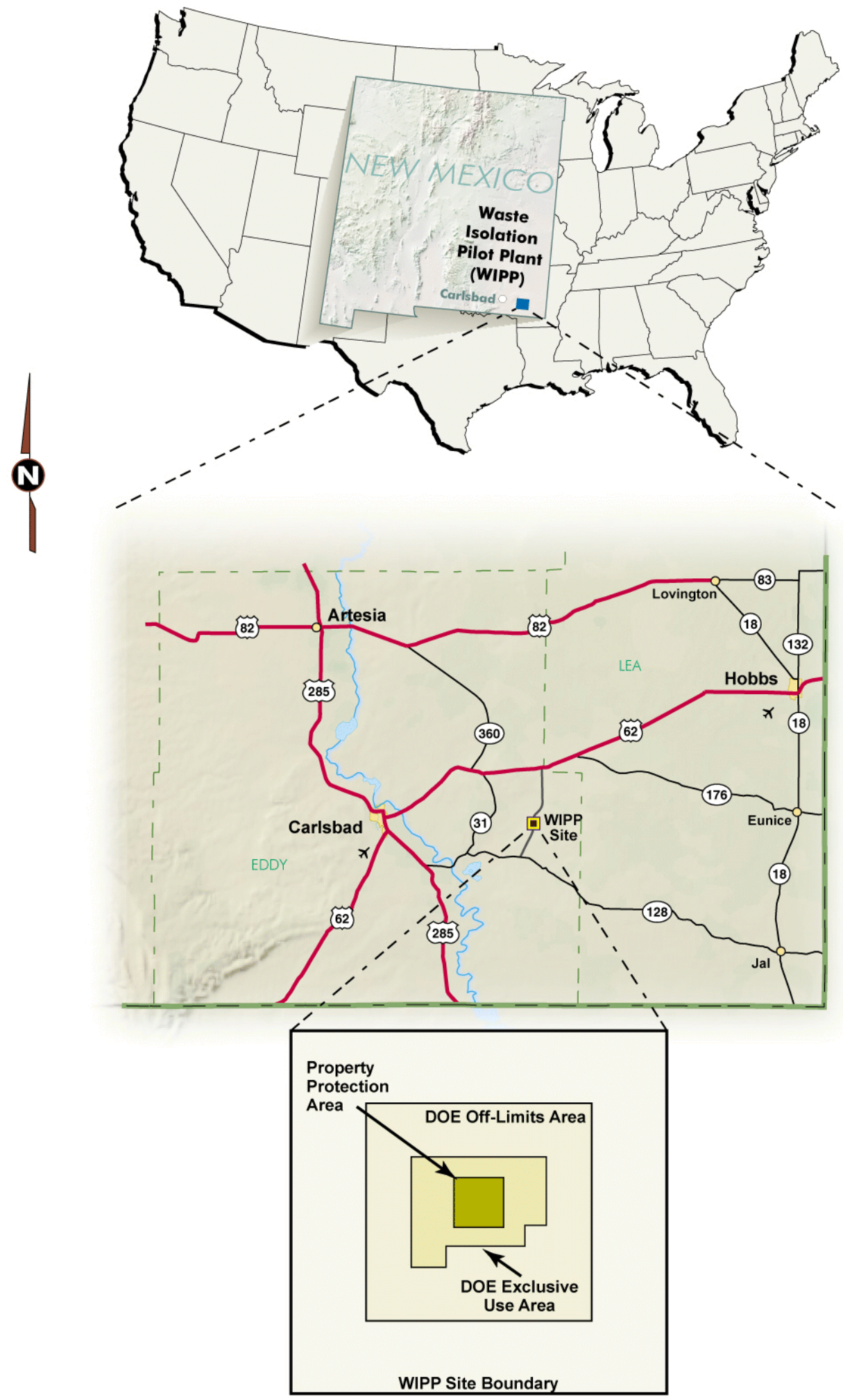

Figure 2-1 - Location of the WIPP Site 


\section{WIPP Facility and Stratigraphic Sequence}

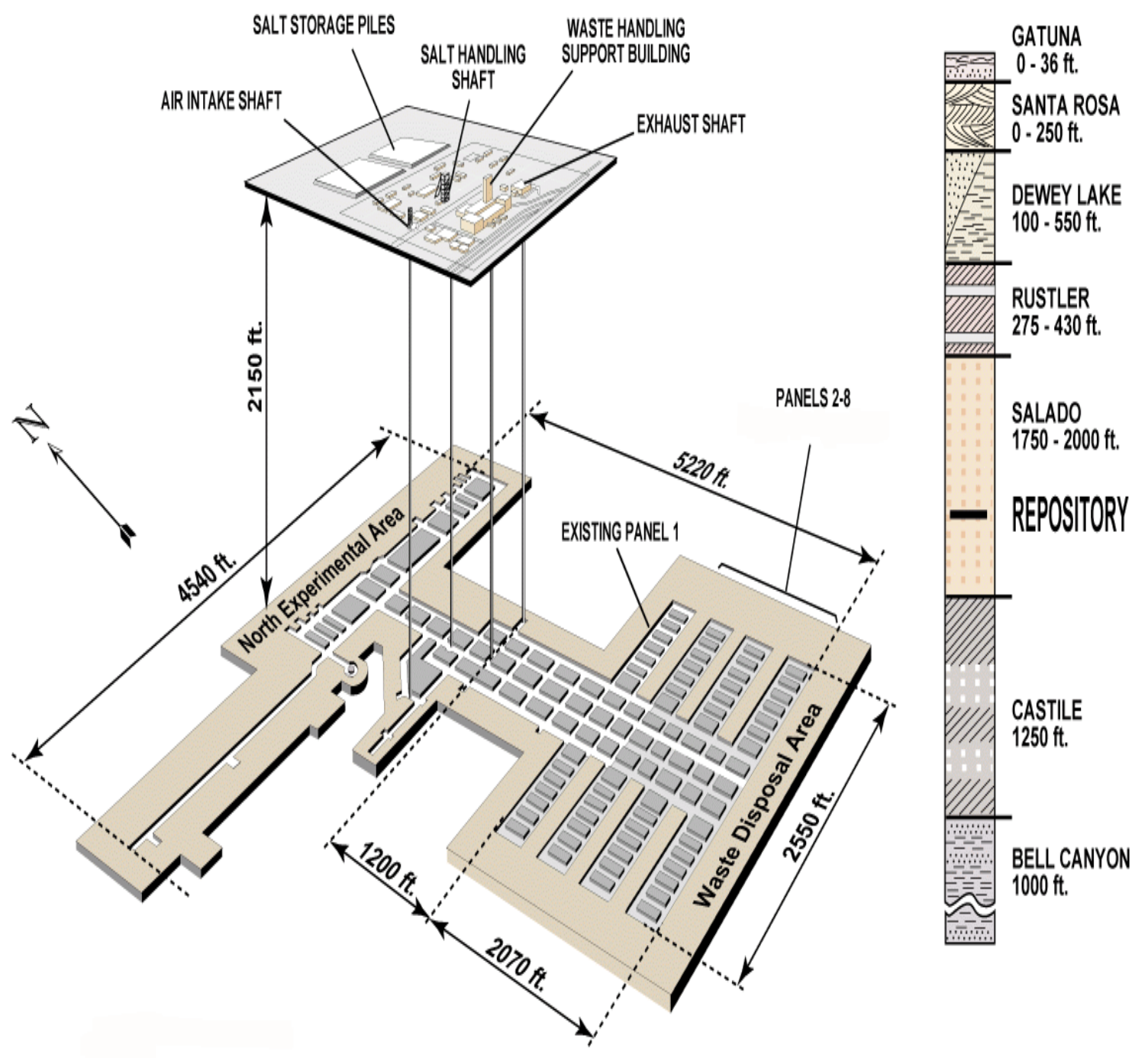

Figure 2-2 - Spatial View of the WIPP Facility 


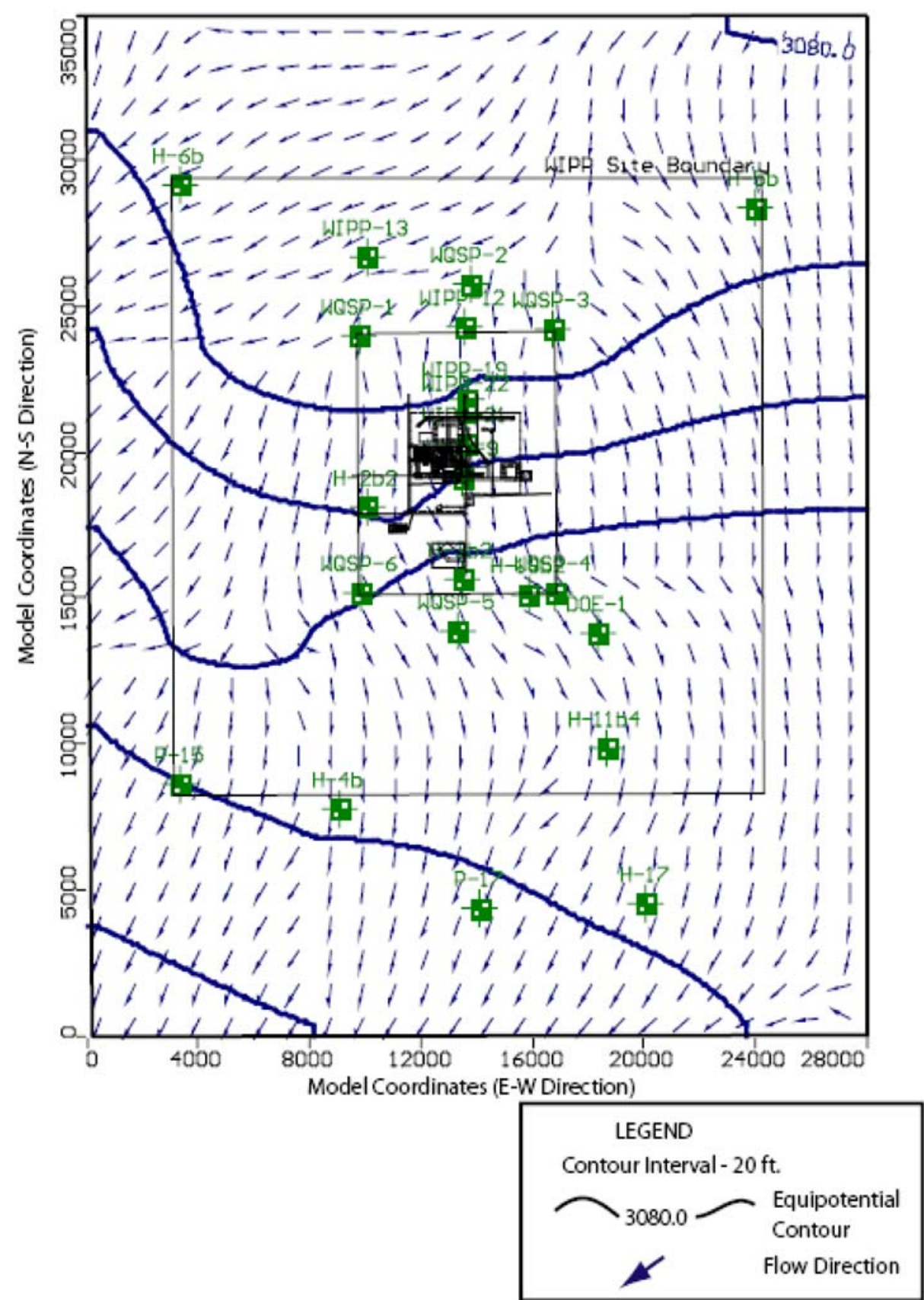

Figure 2-3 - Flow Rate and Direction of Groundwater Across the WIPP Site in the Culebra Formation 


\section{Waste Isolation Pilot Plant \\ Groundwater Protection Management Program Plan \\ DOE/WIPP 96-2162, Rev. 3}

\subsection{GROUNDWATER PROTECTION}

This section describes the WIPP GMP. The GMP sets forth the strategy for groundwater protection at WIPP. The GMP ensures compliance with the WIPP HWFP mandated by 20.4 NMAC, which incorporated applicable sections of 40 CFR Part 264 and 40 CFR Part 265. The GMP also ensures compliance with the WIPP CCA mandated by 40 CFR Part 191 and 40 CFR Part 194.

\subsection{WIPP Groundwater Detection Monitoring Program Overview}

The HWFP Groundwater Detection Monitoring Program (DMP) Plan has been established to define and protect groundwater resources at WIPP. One of the objectives of the WIPP DMP is to establish, by means of groundwater sampling and analysis, an accurate and representative groundwater database that is scientifically defensible and demonstrates regulatory compliance. In addition, the DMP is used to determine background or existing conditions of groundwater quality and quantity, including groundwater surface elevation and direction of flow, around the WIPP facility area.

The WIPP CCA specifically states:

The DOE has addressed the need for monitoring the disposal system during both the preclosure period and the postclosure period in its application for a hazardous waste facility operating permit (see Appendix MON). In its Pre-Closure and Post-Closure (Long-Term) Monitoring Plan (Appendix MON), the DOE incorporates three monitoring programs that will be used to ensure compliance with the hazardous waste regulations of RCRA as implemented by the NMED. These programs include (1) a confirmatory volatile organic compound (VOC) monitoring program to demonstrate that the numerical predictions of $\mathrm{VOC}$ releases are reasonable, (2) a groundwater monitoring program to verify knowledge regarding the characteristics of groundwater flow, including periodic testing for releases from the repository, and (3) a geomechanical monitoring program to support decisions regarding operations and maintenance of underground openings. Only the groundwater program is expected to extend into the 30-year RCRA postclosure period. The EPA has established, as a certification criterion, that the monitoring programs in this application must be complementary with the RCRA programs that the DOE will be required to implement.

This section discusses all groundwater sampling events conducted to meet the requirements of 20.4.1.500 NMAC (incorporating 40 CFR §264.90 through §264.101), as well as 40 CFR Parts 191 and 194 requirements of the CCA. It also ensures that all such data are gathered in accordance with these and other applicable requirements. 


\section{Waste Isolation Pilot Plant \\ Groundwater Protection Management Program Plan \\ DOE/WIPP 96-2162, Rev. 3}

The groundwater quality data generated by monitoring activities will provide a comprehensive background database against which future analytical results can be compared during the DMP.

Groundwater monitoring at WIPP has been historically conducted by several programs including the WIPP Site Characterization Program, the WIPP WQSP, and recently the Groundwater Surveillance Program (GWSP). Groundwater quality and groundwater surface elevation data have been collected by these programs for over 12 years at WIPP. Data from the WQSP wells are used to continually define changes in the area's potentiometric surface and groundwater flow directions to meet the requirements of the CCA. New monitoring wells included in the WIPP GWSP (WQSP wells 1-6a) (Figure 3-1) were constructed to the specifications provided in the RCRA Groundwater Monitoring Technical Enforcement Guidance Document (EPA, 1986) and constitute the HWFP groundwater monitoring network specified in this DMP as required by 20.4.1.500 NMAC (incorporating 40 CFR §264.90 through §264.101). These wells were used to establish background groundwater quality (WIPP RCRA Background Groundwater Quality Baseline Report, DOE/WIPP 98-2285) groundwater surface elevations and flow directions in accordance with 20.4.1.500 NMAC (incorporating 40 CFR §264.97[f] and [g] and §264.98[e]). Justification for the locations of these wells ( 3 upgradient and 4 downgradient) is presented below.

\subsection{Current WIPP DMP}

The WQSP wells 1 through 6a constitute the HWFP DMP for WIPP during detection monitoring as required by 20.4.1.500 NMAC (incorporating 40 CFR §264.90 through $\S 264.101)$. This monitoring plan is a continuation of the WIPP GWSP, and these wells will serve as the monitoring locations during the life of the HWFP DMP (Figure 3-1).

Wells WQSP-1, WQSP-2, and WQSP-3 were located directly upgradient of the WIPP shaft area. The locations of the three upgradient wells were selected to be representative of the flow vectors of groundwater moving downgradient onto the WIPP site. Figure 34 of Davies, 1989, shows a simulation of direction and magnitude of groundwater flow. The upgradient wells were located based on the flow vectors resulting from this model simulation. The original WQSP observation wells, as well as those in the HWFP DMP, have been and will continue to be used as piezometer wells to support collection of groundwater surface elevation and groundwater flow modeling data to demonstrate regulatory compliance (40 CFR Part 191). Well location surveys for each of the seven wells were performed by survey personnel using the State Plane Coordinates-North American Datum Model 27 method. Results of the surveys are on file with the New Mexico Office of the State Engineer.

WQSP-4, WQSP-5, and WQSP-6 were located downgradient of the WIPP shaft area in concert with the flow vectors shown by this model simulation. WQSP-6a was installed in the Dewey Lake Formation at the WQSP-6 location to assess groundwater conditions at this location. All three Culebra downgradient wells (WQSP-4, 5, and 6) were sited based on the greatest velocity magnitude of groundwater flow leaving the shaft area as 


\section{Waste Isolation Pilot Plant \\ Groundwater Protection Management Program Plan \\ DOE/WIPP 96-2162, Rev. 3}

shown on Figure 34 of Davies, 1989, and up-gradient of the WIPP Land Withdrawal Act boundary. WQSP-4 was also specifically located to monitor the zone of higher transmissivity around wells DOE-1 and $\mathrm{H}-11$, which may represent faster flow path away from the WIPP shaft area to the WLWA boundary (DOE, 1996b).

The Culebra has been selected for the focus of the DMP because it is regionally extensive and exhibits the most significant transmissivity of the water-bearing units at WIPP. The Culebra has been extensively studied during past hydrologic characterization programs and was found to be the most likely hydrologic pathway to the accessible environment or compliance point for any potential contamination.

The compliance point is defined in 20.4.1.500 NMAC (incorporating 40 CFR §264.95) as the vertical plane immediately downgradient of the hazardous waste management unit area (i.e., at the downgradient footprint of the WIPP repository). The HWFP Module V specifies the point of compliance as "the vertical surface located at the hydraulically downgradient limit of the underground Hazardous Waste Disposal Units (HWDUs) that extends to the Culebra Member of the Rustler Formation." The HWFP groundwater monitoring network was not installed immediately downgradient of this plane. However, because the underground HWDUs at WIPP are Subpart X units, and due to the relatively unique containment and transport aspects of the site, monitoring at the proposed selected locations will allow for detection of releases prior to release of these contaminants to the general public at the WLWA boundary.

The DMP wells were located to intercept flow vectors downgradient away from the WIPP shafts area based on density corrected potentiometric surfaces. The selected well placement locations are downgradient of the general flow direction from the shaft area. Transport modeling of contaminant migration throughout the Culebra to the Land Withdrawal Act boundary suggests that travel times could be on the order of thousands of years if, under worst case conditions, hazardous constituents could migrate from the sealed repository. If contaminants were to migrate from the disposal facility, they would be detected by the DMP wells located midway between the shafts and WLWA such that samples from wells could detect these contaminants long before they could reach the WLWA boundary.

Potentiometric surfaces and groundwater flow directions defined prior to large-scale pumping in the WIPP area and the excavation of WIPP shafts suggests that flow was generally to the south-southeast from the waste disposal and shaft areas (Mercer, 1983; Davies, 1989). Potentiometric surface maps (December 2004) of the Culebra adjusted for density differences show very similar characteristics (Figure 2-3). WQSP-4, WQSP-5, and WQSP-6 have been located downgradient of the waste emplacement areas according to adjusted potentiometric surfaces.

Potentiometric surfaces that have not been corrected for density differences and that contain transient relics of previous pumping-drawdown events do not reflect accurate natural groundwater flow directions and should not be used to assess the adequacy of groundwater monitoring locations. 


\section{Waste Isolation Pilot Plant \\ Groundwater Protection Management Program Plan \\ DOE/WIPP 96-2162, Rev. 3}

\subsection{Shallow Subsurface Water Monitoring Program}

The SSW occurs beneath the WIPP site at depths less than 100 feet below ground surface (bgs) at the contact between the lower Santa Rosa Formation and the upper Dewey Lake Redbeds Formation. This SSW yields generally less than one gallon per minute in monitoring wells and piezometers and contains high concentrations of TDS and chloride. The origin of this water is believed to be primarily from anthropogenic causes, with some contribution from natural sources. The SSW occurs not only under the WIPP site surface facilities but also to the south as indicated by the recent encounter in drill hole C-2737 (Figure 3-9) about a half mile south of the Waste Handling Shaft. Natural groundwater occurs in the middle part of the Dewey Lake Redbeds Formation at the southern portion of the WIPP site and to the south of the WIPP site. To date there is no indication that the SSW has affected the naturally occurring groundwater in the Dewey Lake Redbeds Formation.

Since discovery of the SSW in the late 1990's, 12 piezometers (PZ-1 through PZ-12) and four wells (C-2505, C-2506, C-2507, and C-2811) have been part of a monitoring program to monitor spatial and temporal changes in SSW water levels and water quality (Figure 3-10). On April 29, 2003, a discharge plan modification application for DP-831 was submitted to the GWQB. The final permit modification was issued to WIPP on December 22, 2003, and contains specific conditions regarding the installation of synthetic liners for the former salt storage area and four storm water retention basins at the site. Additionally, the permit approves the construction design of the new synthetically lined salt storage area and associated evaporation basin.

To comply with the permit conditions WIPP has developed a monitoring plan for the SSW and evaporation basins (WIPP Shallow Subsurface Water and Evaporation Basin Monitoring Plan). This plan consists of quarterly measurement of SSW elevations, semiannual sampling and analysis of SSW wells, and annual sampling and water elevation measurement of evaporation basins. The following represents the monitoring plan to become effective upon issuance of the final permit.

\subsubsection{Water Surface Elevation Monitoring}

The SSW monitoring is performed in selected shallow piezometers and wells to determine spatial and temporal elevation changes. Data are used for groundwater flow direction and flow rate estimates. Data are presented semiannually to GWQB within 120 days of monitoring and sample collection as stipulated in the DP-831 modification dated December 22, 2003.

\subsubsection{Monitoring Network and Data Collection Frequency}

Seventeen SSW wells are monitored. These SSW wells provide adequate coverage of flow conditions in the SSW beneath and adjacent to the WIPP facility. For collection of SSW elevations, all piezometers are measured on a quarterly basis. These include all 


\section{Waste Isolation Pilot Plant \\ Groundwater Protection Management Program Plan \\ DOE/WIPP 96-2162, Rev. 3}

the wells presented in Figure 3-10 and WQSP-6a (Figure 3-9) to the southwest of the WIPP site.

\subsubsection{Surface Elevation Monitoring Methodology}

To obtain an accurate SSW surface elevation measurement, a calibrated water-level measuring device is lowered into a well or piezometer and the depth to water recorded from a known reference point. When using an electrical conductance probe, the depth to water is determined by reading the appropriate measurement markings on the embossed measuring tape when the audible signal is activated at the surface. WIPP procedures specify the methods to be used in obtaining water surface elevation measurements.

\subsubsection{Water Surface Elevation Records and Document Control}

The data management process for SSW surface elevation measurements begins with completion of the field data sheets. Date, time, tape measurement, equipment identification number, calibration due date, initials of the field personnel, and equipment/comments are recorded on the field data sheets. If, for some reason, a measurement is not possible (e.g., a test is under way that prevents entry to the well bore), a notation as to why the measurement was not taken is recorded in the comment section of the field data sheet.

The data are used to calculate SSW surface elevation relative to the mean sea level. The SSW elevations are adjusted to equivalent freshwater heads when pressure density measurements are available.

An electronic database is maintained for all SSW surface elevation data. Data are appended into a yearly file. Upon verification of the data, they are appended into the project database file. A copy of the current project database (through December of the preceding year) is maintained at the facility.

\subsubsection{Water Quality Sampling}

Semiannual water quality samples are obtained from the specified SSW well network and analyzed as described below. Laboratory data are used to identify spatial and temporal changes in SSW chemistry beneath and adjacent to the WIPP site. Results are presented semiannually to GWQB within 120 days of sample collection.

\subsubsection{Sampling Network}

The sampled SSW wells were selected based on the spatial distribution that will provide adequate coverage of chemical characteristics in the SSW beneath and adjacent to the WIPP site. The network was selected based on the variable flow direction, the isopach of the contact between the Santa Rosa and Dewey Lake Redbeds Formations, and localized recharge areas at the facility (i.e., evaporation basins). Based on this 


\section{Waste Isolation Pilot Plant \\ Groundwater Protection Management Program Plan \\ DOE/WIPP 96-2162, Rev. 3}

analysis, the network of eleven piezometers/wells for sampling includes piezometers PZ-1, PZ-5, PZ-6, PZ-7, PZ-9, PZ-10, PZ-11, and PZ-12; monitoring wells C-2507, C-2811 (Figure 3-10); and Water Quality Sampling Program (WQSP)WQSP-6A to the southwest of the WIPP site. Although well WQSP-6A is a part of this monitoring network, it is sampled and analyzed under a different monitoring program plan at WIPP (WQSP) as part of the Hazardous Waste Facility Permit; however, the sampling parameters include those needed to satisfy this monitoring plan.

\subsubsection{Sampling Frequency and Schedule}

Sampling of the SSW monitoring network was historically performed annually. Due to the modified DP-831 requirements, the wells/piezometers are sampled and analyzed semiannually. The sampling intervals are performed during June and December, the first round of sampling was performed in June 2004.

\subsubsection{Sampling Methodology}

The method used on the SSW wells for sampling is the low-flow technique (http://www.nmev.state.nm.us/HWB/data/11-7low-flow\%20final.pdf). Using this technique the amount of drawdown during well purging is minimized through use of a submersible variable speed pump. Attached to the discharge line of the pump assembly is an inline flow through cell where indicator parameters are evaluated using an in situ multimeter, which is capable of simultaneous analysis of $\mathrm{pH}$, conductivity, and temperature. Indicator parameters are taken at least every five minutes during purging until the results stabilize within \pm 10 percent. Specific emphasis is placed on minimizing drawdown during the purging event by monitoring the water levels in five-minute intervals. Samples are collected directly from the discharge line into the specific containers.

\subsubsection{Evaporation Basin Monitoring}

Evaporation basin water sampling and analysis will occur at the Salt Pile Evaporation Pond (SPEP), Salt Storage Extension (SSE), Evaporation Basin A, Pond 1, and Pond 2 (Figure 3-10) to quantify chemical constituents, if any, in surface runoff water. Analytical data are reported in the semiannual DP-831 reports to NMED GWQB.

\subsubsection{Sampling Frequency and Locations}

Water samples are obtained from the SPEP, SSE, Evaporation Basin A, Pond 1, and Pond 2 once per year following a storm event where sufficient quantity of water has collected in the respective basins. Samples are obtained from the edge of the basins at a low elevation point where the water has predominantly been contained. 


\section{Waste Isolation Pilot Plant \\ Groundwater Protection Management Program Plan \\ DOE/WIPP 96-2162, Rev. 3}

\subsubsection{Sampling Methodology}

A representative sample of the water collected in the evaporation basins is obtained for laboratory analysis. Individual samples are collected by submersing the sample container below the water surface and filling it to the appropriate volume. This may be performed by using a sampling boom with the container attached, or by hand grab sampling at the edge of the water body in the evaporation basin. Care is taken to avoid obtaining a sample in areas of high algae growth. Additionally, care is taken to minimize disturbance of bottom sediments. If sediments are inadvertently disturbed, samples are obtained outside of the area of sediment plume. All applicable WIPP procedures are adhered to when performing sample collection.

\subsubsection{Sample Management and Analysis}

\subsubsection{Sample Preservation, Tracking, Packaging, and Transportation}

Some of the chemical constituents to be analyzed in the SSW monitoring program require preservation and special handling techniques. Samples requiring acidification are as specified by the standard method of treatment required for the particular parameter suite. Samples are preserved in accordance with standard methods for the examination of water and wastewater.

The laboratory receiving the samples prescribes the type, the container material type, and the required sample volumes that are collected. This information is recorded on the sample checklist for use by field personnel when samples are being collected. EPA protocol are followed for sample container type, volume, and preservative requirements.

The sample tracking system at WIPP uses uniquely numbered chain-of-custody (CofC) forms and request for analysis (RFA) forms. The primary consideration for storage or transportation is that samples shall be analyzed within the prescribed holding times for the parameters of interest. WIPP procedures provide protocol that ensures proper sample tracking.

Insulated shipping containers packaged with crushed ice or reusable ice packs are used to keep the samples cool during transport to the contract laboratory.

\subsubsection{Sample Documentation and Custody}

To ensure the integrity of samples from the time of collection through the reporting date, sample collection, handling, and custody are documented on a CofC form. Sample custody and documentation for SSW sampling and analysis activities are detailed in WIPP procedures. These procedures are be followed strictly throughout the course of sample collection and analysis. 


\section{Waste Isolation Pilot Plant \\ Groundwater Protection Management Program Plan \\ DOE/WIPP 96-2162, Rev. 3}

Standardized forms used to document samples will include sample identification numbers, sample labels, custody tape, the sample tracking logbooks (STLBs), and the RFA and CofC forms.

\subsubsection{Laboratory Analysis and Analytical Parameters}

Analyses of samples are performed by a commercial laboratory using methods that are consistent with EPA recommended procedures. Table 3-1 presents the analytical parameters for the SSW well sampling program. Table 3-2 presents the analytical parameters for the evaporation basin sampling program

\begin{tabular}{|c|c|c|}
\hline \multicolumn{3}{|c|}{ Shallow Subsurface Water Analytical Parameters } \\
\hline PARAMETER & METHOD ${ }^{* *}$ & COMMENTS \\
\hline Trace Metals & Standard Method 6010 & Filtered only \\
\hline Selenium & Standard Method 6010 & Filtered only \\
\hline Chromium & & \\
\hline General Chemistry & EPA 160.1 & \\
\hline Total Dissolved Solids & EPA 300.0 & \\
\hline Chloride & EPA 300.0 & \\
\hline Sulfate & EPA 300.0 & \\
\hline Nitrate (as Nitrogen) & & \\
\hline Field Indicator Parameters & & \\
\hline Temperature & Field Meter & \\
\hline Conductivity & Field Meter & \\
\hline pH & Field Meter & \\
\hline
\end{tabular}

** Equivalent or superceding methods approved by the EPA.

\begin{tabular}{|c|c|c|}
\hline \multicolumn{3}{|c|}{ Table 3-2 } \\
\hline Evaporation Basins Water Analytical Parameters \\
\hline PARAMETER & METHOD ${ }^{* *}$ & COMMENTS \\
\hline Trace Metals & & Filtered only \\
\hline Selenium & Standard Method 6010 & Filtered only \\
\hline Chromium & Standard Method 6010 & \\
\hline General Chemistry & & \\
\hline Total Dissolved Solids & EPA 160.1 & \\
\hline Chloride & EPA 300.0 & \\
\hline Sulfate & EPA 300.0 & \\
\hline Nitrate (as Nitrogen) & EPA 300.0 & \\
\hline
\end{tabular}

** Equivalent or superceding methods approved by the EPA. 


\section{Waste Isolation Pilot Plant \\ Groundwater Protection Management Program Plan \\ DOE/WIPP 96-2162, Rev. 3}

\subsection{DMP Well Construction Specification}

\subsubsection{WQSP-1}

Well WQSP-1 (Figure 3-2) was drilled between September 13 and 16, 1994, to a total depth of 737 feet (225 meters) bgs. The borehole was drilled through the Culebra and extends 15 feet ( 5 meters) into the Los Medaños Member of the Rustler. The well was drilled to a depth of 693 feet (211 meters) bgs using compressed air as the drilling fluid. The interval from 693 to 737 feet (211 to 225 meters) bgs (the total depth) was drilled using air mist with a foaming agent as the drilling fluid. WQSP-1 was drilled to 695.6 feet (212 meters) bgs using a 9-7/8-in. drill bit and was cored from 695.6 to 737 feet (212 to 225 meters) bgs using a 5-1/4-in. core bit to cut 4-in. diameter core. After coring, WQSP-1 was reamed to 9-7/8 in. in diameter to total depth. WQSP-1 was cased from the surface to 737 feet (224.6 meters) bgs with 5 -in. blank fiberglass casing with in-line 5 -in. diameter fiberglass 0.02 -in. slotted screen across the Culebra interval from 702 to 727 feet (214 to 222 meters) bgs. The annulus between the borehole wall and the casing/screen is packed with sand from 640 to 651 feet (195 to 198 meters) bgs and with 8/16 Brady gravel from 651 to 737 feet (198 to 225 meters) bgs. Based on core log results, the Culebra is located from 699 to 722 feet (213 to 220 meters) bgs.

\subsubsection{WQSP-2}

Well WQSP-2 (Figure 3-3) was drilled between September 6 and 12, 1994, to a total depth of 846 feet ( 257.9 meters) bgs. The borehole was drilled through the Culebra and extends 12.3 feet ( 3.7 meters) into the Los Medaños Member of the Rustler. The well was drilled to a depth of 800 feet (244 meters) bgs with a 9-7/8 in. drill bit using compressed air as the drilling fluid. The interval from 800 to 846 feet (244 to 258 meters) bgs (the total depth) was drilled with a 5-1/4-in. core bit to cut 4-in. diameter core using air mist with a foaming agent as the drilling fluid. After coring, WQSP-2 was reamed to 9-7/8 in. in diameter to total depth. WQSP-2 was cased from the surface to 846 feet ( 258 meters) bgs with 5 -in. blank fiberglass casing with in-line 5 -in. diameter fiberglass 0.02 -in. slotted screen across the Culebra interval from 811 to 836 feet (247 to 255 meters) bgs. The annulus between the borehole wall and the casing/screen is packed with sand from 790 to 793 feet (241 to 242 meters) bgs and with $8 / 16$ Brady gravel from 793 to 846 feet (242 to 258 meters) bgs. Based on core log results, the Culebra is located from 810.1 to 833.7 feet (247 to 254 meters) bgs.

\subsubsection{WQSP-3}

Well WQSP-3 (Figure 3-4) was drilled between October 21 and 26, 1994, to a total depth of 880 feet (268 meters) bgs. The borehole was drilled through the Culebra and extends 10 feet ( 3.1 meters) into the Los Medaños Member of the Rustler. The well was drilled to a depth of 880 feet (268 meters) bgs using compressed air as the drilling fluid. The borehole was cleaned using air mist with a foaming agent. WQSP-3 was drilled to 833 feet (254 meters) bgs using a 9-7/8 in. drill bit and was cored from 833 to 879 feet ( 254 to 268 meters) bgs using a 5-1/4-in. core bit to cut 4 inch diameter core. 


\section{Waste Isolation Pilot Plant \\ Groundwater Protection Management Program Plan \\ DOE/WIPP 96-2162, Rev. 3}

After coring, WQSP-3 was reamed to 9-7/8 in. in diameter to total depth of 880 feet (268 meters) bgs. WQSP-3 was cased from the surface to 880 feet (268 meters) bgs with 5 -in. blank fiberglass casing with in-line 5 -in. diameter fiberglass 0.02 -in. slotted screen across the Culebra interval from 844 to 869 feet (257 to 265 meters) bgs. The annulus between the borehole wall and the casing/screen is packed with sand from 827 to 830 feet (252 to 253 meters) bgs and with 8/16 Brady gravel from 830 to 880 feet (253 to 268 meters) bgs. Based on core log results, the Culebra is located from 844 to 870 feet (257 to 265 meters) bgs.

\subsubsection{WQSP-4}

Well WQSP-4 (Figure 3-5) was drilled between October 5 and 10, 1994, to a total depth of 800 feet (244 meters) bgs. The borehole was drilled through the Culebra and extends 9.2 feet (2.8 meters) into the Los Medaños Member of the Rustler. The well was drilled to a depth of 740 feet (226 meters) bgs with a 9-7/8 in. drill bit using compressed air as the drilling fluid. The interval from 740.5 to 798 feet (225.7 to 243 meters) bgs was cored with a 5-1/4-in. core bit to cut 4-in. diameter core using air mist with a foaming agent as the drilling fluid. After coring, WQSP-4 was reamed to 9-7/8 in. in diameter to total depth of 800 feet (244 meters) bgs. WQSP-4 was cased from the surface to 800 feet (244 meters) bgs with 5 -in. blank fiberglass casing with in-line 5-in. diameter fiberglass 0.02 -in. slotted screen across the Culebra interval from 764 to 789 feet (233 to 241 meters) bgs. The annulus between the borehole wall and the casing/screen is packed with sand from 752 to 755 feet (229 to 230 meters) bgs and with $8 / 16$ Brady gravel from 755 to 800 feet (230 to 244 meters) bgs. Based on core log results, the Culebra is located from 766 to 790.8 feet (233 to 241 meters) bgs.

\subsubsection{WQSP-5}

Well WQSP-5 (Figure 3-6) was drilled between October 12 and 19, 1994, to a total depth of 681 feet (208 meters) bgs. The borehole was drilled through the Culebra and extends into the Los Medaños Member of the Rustler. The well was drilled to a depth of 676 feet (206 meters) bgs using compressed air as the drilling fluid. The borehole was cleaned using air mist with a foaming agent. WQSP-5 was drilled to 648 feet (198 meters) bgs using a 9-7/8 in. drill bit and was cored from 648 to 676 feet (198 to 206 meters) bgs using a 5-1/4-in. core bit to cut 4-in. diameter core. After coring, WQSP-5 was reamed to 9-7/8 in. in diameter to total depth of 681 feet (208 meters) bgs. WQSP-5 was cased from the surface to 681 feet (208 meters) bgs with 5-in. blank fiberglass casing with in-line 5-in. diameter fiberglass 0.02 -in. slotted screen across the Culebra interval from 646 to 671 feet (197 to 205 meters) bgs. The annulus between the borehole wall and the casing/screen is packed with sand from 623 to 626 feet (190 to 191 meters) bgs and with 8/16 Brady gravel from 626 to 681 feet (191 to 208 meters) bgs. Based on core log results, the Culebra is located from 648 to 674.4 feet (198 to 205.6 meters) bgs. 


\section{Waste Isolation Pilot Plant \\ Groundwater Protection Management Program Plan \\ DOE/WIPP 96-2162, Rev. 3}

\subsubsection{WQSP-6}

Well WQSP-6 (Figure 3-7) was drilled between September 26 and October 3, 1994, to a total depth of 616.6 feet (187.9 meters) bgs. The borehole was drilled through the Culebra and extends 9.7 feet (3 meters) into the Los Medaños Member of the Rustler. The well was drilled to a depth of 367 feet (112 meters) bgs using compressed air as the drilling fluid. The interval from 367 to 616 feet (112 to 188 meters) bgs (the total depth) was drilled using brine as the drilling fluid. WQSP-6 was drilled to 568 feet (173 meters) bgs using a 9-7/8 in. drill bit and was cored from 568 to 616 feet (173 to 188 meters) bgs using a 5-1/4-in. core bit to cut 4-in. diameter core. After coring, WQSP-6 was reamed to $9-7 / 8$ in. in diameter to total depth of 616.6 feet (188 meters) bgs. WQSP-6 was cased from the surface to 616.6 feet (188 meters) bgs with 5-in. blank fiberglass casing with in-line 5-in. diameter fiberglass 0.02 -in. slotted screen across the Culebra interval from 581 to 606 feet (177 to 185 meters) bgs. The annulus between the borehole wall and the casing/screen is packed with sand from 567 to 570 feet (173 to 173.7 meters) bgs and with 8/16 Brady gravel from 570 to 616.6 feet (174 to 188 meters) bgs. Based on core log results, the Culebra is located from 582 to 606.9 feet (177 to 185 meters) bgs.

\subsubsection{WQSP-6A}

Well WQSP-6A (Figure 3-8) was drilled between October 31 and November 1, 1994, to a total depth of 225 feet (69 meters) bgs. It is located approximately 100 feet immediately west of WQSP-6. The borehole was drilled through a water-producing zone in the Dewey Lake Redbeds that had been previously encountered while drilling well WQSP-6. The well was drilled to a depth of 225 feet (69 meters) bgs using compressed air as the drilling fluid. The borehole was cleaned using air mist with a foaming agent. WQSP-6A was drilled to 160 feet (49 meters) bgs using a 9-7/8 in. drill bit and was cored from 160 to 220 feet (49 to 67 meters) bgs using a 5-1/4-in. core bit to cut 4-in. diameter core. After coring, WQSP-6A was reamed to 9-7/8 in. in diameter to total depth of 225 feet (69 meters) bgs. WQSP-6A was cased from the surface to 225 feet (69 meters) bgs with 5-in. blank fiberglass casing with in-line 5-in. diameter fiberglass 0.02 -in. slotted screen from 190 to 215 feet (58 to 66 meters) bgs. The annulus between the borehole wall and the casing/screen is packed with sand from 172 to 175 feet (52 to 53 meters) bgs and with 8/16 Brady gravel from 175 to 225 feet (53 to 69 meters) bgs.

\subsection{Monitoring Program Description}

The WIPP DMP has been designed to meet the groundwater monitoring requirements of 20.4.1.500 NMAC (incorporating 40 CFR §264.90 through §264.101) and the CCA. The following sections of the monitoring plan specify the components of the DMP. 


\section{Waste Isolation Pilot Plant \\ Groundwater Protection Management Program Plan \\ DOE/WIPP 96-2162, Rev. 3}

\subsubsection{Monitoring Frequency}

The seven RCRA monitoring wells have been sampled on a semiannual basis since their installation in 1994 to establish background groundwater quality in accordance with 20.4.1.500 NMAC (incorporating 40 CFR §264.97 and §264.98). Background data were collected from 1995 through 1997 and reported in DOE/WIPP 98-2285. The background data were expanded in July 2000 to include ten rounds of sampling instead of five. The data were reported as an addendum to the original report and titled WIPP RCRA Background Groundwater Quality Baseline Update Report. All of the analyses reported in Addendum 1 of the background water quality report were collected prior to the receipt of mixed waste. The expanded baseline is more representative because it is based on twice the population as the original baseline and incorporates the variability produced by different laboratories performing the analysis.

Detection monitoring started with the emplacement of waste and will continue through the post-closure phase as required by 20.4.1.500 NMAC (incorporating 40 CFR §264.90[c]). During detection monitoring, one sample and one sample duplicate are collected semiannually from each well in the HWFP detection monitoring network (Table 3-3). The DMP will continue to collect groundwater quality samples for all seven wells on a semiannual basis during the life of the DMP. Title 20.4.1.500 NMAC (incorporating 40 CFR §264.97[g][2]) provides that an alternate sampling frequency to that provided in 20.4.1.500 NMAC (incorporating 40 CFR §264.98) may be proposed. Given the nature and rate of groundwater flow in the area surrounding WIPP, collecting and analyzing one sample semiannually are protective of human health and the environment because any hazardous constituent leaving the underground disposal facility will not have the potential to migrate beyond the groundwater monitoring network in a one-year time frame.

Groundwater surface elevations are monitored in each of the seven DMP wells on a monthly basis. The groundwater surface elevation in each DMP well are also measured prior to each sampling event. Groundwater surface elevation measurements in the other existing WQSP well sites will also be monitored on a monthly basis (Table 3-3) to supplement the area water-level database and to help define regional changes in groundwater flow directions and gradients. The characteristics of the HWFP DMP (frequency, location) are evaluated if significant changes are observed in the groundwater flow direction or gradient. If any change occurs which could affect the ability of the DMP to fulfill the requirements of 20.4.1.500 NMAC (incorporating 40 CFR Part 264, Subpart F), the proper notifications and actions are taken to comply with applicable permit requirements.

\subsubsection{Analytical Parameters}

The analytes of interest measured to establish background groundwater quality prior to emplacement of waste include all indicator parameters and all other parameters listed in 20.4.1.500 NMAC (incorporating 40 CFR Part 264) Appendix IX. Field measurements of $\mathrm{pH}$, specific conductance (SC), temperature, chloride, Eh (oxidation-reduction 


\section{Waste Isolation Pilot Plant \\ Groundwater Protection Management Program Plan \\ DOE/WIPP 96-2162, Rev. 3}

potential), total iron, and alkalinity were also measured during background sampling (Table 3-4).

The DMP was initiated upon waste emplacement, at which time the semiannual samples were analyzed for the parameters listed in the HWFP (RCRA permit).

Parameters to be analyzed by the contract laboratory such as SC, total dissolved solids, total suspended solids, density, $\mathrm{pH}$, total organic carbon, and total organic halogens were included as indicator parameters because of their universal commonality to groundwater. Parameters such as chloride, alkalinity, calcium, magnesium, and potassium were included as matrix-specific general indicator parameters. Calcium, magnesium, potassium, and chloride may be deleted during detection monitoring, with prior approval of the NMED. Organic and inorganic compounds were chosen because they will occur in the waste to be disposed at the WIPP facility. Additional parameters may be identified through the tentatively identified compound process resulting from a library search performed by the contracted Laboratory. If compounds are identified, these are added to the DMP list, unless omission of these compounds is justified, and this omission is approved by the NMED.

\subsection{Groundwater Sampling}

Groundwater sampling at WIPP has been ongoing since 1985. Prior to 1996, sampling was conducted as a function of site characterization. The goal prior to 1996 was to attain reproducible results from wells that were not completed to regulatory standards for the purpose of characterizing the composition of the groundwater in the vicinity of WIPP.

In 1996 sampling shifted from characterization to detection monitoring. Background data were collected from 1996 to 2000. Beginning in September of 2000, the first round of detection monitoring in compliance with the HWFP was begun. The detection monitoring program is expected to continue in its present format through the post-closure period.

\subsubsection{Groundwater Pumping and Sampling Systems}

The water-bearing units at WIPP are highly variable in their ability to yield water to monitoring wells. The Culebra, the most transmissive hydrologic unit in the WIPP area, exhibits transmissivities that range many orders of magnitude across the site area and is the primary focus of the DMP.

The groundwater pumping and sampling systems used to collect a groundwater sample from the seven DMP wells will provide continuous and adequate production of water so that a representative groundwater sample can be obtained. The wells used for groundwater quality sampling vary in yield, depth, and pumping lift. These factors affect the duration of pumping as well as the equipment required at each well. 


\section{Waste Isolation Pilot Plant \\ Groundwater Protection Management Program Plan \\ DOE/WIPP 96-2162, Rev. 3}

The type of pumping and sampling system used in a well depends primarily on the aquifer characteristics of the Culebra and well construction. The DMP wells have been individually equipped with dedicated submersible pumping assemblies. Each well has a specific type of submersible pump, matched to the ability of the well to yield water during pumping. The down hole submersible pumps are controlled by a variable electronic flow controller to match the production capacity of the formation at each well.

The electronic flow controller allows personnel collecting samples to control the rate of discharge during well purging to minimize the potential for loss of volatiles from the sample. As recommended in the RCRA Groundwater Monitoring Technical Enforcement Guidance Document (EPA, 1986) the wells are purged a minimum of three well bore volumes at a rate that will minimize the agitation of recharge water. This is accomplished by monitoring formation pressure and matching the rate of discharge from the well as nearly as possible to the rate of recharge to the well. WIPP procedures specify the methods used for controlling flow rates and monitoring formation pressure. Well purging requirements are used in conjunction with serial sampling to determine when the groundwater chemistry stabilizes and is therefore representative of undisturbed groundwater.

The DMP wells are cased and screened through the production interval with materials that do not yield contamination to the aquifer or allow the production interval to collapse under stress (high epoxy fiberglass). An electric, submersible pump installation without the use of a packer is used in this instance. The largest amount of discharge from the submersible pump will take place from a discharge pipe. In addition to this main discharge pipe a dedicated sample line, running parallel to the discharge pipe, is also used. Flow through the pipe is regulated on the surface by a flow control valve and/or variable speed drive controller. Cumulative flow is measured using a totalizing flow meter. Flow from the discharge pipe is routed to a discharge tank for disposal.

The dedicated sampling line is used to collect the water sample that undergo analysis. By using a dedicated sample line, the water is not contaminated by the metal discharge pipe. The sample line branches from the main discharge pipe a few inches above the pump. Flow from the sample line is routed into the sample collection area. Flow through the sample collection line is regulated by a flow-control valve. The sample is insulated at the surface to minimize temperature fluctuations.

\subsubsection{Pressure Monitoring Systems}

The DMP wells do not require the installation of a packer because sample biases due to well construction deficiencies are not present. However, pressures are monitored using down hole automatic air line bubblers in the formation to maintain the water level above the pump intake. Pressure transducers may be used in line with bubblers to provide continual electronic monitoring through data acquisition systems. WIPP procedures provide instructions for monitoring formation pressure using automatic airline bubblers in conjunction with pressure transducers and data acquisition systems. 


\section{Waste Isolation Pilot Plant \\ Groundwater Protection Management Program Plan \\ DOE/WIPP 96-2162, Rev. 3}

The mobile field laboratory provides a work place for conducting field sampling and analyses. The laboratory is positioned near the wellhead, climate controlled, and contains the necessary equipment, reagents, glassware, and deionized water for conducting the various field analyses.

\subsection{Sampling Overview}

Two types of water samples are collected: serial samples and final samples. Serial samples are taken at regular intervals and analyzed in the mobile field laboratory for various physical and chemical parameters (called field indicator parameters). The serial sample data are used to determine whether the sample is representative of undisturbed groundwater as a direct function of the stabilization of field indicator parameters and the volume of the water being pumped from the well. Interpretation of the serial sampling data enables a determination of when conditions representative of undisturbed groundwater are attained in the pumped groundwater. Final samples are collected when the serially sampled field indicator parameters have stabilized and are therefore representative of undisturbed groundwater.

\subsubsection{Serial Samples}

Serial sampling is the collection of sequential samples for the purpose of determining when the groundwater chemistry stabilizes and is therefore representative of undisturbed groundwater.

A serial sample is considered representative of undisturbed groundwater when the majority of field indicator parameter measurements have stabilized within \pm 5 percent of the average of analytical results for the field indicator parameter from the background groundwater quality for each DMP well.

Nonstabilization of one or two field indicator parameters attributable to matrix interferences, instrument drift, or other unforeseen reasons will not preclude the collection of final samples, provided the volume of purged water exceeds three well bore volumes. Final samples collected, when field indicator parameters were not stabilized, are reported in the operating record, and an explanation of why the sample was collected when field indicator parameters were not stabilized are provided.

Serial samples are collected and analyzed to detect and monitor the chemical variation of the groundwater as a function of the volume of water pumped. Once serial sampling begins, the frequency at which serial samples are collected and analyzed are reviewed periodically, but are performed a minimum of three times during a sampling round.

The appropriate field methods to identify stabilization of the following field indicator parameters: chloride, divalent cations (hardness), alkalinity, total iron, $\mathrm{pH}, \mathrm{Eh}$, temperature, SC, and specific gravity are used. Protocols for collection of serial samples are specified in WIPP procedures. 


\section{Waste Isolation Pilot Plant \\ Groundwater Protection Management Program Plan \\ DOE/WIPP 96-2162, Rev. 3}

The three field indicator parameters of temperature, Eh, and $\mathrm{pH}$ are determined by either an "in-line" technique, using a self-contained flow cell, or an "off-line" technique, in which the samples are collected from a sample line at atmospheric pressure. The iron, divalent cation, chloride, alkalinity, SC, and specific gravity samples are collected from the nylon sample line at atmospheric pressure. Because of the lack of sophisticated weights and measures equipment available for field density assessments, field density evaluations are expressed in terms of specific gravity, which is a unitless measure. Density is expressed as unit weight per unit volume.

New polyethylene containers are used to collect the serial samples from the sample line. Serial sampling water collected for solute and SC determinations are filtered through a 0.45 micrometers membrane filter using a stainless-steel, in-line filter holder. Filtered water is used to rinse the sample bottle prior to serial sample collection. Unfiltered groundwater is used when determining temperature, $\mathrm{pH}$, Eh, and specific gravity. Sample bottles are properly identified and labeled.

The filtered sample collected for solute analyses are analyzed immediately for iron and alkalinity because these two solution parameters are extremely sensitive to changes in the ambient water-sample pressure and temperature. A sample and duplicate of filtered water are collected and analyzed for solute parameters (alkalinity, chloride, divalent cations, and iron). Temperature, $\mathrm{pH}$, and Eh, when not measured in a flow cell, are measured at the approximate time of serial sample collection. These samples are collected from the unfiltered sample line.

Samples to be analyzed for chloride and divalent cations (after preservation with nitric acid and stored at 4 degrees Celsius $\left({ }^{\circ} \mathrm{C}\right.$ ) may be stored for one week prior to analysis with confidence that the analytical results will not be altered.

Upon completion of the collection of the last serial sample suite, the serial sample bottles accrued throughout the duration of the pumping of the well are discarded. No serial sample bottles are reused for sampling purposes of any sort. However, serial samples may be stored for a period of time depending upon the need.

\subsubsection{Final Samples}

The final sample is collected once the measured field indicator parameters have stabilized.

A serial sample also is collected and analyzed for each day of final sampling to ensure that samples collected for laboratory analysis are still representative of stable conditions. Sample preservation, handling, and transportation methods maintain the integrity and representativeness of the final samples.

Prior to collecting the final samples, the collection team considers the analyses to be performed so that proper shipping or storage containers can be assembled. Other 


\section{Waste Isolation Pilot Plant \\ Groundwater Protection Management Program Plan \\ DOE/WIPP 96-2162, Rev. 3}

considerations include sample containers, volumes, and holding times for laboratory samples collected as part of the DMP.

The monitoring system uses dedicated pumping systems and sample collection lines from the sampled formation to the well head. Nondedicated sample collection lines from the well head to the sample collection area are discarded after each use.

Sample integrity is ensured through appropriate decontamination procedures. Laboratory glassware is washed after each use with a solution of nonphosphorus detergent and deionized (DI) water and rinsed in DI water. Sample containers are new, certified-clean containers that are discarded after one use. Groundwater surface elevation measurement devices are rinsed with fresh water after each use. Nondedicated sample collection manifold assemblies are rinsed with two gallons of fresh water, then rinsed with five gallons of 5 percent nitric acid solution and rinsed with five gallons of DI water after each use. The exposed ends are capped off during storage. Prior to the next use of the sampling manifold, it is rinsed a second time with DI water and a blank rinsate sample is collected to verify decontamination.

Water samples are collected at atmospheric pressure using either the filtered or unfiltered sampling lines branching from the main sample line. Detailed protocols, in the form of procedures, assure that final samples are collected in a consistent and repeatable fashion.

Final samples are collected in the appropriate type of container for the specific analysis to be performed. The samples are collected in new and unused glass and plastic containers. For each parameter analyzed, a sufficient volume of sample is collected to satisfy the volume requirements of the analytical laboratory (as specified by laboratory Standard Operating Procedures [SOPs]). This includes an additional volume of sample water necessary for maintaining quality control $(Q C)$ standards. All final samples are treated, handled, and preserved as required for the specific type of analysis to be performed. Details about sample containers, preservation, and volumes required for individual types of analyses are found in the applicable procedures generated, approved, and maintained by the contract analytical laboratory.

Before the final sample is taken, all plastic and glass containers are rinsed with the pumped groundwater, either filtered or unfiltered, dependent upon analysis protocol. When the rinsing procedure is completed, the final sample is collected.

Final nonradiological samples are sent to contract laboratories and analyzed for general chemistry. Radionuclides and selected VOCs that are specific to the waste anticipated to arrive at WIPP are analyzed by WIPP laboratories.

Duplicates of the final sample are provided to WIPP oversight agencies as requested by the CBFO or the NMED. 


\section{Waste Isolation Pilot Plant \\ Groundwater Protection Management Program Plan \\ DOE/WIPP 96-2162, Rev. 3}

Resulting wastes are disposed of in accordance with the WTS Hazardous and Universal Waste Management Plan, WP 02-RC.01.

\subsubsection{Sample Preservation, Tracking, Packaging, and Transportation}

Many of the chemical constituents measured in accordance with the DMP are not chemically stable and require preservation and special handling techniques.

Samples requiring acidification are treated with either high purity hydrochloric acid, nitric acid, or sulfuric acid (ULTREX or equivalent), depending upon the standard method of treatment required for the particular parameter suite or as requested by contract laboratory SOPs.

The contract laboratory receiving the samples uses procedures that prescribe the type and amount of preservative, the container material type, and the required sample volumes that shall be collected. This information is recorded on the Final Sample Checklist for use by field personnel when final samples are being collected. Table 4-1 in the EPA RCRA Groundwater Monitoring Technical Enforcement Guidance Document (EPA, 1986), is followed if laboratory SOPs do not specify sample container, volume, or preservation requirements.

The sample tracking system at WIPP uses uniquely numbered CofC forms and RFA forms. The primary consideration for storage or transportation is that samples be analyzed within the prescribed holding times for the parameters of interest. WIPP procedures provide instructions to ensure proper sample tracking protocol.

Insulated shipping containers packaged with crushed ice or reusable ice packs is used to keep the samples cool during transport to the contract laboratory. Holding times for specific analytical parameters may require samples to be shipped by express air freight. The coolers shipped by express air freight are packaged to meet U.S. Department of Transportation and International Air Transportation Association commercial carrier regulations.

\subsubsection{Sample Documentation and Custody}

To ensure the integrity of samples from the time of collection through reporting date, sample collection, handling, and custody are documented.

Sample custody and documentation for environmental monitoring sampling and analysis activities are detailed in WIPP procedures. These procedures are followed strictly throughout the course of each sample collection and analysis event.

Standardized forms used to document samples include sample identification numbers, sample labels, custody tape, the STLBs, and the CofC and RFA forms. The forms are briefly defined in the following subsections. 


\section{Waste Isolation Pilot Plant \\ Groundwater Protection Management Program Plan \\ DOE/WIPP 96-2162, Rev. 3}

All sample documentation are completed for each sample and reviewed by Environmental Monitoring and Hydrology staff for completeness and accuracy.

\subsubsection{Sample Numbers and Labels}

A unique sample identification number is assigned to each sample sent to the laboratory for analysis prior to sample collection.

The sample identification numbers is used to track the sample from the time of collection through data reporting. Every sample container sent to the laboratory for analysis is identified with a label affixed to it. Sample label information is completed in permanent, indelible ink and contains the following information: sample identification number with sample matrix type; sample location; analysis requested; time and date of collection; preservative(s), if any; and the sampler's name or initials.

\subsubsection{Custody Seals}

Custody seals are used to detect unauthorized sample tampering from collection through analysis.

The custody seals are adhesive-backed strips that are destroyed when removed or when the container is opened. The seal is dated, initialed, and affixed to the sample container in such a manner that it is necessary to break the seal to open the container. Seals are affixed to sample containers in the field immediately after collection. Upon receipt at the laboratory, the laboratory custodian inspects the seal for integrity; a broken seal invalidates the sample.

\subsubsection{Sample Tracking Logbook}

An STLB form is completed for each sample collected. The STLB includes the following information: CofC number; RFA number; date sample(s) were sent to the lab; laboratory name; acknowledgment of receipt or comments; well name and round number. Sample codes indicate the well location; the geologic formation where the water was collected from, the sampling round number; and the sample number. The code is broken down as follows:

\section{WQ6 ${ }^{1} \mathrm{C}^{2} \mathrm{R} 2^{3} \mathrm{~N} 1^{4}$}

${ }^{1}$ Well identification (e.g., WQSP-6 in this case)

${ }^{2}$ Geologic formation (e.g., the Culebra in this case)

${ }^{3}$ Sample round number (Round 2)

${ }^{4}$ Sample number (N1)

To distinguish duplicate samples from other samples, a "D" is added as the last digit to signify a duplicate. STLB information is completed in the field by the sampling team and 


\section{Waste Isolation Pilot Plant \\ Groundwater Protection Management Program Plan \\ DOE/WIPP 96-2162, Rev. 3}

checked. When samples are shipped, the STLB remains in the custody of Environmental Monitoring and Hydrology for sample tracking purposes.

\subsubsection{Request for Analysis and Chain-of-Custody Forms}

The RFA and CofC forms are completed during or immediately following sample collection and accompany the sample through analysis and disposal.

The RFA and CofC forms are signed and dated each time the sample custody is transferred. A sample is considered to be in a person's custody if:

- $\quad$ The sample is in his or her physical possession;

- $\quad$ The sample is in his or her unobstructed view; and/or

- $\quad$ The sample is placed, by the last person in possession of it, in a secured area with restricted access.

During shipment, the carrier's air bill number serves as custody verification. Upon receipt of the samples at the laboratory, the laboratory sample custodian acknowledges possession of the samples by signing and dating the RFA and CofC forms. The completed original (top page) of the RFA and CofC forms are returned to Environmental Monitoring and Hydrology with the laboratory analytical report and becomes part of the permanent record of the sampling event. The RFA and CofC forms also contain specific instructions to the laboratory for sample analysis, potential hazards, and disposal instructions.

\subsection{Laboratory Analysis}

Analyses of samples are performed by a commercial laboratory. Methods are specified in procurement documents and are selected to be consistent with EPA recommended procedures in SW-846, Test Methods for Evaluating Solid Waste, Physical/Chemical Methods (EPA, 1996). Additional detail on analytical techniques and methods are given in laboratory SOPs.

WTS has established criteria for laboratory selection, including the stipulation that the laboratory follow the procedures specified in SW-846 and that the laboratory follow EPA protocols. The selected laboratory demonstrates, through laboratory SOPs, that it follows appropriate EPA SW-846 requirements and the requirements specified by the EPA protocols. The laboratory also provides documentation to WIPP describing the sensitivity of laboratory instrumentation. This documentation is retained in the facility operating record and is available for review upon request by an authorized agency. Instrumentation sensitivity needs to be considered because of regulatory requirements governing constituent concentrations in groundwater and the complexity of brines associated with the WIPP repository.

Once the initial qualification criteria, as specified above, have been met, a laboratory is selected based upon competitive bid. The selected laboratory performs analytical work 


\section{Waste Isolation Pilot Plant \\ Groundwater Protection Management Program Plan \\ DOE/WIPP 96-2162, Rev. 3}

for the DMP for a predetermined period of time, as specified in the contract between the WTS and the selected laboratory. As this period of performance comes to an end, a new laboratory selection/competitive bid process is initiated in accordance with the DMP.

The same or a different laboratory may be selected for the new contract period. The SOPs for the laboratory currently under contract are maintained in a file in the operating record. An initial set of SOPs is provided to the NMED for information purposes along with any SOP updates on an annual basis.

Data validation is performed by Environmental Monitoring and Hydrology. Data validation results are documented on an Approval/Variation Request (AR/VR) form. If no discrepancies are found in the data, the AR/VR form is signed and the approved box checked. However, if discrepancies are found, the AR/VR form is signed, the disapproved or approved-on-condition box checked, and the form returned to the designated staff member accompanied by an attached report discussing the data validation results, any anomalies, and resolutions. Copies of the data validation report are kept on file in the Environmental Monitoring and Hydrology records for review upon request by the NMED.

\subsection{Statistical Analysis of Laboratory Data}

As required by 20.4.1.500 NMAC (incorporating 40 CFR §264.97 and §264.98), data collected to establish background groundwater quality and as part of the DMP are evaluated using appropriate statistical techniques.

The following specifies the statistical analysis to be performed in accordance with the DMP. Statistical analysis of DMP data conform to EPA guidance, Statistical Analysis of Groundwater Monitoring Data at RCRA Facilities (EPA, 1989), Statistical Analysis of Groundwater Monitoring Data at RCRA Facilities, Addendum to Interim Final Guidance (EPA, 1992), and DOE/EH-0173T.

\subsubsection{Temporal and Spatial Analysis}

Environmental parameters vary with space and time. The effect of one or both of these two factors on the expected value of a point measurement could be statistically evaluated through spatial analysis and time series analysis, however, these methods often require extensive sampling efforts that may exceed the practical limits of the DMP sampling procedures.

Time series analysis plays the most important role in data analysis for the DMP. Parameters are reported as time series, either in tabular form or as time plots. For key time series parameters, these plots are in the form of control charts on which control levels are identified based on preoperational database, fixed standards, control location databases, or other standards for comparison. Where significant seasonal changes in the expected value of the parameter are identified in the preoperational database or in 


\section{Waste Isolation Pilot Plant \\ Groundwater Protection Management Program Plan \\ DOE/WIPP 96-2162, Rev. 3}

the control locations, corrections in the control levels which reflect the seasonal change are made and documented.

\subsubsection{Distributions and Descriptive Statistics}

For data sets which include more than ten data points that are homogeneous in space and time (including seasonal homogeneity) and have less than 10 percent missing data, a test for conformance to the normal distribution are performed.

The test for normality of the data is performed in accordance with the methodologies presented in Statistical Analysis of Groundwater Monitoring Data at RCRA Facilities, Addendum to Interim Final Guidance (EPA, 1992). Examples of tests performed on the data are Shapiro-Wilk Test or Kolmogorov-Smirnov Test at the 95 percent confidence level, there is only a one-in-twenty chance of falsely identifying the distribution as normal when it really is not.

If normality is not met, the data are log-transformed (or transformed using a suitable mathematical transformation [e.g., square root]) and retested for normality. If the transformed data fit is a normal distribution, the original data are accepted as having lognormal or an otherwise mathematically transformed normal distribution. If normality is still not found, two courses may be taken. One is to continue to test the fit to standard families of distributions, such as the gamma, beta, and Weibull, with proper modifications to subsequent analyses based on these results. The other course is to use nonparametric methods of data analysis. Nonradiological data sets with greater than 15 percent nondetect are automatically treated as nonparameteric distributions.

For data sets smaller than ten, but homogeneous and complete, the lognormal distribution are assumed. Data sets with more than 10 percent missing data are analyzed using nonparametric methods. Nonhomogeneous data sets are subdivided into homogeneous sets and each of these analyzed individually.

Descriptive statistics are calculated for each homogeneous data set. At a minimum, these include a central value and a range of variation. The central value is the arithmetic mean of the untransformed data if the data are not censored at either end. If the data are censored, either a trimmed mean or the median are used as the central value (which may be within the censored range). If the data set is greater than ten and is uncensored, the standard deviation is calculated and used as a basis for the reported range in variation. If these criteria are not met, the range between the 0.25 and 0.75 cartelist is used. Radiological normally distributed data with a small number of extreme or less than detectable values, the arithmetic mean is the estimator of central tendency. When a data set contains large extreme values, the median, which is less sensitive to extreme values than the mean, is used to summarize the data. All of the actual values, including those that are negative, are included in the statistical analysis for radiological data. Radiological data also are transformed to approximate a normal distribution before the central values are calculated. Most often a log transformation normalizes environmental data. 


\section{Waste Isolation Pilot Plant \\ Groundwater Protection Management Program Plan \\ DOE/WIPP 96-2162, Rev. 3}

\subsubsection{Data Anomalies}

Data anomalies include data points reported as being below the limit of detection (LD) or otherwise censored over a specific range of values, missing data points occurring randomly in the data set, and outliers that cannot be ascribed to a known source of variation.

Whenever possible, sample values which are reported below detection limits are incorporated into the database for statistical analysis. When values are not available, alternative methods of analysis, as specified in previous sections, are used. In particular, the use of nonparametric statistics are required.

Missing data points comprising less than 10 percent of the data set do not significantly affect data analyses. Results based on data in which more than 10 percent is missing are identified as such at the time of reporting. The potential effect of missing data is considered when the majority of the data are missing from a discrete time span.

Formal testing for outliers is done in accordance with EPA guidance. The methodologies specified in Section 8.2 of the Statistical Analysis of Groundwater Monitoring Data at RCRA Facilities (EPA, 1989) are used to check for outliers.

If an outside source of variation is not identified to account for outliers in a data set, it is included in the data set and all subsequent analyses. If the inclusion of such outliers is found to affect the final results of the analyses significantly, both results (with and without outliers) are reported. Radiological outliers are tested with respect to the mean or median of the entire data set for outliers. Trend analyses on radiochemical data are performed by comparing the results for the current year with the results of last several years to identify changes or inconsistencies in the results. Radiological data also are plotted in time series for historical comparison. Data points falling outside \pm 3 standard deviations could be considered outliers. Time plot and other yearly or seasonal trends in the data should be considered to reject/accept outliers.

\subsection{Comparisons and Reporting}

Prior to waste receipt, measurements were made of each background groundwater quality parameter and constituent specified in Table 3-4 at every DMP groundwater monitoring well during each of the ten background sampling events.

If any background groundwater quality parameter or constituent had not been measured prior to waste receipt (such as newer, needed parameters), measurements are made for those parameters or constituents in hydraulically upgradient DMP groundwater monitoring wells for a sequence of four sampling events.

Following completion of the four sampling events, the arithmetic mean and variance shall then be calculated by the field supervisor or designee for each well. These measurements will then serve as a background value against which statistical values for 


\section{Waste Isolation Pilot Plant \\ Groundwater Protection Management Program Plan \\ DOE/WIPP 96-2162, Rev. 3}

subsequent sampling events during detection monitoring are compared. Statistical analysis and comparison are accomplished using one of the five statistical tests specified in 20.4.1.500 NMAC (incorporating 40 CFR §264.98[h]), which may include Cochran's Approximation to the Behrens-Fisher students' t-test at the 0.01 level of significance, or control charting (described in Appendix IV to 20.4.1.500 NMAC (incorporating 40 CFR Part 264).

If the comparisons show a significant increase at any monitoring site (as defined in 20.4.1.500 NMAC (incorporating 40 CFR §264.98[f]), the well shall be resampled and an analysis performed as soon as possible, in accordance with 20.4.1.500 NMAC (incorporating 40 CFR §264.98[g][2]) (WIPP HWFP Requirement V.J.3.b). The results of the statistical comparison are reported annually in the annual Site Environmental Report (SER), and are reported to the NMED as stated in Module V, Section V.J.3 of the Final WIPP Hazardous Waste Permit and as required under 20.4.1.500 NMAC (incorporating 40 CFR §264.98[g]).

\subsubsection{Laboratory Data Reports}

Laboratory data are provided in electronic and hard copy reports.

Laboratory data reports are forwarded to Environmental Monitoring and Hydrology and the NMED and contain the following information for each analytical report:

- $\quad$ A brief narrative summarizing laboratory analyses performed, date of issue, deviations from the analytical method, technical problems affecting data quality, laboratory quality checks, corrective actions (if any), and the project manager's signature approving issuance of the data report.

- $\quad$ Header information for each analytical data summary sheet including: sample number and corresponding laboratory identification number; sample matrix; date of collection, receipt, preparation and analysis; and analyst's name.

- $\quad$ Analytical parameter, analytical result, reporting units, reporting limit, analytical method used.

- $\quad$ Results of QC sample analyses for all concurrently analyzed QC samples.

\subsubsection{Statistical Analysis and Reporting of Results}

Analytical results from semiannual groundwater sampling activities are compared and interpreted through generation of statistical analyses and control charting as specified in Section L-4e of the WIPP HWFP.

Statistical analyses are performed; and the results included in the SER in summary form, and provided to the NMED as specified in Permit Module V (WIPP HWFP Section V.J.2). 


\section{Waste Isolation Pilot Plant \\ Groundwater Protection Management Program Plan \\ DOE/WIPP 96-2162, Rev. 3}

\subsubsection{Annual Site Environmental Report}

Data collected from this DMP are reported to the NMED as specified in Permit Module V, and to the Environmental Monitoring and Hydrology manager and the NMED in the SER. The SER includes all applicable information that may affect the comparison of background groundwater quality and groundwater surface elevation data through time. This information includes, but is not limited to:

- Well configuration changes that may have occurred from the time of the last measurement (i.e., plug installation and removal, packer removal and reinstallation, or both; and the type and quantity of fluids that may have been introduced into the test wells).

- $\quad$ Any pumping activities that may have taken place since publication of the last annual report (i.e., groundwater quality sampling, hydraulic testing, and shaft installation or grouting activities).

\subsection{Groundwater Surface Elevation Measurement}

Groundwater surface elevations are measured in each available well bore in the WIPP groundwater level monitoring program (WLMP) either monthly or on a quarterly basis. Groundwater surface elevations in each of the DMP wells are also measured prior to each sampling event (Table 3-3).

\subsubsection{Groundwater Surface Elevation Monitoring Methodology}

The WLMP is a subprogram of the DMP. The quality assurance activities of the WLMP are in strict accordance with the WTS Quality Assurance Program Description (QAPD) (WP 13-1), and the quality assurance implementing procedures specific to groundwater surface elevation monitoring.

Groundwater surface elevation monitoring is in progress now and will continue through the post-closure care period. This section of the plan addresses the activities of the WLMP during the preoperational and operational phases of WIPP.

Collection of groundwater surface elevation data is required by 20.4.1.500 NMAC (incorporating 40 CFR §264.97[f]) and 40 CFR Part 191. These data also provide:

- Data collection as required by the Environmental Monitoring Plan.

- A means to fulfill commitments made in the Final Environmental Impact Statement (FEIS).

- $\quad$ A means to comply with future groundwater inventory and monitoring regulations. 


\section{Waste Isolation Pilot Plant \\ Groundwater Protection Management Program Plan \\ DOE/WIPP 96-2162, Rev. 3}

- Input for making land use decisions (i.e., designing long-term active and passive institutional controls for the site).

- $\quad$ Assistance in understanding any changes to readings from the water-pressure transducers installed in each of the shafts to monitor water conditions behind the liners.

- $\quad$ An understanding of whether or not the horizontal and vertical gradients of flow are changing over time.

The objective of the WLMP is to extend the documented record of groundwater surface elevation fluctuations in the Culebra and Magenta Members of the Rustler in the vicinity of the WIPP facility and to meet the requirements of 20.4.1.500 NMAC (incorporating 40 CFR §264.97[f]) and 40 CFR Part 191, "Performance Assessment."

Groundwater surface elevation data are collected from each well of the HWFP DMP. Groundwater surface elevation data also are collected from other Culebra wells, as well as monitoring wells completed in other water-bearing zones overlying and underlying the WIPP repository horizon when access to those zones is possible (Figure 3-9). This includes, but is not limited to, the Bell Canyon, the Forty-niner, the contact zone between the Rustler and Salado, and the Dewey Lake.

Groundwater surface elevation measurements are taken monthly in at least one accessible completed interval at each available well pad. At well pads with two or more wells completed in the same interval, quarterly measurements are taken in the redundant wells.

Groundwater surface elevation measurements are taken monthly at each of the seven DMP wells, as well as prior to each sampling event. If a cumulative groundwater surface elevation change of more than two feet is detected in any DMP well over the course of one year which is not attributable to site tests or natural stabilization of the site hydrologic system, notification is made to the NMED in writing and discuss the origin of the changes in the report specified in Permit Module V. Abnormal, unexplained changes in groundwater surface elevation may indicate changes in site recharge/discharge which could affect the assumptions regarding DMP well placement and constitute new information as specified in 20.4.1.900 NMAC (incorporating 40 CFR $\S 270.41[a][2])$.

Groundwater surface elevation monitoring will continue through the post-closure care period. The frequency of monitoring may be temporarily increased to effectively document naturally occurring or artificial perturbations that may be imposed on the hydrologic systems at any point in time. This is conducted in selected key wells by increasing the frequency of the manual groundwater surface elevation measurements or by monitoring water pressures with the aid of electronic pressure transducers and remote data-logging systems. 


\section{Waste Isolation Pilot Plant \\ Groundwater Protection Management Program Plan \\ DOE/WIPP 96-2162, Rev. 3}

Interpretation of groundwater surface elevation measurements and corresponding fluctuations over time is complicated at WIPP by spatial variation in fluid density both vertically in well bores and areally from well to well. To monitor the hydraulic gradients of the hydrologic flow systems at WIPP accurately, actual groundwater surface elevation measurements are monitored at the frequencies specified in Table 3-3, and the densities of the fluids in selected well bores are measured annually. When both of these parameters are known, equivalent freshwater heads can be calculated. The concept of freshwater head is discussed in Lusczynski (1961).

A discussion explaining the calculation of freshwater heads from mid-formation depth at WIPP can be found in Haug, et al. (1987). Freshwater heads are useful in identifying hydraulic gradients in aquifers of variable density such as those existing at the WIPP site. Freshwater head at a given point is defined as the height of a column of freshwater that will balance the existing pressure at that point (Lusczynski, 1961).

Measured groundwater surface elevation data can be converted to equivalent freshwater head from knowledge of the density of the borehole fluid, using the following formula.

$$
p=\rho g h
$$

where

$$
\begin{aligned}
& p=\text { freshwater head (pressure) } \\
& g=\text { freshwater density (mass/volume) } \\
& h=\text { fluid column height above the datum (length) }
\end{aligned}
$$

If the freshwater density is assumed to be 1.000 gram per cubic centimeter, the equivalent freshwater head is equal to the fluid column height times the average borehole fluid density (expressed as specific gravity).

Groundwater surface elevation data are used to determine the direction and rate of flow in the Culebra at least annually. The results of the determination of direction and flow rate are presented annually in the SER.

\subsubsection{Field Methods and Data Collection Requirements}

To obtain an accurate groundwater surface elevation measurement, a calibrated waterlevel measuring device is lowered into a test well and the depth to water recorded from a known reference point.

When using an electrical conductance probe, the depth to water is determined by reading the appropriate measurement markings on the embossed measuring tape when the alarm is activated at the surface. WIPP procedures specify the methods to be used in obtaining groundwater-level measurements. 


\section{Waste Isolation Pilot Plant \\ Groundwater Protection Management Program Plan \\ DOE/WIPP 96-2162, Rev. 3}

\subsubsection{Pressure Density Survey Measurements}

The pressure density program was developed to supplement water level surface elevation calculation of fresh water head values (Crawley, 1988).

The pressure density is derived in such a way that the well is not drawn down and there is as little disturbance to the well bore water as possible.

As previously described, naturally occurring groundwater in the Culebra Member of the Rustler Formation exhibits highly variable TDS concentrations across the WIPP site area. The aerial changes in TDS concentration is reflected in a commensurate variability in formation fluid density. At WIPP, groundwater levels are typically expressed as equivalent-freshwater-heads values. These equivalent-freshwater-heads are calculated using the actual measured water level, adjusted for the specific formation fluid density defined at the particular monitoring well location. These adjusted water levels allow more accurate determination of groundwater-flow directions and gradients. Many of the WIPP water-level-monitoring wells were constructed with open-hole completion intervals or were drilled through the Culebra into the Los Medaños Member of the Rustler Formation. Also, many wells have been pumped, reconditioned, or have been reconfigured at some point in their existence. These various activities have often resulted in the density of well-bore fluids not being representative of or equal to that found in the surrounding water-bearing formation. Therefore, fluid densities defined from past sampling activities may not be representative of what exists in the well-bore today.

The Pressure-Density Survey was developed to accurately measure the density of the fluid standing in groundwater-level monitoring wells now. As discussed above, determining well-bore fluid density is necessary to accurately define groundwater flow directions and gradients. Module V, Section $\mathrm{H}$ of the HWFP requires WIPP to determine and report groundwater flow rate and direction annually. These regulatory requirements and those contained in Attachment L, Section 4 (c) (1) dictate that WIPP measure fluid densities at least once each year.

These surveys are conducted using a trailer mounted cable-reel assembly, containing 1,100 feet of digital insulated cable. A highly accurate pressure-transducer probe is attached to the cable and lowered into the well. Pressure measurements are made at atmospheric and at the mid-formation level combined with water level surface measurements. An average density is then estimated for the water column.

\subsubsection{Groundwater Surface Elevation Records and Document Control}

All incoming data are processed in a timely manner to assure data integrity.

The data management process for groundwater surface elevation measurements begin with completion of the field data sheets. Date, time, tape measurement, equipment identification number, calibration due date, initial of the field personnel, and 


\section{Waste Isolation Pilot Plant \\ Groundwater Protection Management Program Plan \\ DOE/WIPP 96-2162, Rev. 3}

equipment/comments are recorded on the field data sheets. If, for some unexpected reason, a measurement is not possible (i.e., a test is under way that blocks entry to the well bore), a notation as to why the measurement was not taken is recorded in the comment column. Personnel also use the comment column to report any security observations (e.g., well lock missing).

Data recorded on the field data sheets and submitted by field personnel are subject to guidelines outlined in WIPP environmental procedures. These procedures specify the processes for administering and managing such data. The data are entered onto a computerized work sheet. The work sheet contains calculations of groundwater surface elevation in both feet and meters relative to the top of the casing and also relative to mean sea level. The work sheet also contains adjusted groundwater surface elevations to equivalent freshwater heads.

A check print is made of the work sheet printout. The check print is used to verify that data taken in the field was properly reported on the database printout. A minimum of 10 percent of the spreadsheet calculations are verified randomly on the check print to ensure that calculations are being performed correctly. If errors are found, the work sheet is corrected. The data contained on the computerized work sheet are translated into a database file. A printout is made of the database file. The data each month are then compiled into report format and transmitted to the appropriate agencies as requested by the CBFO. Groundwater surface elevation data and equivalent freshwater heads for all Culebra wells are transmitted to the NMED one month after data are collected.

A computerized database file is maintained for all groundwater surface elevation data. Monthly and quarterly data are appended into a yearly file. Upon verification that the yearly database is free of errors, it is appended into the project database file. A printed copy of the current project database (through December of the preceding year) is kept in the Environmental Monitoring and Hydrology fire-resistant storage area (Operating Record).

\subsubsection{Groundwater Surface Elevation Monitoring Equipment Calibration Requirements}

The equipment used in taking groundwater surface elevation measurements is maintained in accordance with WIPP procedures. Environmental Monitoring and Hydrology is responsible for calibrating the needed equipment on schedule in accordance with written procedures. Environmental Monitoring and Hydrology also is responsible for maintaining current calibration records for each piece of equipment.

\subsection{Records Management}

Records generated during groundwater sampling and groundwater surface elevation monitoring events are maintained in the Environmental Monitoring and Hydrology form project files (Operating Record). 


\section{Waste Isolation Pilot Plant \\ Groundwater Protection Management Program Plan \\ DOE/WIPP 96-2162, Rev. 3}

Project records include, but are not limited to:

- $\quad$ Sampling and Analysis Plans

- SOPs

- $\quad$ STLBs

- $\quad$ RFA and CofC forms

- $\quad$ Contract Analytical Laboratory Data Reports

- Variance Logs and Nonconformance Reports

- $\quad$ Corrective Action Reports

These and all raw analytical records generated in conjunction with groundwater sampling and groundwater surface elevation monitoring are stored in fire-resistant cabinets according to the WIPP Records Management Program (WP15-PR) and the Records Inventory and Disposition Schedule (RIDS) and are made available for inspection upon request. The following records are transmitted to Project Records Services for long-term storage in accordance with the RIDS:

- Instrument maintenance and calibration records

- $\quad$ QC sample data

- $\quad$ Control charts and calculation

- Sample tracking and control documentation

- Raw analytical results

\subsection{Quality Assurance Requirements}

Specific QA requirements for WIPP are defined in WP 13-1. Requirements specific to the DMP are presented in this section.

\subsection{QA Program Overview}

The QA program was developed to assure that integrity and quality are maintained for all samples collected and that equipment and records are maintained in accordance with EPA guidance.

The QA program identifies data quality objectives (DQOs), processes for assuring sample quality, and processes for generating and maintaining quality records.

\subsubsection{DQOs}

DQOs are qualitative and quantitative statements that specify the quality of data required to support project decisions.

DQOs are established to ensure that the data collected are of a sufficient and known quality for their intended uses. The overall DQO for this project is to collect accurate and defensible data of known quality that are sufficient to assess the concentrations of constituents in the groundwater underlying the WIPP area. 


\section{Waste Isolation Pilot Plant \\ Groundwater Protection Management Program Plan \\ DOE/WIPP 96-2162, Rev. 3}

The data generated thus far by the DMP have been used to establish background groundwater quality. For the purpose of this DMP, DQOs for measurement data are specified in terms of accuracy, precision, completeness, representativeness, and comparability. Measurements of data quality in terms of accuracy and precision are derived from the analysis of QC samples generated in the field and laboratory.

Appropriate QC procedures are used so that known and acceptable levels of accuracy and precision are maintained for each data set. This section defines the acceptance criteria for each QC analysis performed. The following subsections define each DQO.

\subsubsection{Accuracy}

Accuracy is the closeness of agreement between a measurement and an accepted reference value. When applied to a set of observed values, accuracy is a combination of a random component and a common systematic error (bias) component.

Measurements for accuracy include analysis of calibration standards, laboratory control samples, matrix spike samples, and surrogate spike samples. The bias component of accuracy is expressed as percent recovery $(\% \mathrm{R})$. Percent recovery is expressed as follows:

$$
\% R=\frac{(\text { measured sample concentration })}{\text { true concentration }} \times 100
$$

\subsubsection{Accuracy Objectives for Field Measurements}

Field measurements will include $\mathrm{pH}, \mathrm{SC}$, temperature, Eh, and static groundwater surface elevation. Field measurement accuracy is determined using calibration check standards. Thermometers used for field measurements are calibrated to the National Institute for Standards and Technology (NIST) traceable standard on an annual basis to assure accuracy.

Accuracy of groundwater surface elevation measurements are checked before each measurement period by verifying calibration of the device within the specified schedule. The QAPD, Section 2.4.4, Monitoring, Measuring, Test and Data Collection Equipment, outlines the basic requirements for field equipment use and calibration. WP 10-AD.01, Metrology Program, contains instructions that outline protocols for maintaining current calibration of groundwater surface elevation measurement instrumentation.

\subsubsection{Accuracy Objectives for Laboratory Measurements}

Analytical system accuracy is quantified using the following laboratory accuracy QC checks: calibration standards, laboratory control samples (LCS), laboratory blanks, matrix and surrogate spike samples. Single LCSs and matrix spike and surrogate spike sample analyses are expressed as \%R. Laboratory analytical accuracy is parameter dependent and are prescribed in the laboratory SOP. 


\section{Waste Isolation Pilot Plant \\ Groundwater Protection Management Program Plan \\ DOE/WIPP 96-2162, Rev. 3}

\subsubsection{Precision}

Precision is the agreement among a set of replicate measurements without assumption or knowledge of the true value. Precision data are derived from duplicate field and laboratory measurements. Precision is expressed as relative percent difference (RPD), which is calculated as follows:

$$
R P D=\frac{\mid(\text { measured value sample } 1-\text { measured value sample 2) } \mid}{\text { average of measured samples } 1+2} \times 100
$$

\subsubsection{Precision Objectives for Field Measurements}

Precision of field measurements of water-quality parameters meet or exceed required reporting levels. The $\mathrm{SC}, \mathrm{pH}$, temperature and, optionally, Eh is measured during well purging and after sampling. The SC measurements are precise to \pm 10 percent $\mathrm{pH}$ to 0.10 standard unit, and temperature to $0.10^{\circ} \mathrm{C}$, Eh to 10 millivolts.

\subsubsection{Precision Objectives for Laboratory Measurements}

Precision of laboratory analyses are assessed by performing the same analyses twice on LCSs with each analytical batch assessed at a minimum frequency of 1 in 20 groundwater samples for nonradiological parameters and 1 in 10 for radiological parameters. The laboratory determines analytical precision control limits by performing replicate analyses of control samples. Precision measurements are expressed as RPD. Laboratory analytical precision is also parameter dependent and are prescribed in laboratory SOPs.

\subsubsection{Contamination}

In addition to measurements of precision and bias, QC checks for contamination are performed. QC samples including trip blanks, field blanks, and method blanks are analyzed to assess and document contamination attributable to sample collection equipment, sample handling and shipping, and laboratory reagents and glassware.

Trip blanks are used to assess VOC sample contamination during shipment and handling and are collected and analyzed at a frequency of one sample per sample shipment.

Field blanks are used to assess field sample collection methods and are collected and analyzed at a minimum frequency of one sample per 20 samples (5 percent of the samples collected).

Method blanks are used to assess contamination resulting from the analytical process and are analyzed at a minimum frequency of one sample per 20 samples, or 5 percent of the samples collected. 


\section{Waste Isolation Pilot Plant \\ Groundwater Protection Management Program Plan \\ DOE/WIPP 96-2162, Rev. 3}

Evaluation of sample blanks is performed following U.S. EPA "National Functional Guidelines for Organic Data Review" (EPA, 1991) and "Functional Guidelines for Evaluating Inorganics Analyses" (EPA, 1988). Only method blanks are analyzed via wet chemistry methods. The criteria for evaluating method blanks are established as follows: If method blank results exceed reporting limits, then that value becomes the detection limit for the sample batch. Detection of analytes of interest in blank samples may be used to disqualify some samples, requiring resampling and additional analyses on a case-by-case basis.

\subsubsection{Completeness}

Completeness is a measure of the amount of usable valid data resulting from a data collection activity, given the sample design and analysis. Completeness may be affected by unexpected conditions that may occur during the data collection process. Occurrences that reduce the amount of data collected include sample container breakage in the laboratory and data generated while the laboratory was operating outside prescribed QC limits. Attempts are made to minimize data loss and to recover lost data whenever possible. The completeness objective for noncritical measurements (i.e., field measurements) is 90 percent and 100 percent for critical measurements (i.e., compliance data). If the completeness objective is not met, the Environmental Monitoring and Hydrology manager will determine the need for resampling on a caseby-case basis. Numerical expression of the completeness $(\% \mathrm{C})$ of data is as follows:

$$
\% C=\frac{\text { number of accepted samples }}{\text { total number of samples collected }} \times 100
$$

\subsubsection{Representativeness}

Representativeness is the degree to which sample analyses accurately and precisely represent the media they are intended to represent. Data representativeness for this DMP are accomplished through implementing approved sampling procedures and the use of validated analytical methods. Sampling procedures are designed to minimize factors affecting the integrity of the samples. Groundwater samples are collected only after well purging criteria have been met. The analytical methods selected are those which most accurately and precisely represent the true concentration of analytes of interest.

\subsubsection{Comparability}

Comparability is the extent to which one data set can be compared to another. Comparability is achieved through reporting data in consistent units and collection and analysis of samples using consistent methodology. Aqueous samples consistently are 


\section{Waste Isolation Pilot Plant \\ Groundwater Protection Management Program Plan \\ DOE/WIPP 96-2162, Rev. 3}

reported in units of measures dictated by the analytical method. Units of measure include:

- $\quad$ Milligrams per liter ( $\mathrm{mg} / \mathrm{l})$ for alkalinity, inorganic compounds, and metals - Micrograms per liter (mcg/l) for VOCs.

Groundwater surface elevation measurements are expressed as equivalent freshwater elevation in feet above mean sea level.

\subsection{Plugging and Abandonment of Monitoring Wells}

WIPP has undertaken the responsibility of plugging and abandonment (P\&A) of a large number of older groundwater monitoring wells located in the vicinity of the site. Many of these wells are damaged or no longer provide useful data to the Groundwater Monitoring Program at WIPP.

Exploration drilling and monitor well installation have been in progress at WIPP since 1974, including the new WQSP wells drilled in 1994 to support HWFP detection monitoring. Many of the older wells have become unusable or defective due to highly concentrated subsurface brines that are present in the completion zones. Other wells have been damaged by surface vehicle accidents or other causes. Damaged wells as well as older well pads that have multiple well installations no longer yield essential data, provide redundant data, or yield no data at all. The existence of unneeded wells presents both a safety hazard and poses potential environmental dangers.

The main purposes of the P\&A program is to reduce CBFO liability and potential environmental damage by preventing disturbances to the existing hydrologic conditions in the subsurface domain in the vicinity of WIPP. The objectives of the P\&A program include:

$\begin{array}{ll}\text { - } & \text { Eliminate physical hazards } \\ \text { - } & \text { Prevent groundwater contamination } \\ \text { - } & \text { Conserve aquifer yield and hydrostatic head } \\ \text { Comply with state and federal regulations }\end{array}$

The New Mexico State Engineer Office has regulatory authority over the P\&A of groundwater production and monitoring wells in the state. The state of New Mexico has several groundwater basins, with each basin having its own district office providing oversight of groundwater issues. The WIPP area is under the jurisdiction of the Roswell, New Mexico, branch of the State Engineer Office. The Roswell office is the regulatory body to approve the WIPP plans for well P\&A.

This section presents the WIPP Groundwater Monitoring Well P\&A strategy. The information incorporated within this section includes well history data, justification for 


\section{Waste Isolation Pilot Plant \\ Groundwater Protection Management Program Plan \\ DOE/WIPP 96-2162, Rev. 3}

abandonment, well selection criteria, safety practices, regulatory requirements, and specifications for the field program.

\subsubsection{Historical Profile of WIPP Wells and Justification for Abandonment}

At the present time, the WIPP area wide groundwater-monitoring network contains over 70 accessible wells, the majority of which are completed in the Culebra. Most of these wells are in reasonably good operating condition. However, some wells have been selected for removal from the monitoring program based on usefulness and condition. Wells were selected for P\&A based on health and safety factors, condition of the well (i.e., casing, annular seal, and production interval), geographic location, and the ability of the well to yield useful data.

\subsubsection{Justification for Selection of Wells Scheduled for Plugging}

Group I wells are those wells that presently (a) pose a threat to health and safety, (b) have been physically damaged, (c) have perceived deficiencies incurred during drilling or recompletion, or (d) do not yield useful data. Group II wells are those wells that still do yield useful data but are redundant to nearby wells that yield similar data. Group III wells are wells that actively yield useful data to the detection monitoring program that, given present monitoring requirements, are maintained for the life of the facility. However, these wells may become candidates for P\&A in the future should conditions change. Wells selected for P\&A are plugged in accordance with New Mexico Oil Conservation Division (OCD), State Engineer Office, or Bureau of Land Management (BLM) regulations and standards as applicable. The following presents a brief historical background and selection justification for Group I and II wells. Group III wells, those that under current conditions, are maintained as part of the monitoring network for the foreseeable future, are identified but not discussed in detail in this program plan.

\subsubsection{Historical Profiles of Wells Scheduled for Abandonment}

The bulk of the exploration and monitoring wells were drilled between 1974 and 1980 using standard oil field drilling technology. Standard oil field steel well casing, either $\mathrm{K}-55$ or J-55, was used in well construction. Many of the older surveillance wells were completed using two primary methods.

The first installation method required drilling the well to some depth below the zone of interest and then casing the well to the bottom of the hole. The zone of interest was then perforated using either shot or knife perforation methods.

The second installation method required drilling and casing the well to some point above the zone of interest then reentering the well bore and core drilling through the zone of interest and leaving the formation open to the well bore. 


\section{Waste Isolation Pilot Plant \\ Groundwater Protection Management Program Plan \\ DOE/WIPP 96-2162, Rev. 3}

These types of completions presented numerous problems in collecting useful water quality data. The open-hole completions resulted in halite rich sediments of lower formations being exposed to the sampling zone in some cases. In addition, many of the open-hole completion wells now have blocked or caved in sections at the base of the well due to the exposed formation fracturing, breaking off and falling into the well bore. In most cases, the open sampling zone has collapsed from the stress of multiple pumping events filling in the interval with debris to the bottom of the cased portion of the well. In addition, several of the early wells were drilled for subsurface geologic exploration and stratigraphic correlation purposes. Holes such as WIPP-12 and DOE-1 were drilled to depths of several thousand feet to formations below the repository horizon. These deeper wells have been plugged back or had various types of packer arrangements inserted to shut in and isolate the deeper section of the borehole from shallower zones that were being monitored. In most cases the deeper sections of these wells have not been cased and are presently open-hole completions.

The casings in most of the older wells may have extensive corrosion due to exposure to the brackish-to-brine water found in the WIPP area. The casing in many wells may become degraded and even corroded away due to the presence of high TDS waters, making these wells useless for sampling or monitoring.

\subsubsection{Field Program}

The field program carried out for P\&A of monitor wells is carefully planned and structured to meet the goals and high quality standards of the WIPP Project.

This section discusses preliminary evaluation techniques, abandonment techniques, regulatory requirements, materials and specifications, requirements for testing plugs and seals after emplacement, and the safety practices of the field program.

\subsubsection{Preliminary Evaluation}

Each well considered as a candidate for P\&A is thoroughly evaluated prior to plugging. An on-site inspection is performed to determine obvious damage to the surface components. A complete records examination of well construction and re-completions is performed to evaluate any potential for future usefulness to the project. Drawings, field notes and published reports pertaining to the completion of the well and historical monitoring results are reviewed during the evaluation. Having completed all necessary visual and records searches, physical examinations are performed to determine the current condition of the well bore. Physical examination of the well bore is conducted to determine the current condition of the well bore. There are several methods available to evaluate the condition of the casing and cement bond. Evaluation methods will include ultrasonic imaging (USI), cement bond logs, borehole television logs, and three armed caliper logs.

USI with high resolution provides the ability to inspect the condition of both the casing and the cement bond. At present, USI technology is the preferred method of borehole 


\section{Waste Isolation Pilot Plant \\ Groundwater Protection Management Program Plan \\ DOE/WIPP 96-2162, Rev. 3}

inspection. However, other methods of evaluation are discussed below to provide alternative techniques in the event that USI becomes unavailable. The P\&A program will not be limited to the methods discussed in this plan and may consider other methods and new technologies, as they become available.

\subsubsection{Field Well Logging Techniques}

Useful well logging and imaging techniques available for evaluating WIPP area wells are described below.

\subsubsection{Ultrasonic Imaging}

Ultrasonic imaging is accomplished by filling the well bore with uniform density fluid. An ultrasonic probe is lowered slowly down the well bore. As the probe is lowered it spins very rapidly at the same time emitting sonic waves that bounce off the side of the casing and return to the probe. By measuring the length of time and intensity of the sonic wave when it returns to the probe, casing and cement bond can be imaged by digitizing the response times and running the data through sophisticated computer programs. Problem areas such as a break or crack in the casing or plugged perforations can be enlarged and examined for greater clarity. The main advantage to using USI is that comprehensive integrity logging for both casing and cement can be performed producing visual result using the same tool. The primary disadvantage of the technique is the potential for introducing foreign fluids into the well bore.

\subsubsection{Cement Bond Logs}

Cement bond logs are accomplished by lowering a radioactive source into the borehole and measuring the deflected radiation. This type of evaluation is only effective for evaluating the integrity of the cement bond and must be used in conjunction with other evaluation techniques to determine casing integrity. Another disadvantage of the cement bond log is the potential of losing a radioactive source in the well.

\subsubsection{Borehole Television Log}

The borehole television log is accomplished by lowering a submersible camera slowly down the well bore. The borehole television log provides a means to visually inspect the condition of the casing wall. The log can be video taped for record archive or further study. The borehole television log cannot be used to evaluate the condition of the cement bond and must be used in conjunction with other evaluation techniques to perform a full evaluation. Borehole television logs may be ineffective in wells with high turbidity. 


\section{Waste Isolation Pilot Plant \\ Groundwater Protection Management Program Plan \\ DOE/WIPP 96-2162, Rev. 3}

\subsubsection{Three-Armed Caliper Log}

Three-armed caliper logs are accomplished by lowering the caliper to the bottom of the borehole, expanding the caliper arms and slowly raising the caliper to the surface. A three-arm caliper log will not reveal the exact nature of a casing irregularity such as collapsed casing versus a build up of rust or scale on the inside of the casing. The three-armed caliper must be run in conjunction with other evaluation techniques to determine the exact nature of the casing irregularities and the integrity of the cement bond.

\subsubsection{Regulatory Requirements}

The P\&A of WIPP monitoring wells is performed following applicable state and federal regulations. In general, the drilling, operation, and abandonment of groundwater wells, are regulated by the State Engineer Office. The appropriate district branch or Artesian Conservancy District will have the authority and responsibility of approving all abandonment plans and methodologies. The regulations also direct that a State Engineer Office representative will observe and supervise field abandonment activities.

Section 19.27.1.16 NMAC, Recommended Rules and Regulations for the Administration of Water, provides the necessary specifications for the P\&A of wells at WIPP. These regulations are clear and specific about the requirements for plugging abandoned water wells which penetrate artesian or confined groundwater strata. Most wells at WIPP completed in the Rustler Formation or deeper geologic horizons have penetrated or are completed in artesian water-bearing formations. These requirements include:

- The determination if a geologic unit is artesian rests with the State Engineer Office.

- A permit from the office is required prior to drilling or abandoning a water well.

- The permit shall specify requirements for drilling or plugging wells including witnessing the field effort.

- $\quad$ Every borehole and abandoned well shall be plugged in accordance with this article. All wells where the casing has failed or the well is not properly cased shall be deemed abandoned and shall be plugged within one year from the date of these regulations.

- If a well was previously cased and the casing cannot be removed, the well shall be plugged by cutting the casing off below ground surface at least three feet and either filling the well casing to the ground surface with heavy cement slurry weighing no less than 15 pounds per gallon, or filling the well with heavy bentonite based drilling mud or with dry, granular bentonite based material, the weight of which is great enough to prevent flow of water into the hole from any penetrated aquifer unit. 


\section{Waste Isolation Pilot Plant \\ Groundwater Protection Management Program Plan \\ DOE/WIPP 96-2162, Rev. 3}

- A 10-foot interval of 15-pounds-per-gallon cement slurry plug shall be placed above the bentonite material to ground surface both inside and outside the casing by forcing the cement down the casing or using a tremmie tube.

•

Casings with no screen or perforations shall be perforated to allow the flow of plugging material into the entire annulus between the casing and the hole. Sealing material shall be placed from the bottom of the well upward to avoid segregation or dilution of the plugging material.

- Specific plugging requirements may be set forth as conditions of approval of a permit obtained from the State Engineer Office.

In general, the method typically used in the Carlsbad Underground Water Basin is to remove all of the casing from the hole, clean the hole to the bottom using sand pump or cable tool drilling rig with a bailer, and to fill the hole with red clay or circulate the hole full of cement slurry.

Many of the wells scheduled for P\&A are located on land administered by the BLM. The BLM does not have specific guidelines or regulations for P\&A of groundwater wells and relies on the State Engineer Office to prescribe and enforce well abandonment procedures. The BLM does require the party that is responsible for well plugging to notify their office in order to be granted permission for surface access and to perform work on BLM lands.

However, though not directly applicable to WIPP monitoring wells, the BLM does have requirements for the plugging of oil and gas wells and mineral (potash) exploration boreholes. These requirements are derived from New Mexico OCD Regulation R-111-P and regulations given in 43 CFR Part 3160, Subpart 3162.3-4; and 43 CFR Part 3590, Subpart 3593.1. In general, these regulations specify relatively strict plugging methodologies for wells and boreholes located within the oil-potash area. WIPP has adopted the guiding philosophy of abandoning wells in a manner that meets or exceeds the most stringent regulations. Therefore, OCD and BLM regulations that apply to oil and gas wells and potash boreholes are relative to plugging and abandoning groundwater-monitor wells at WIPP.

The OCD Regulation R-111-P, which generally applies to the plugging of oil and gas wells, requires that solid cement plugs be installed through the Salado salt section and any water bearing horizons to prevent liquids or gases from entering the hole from above or below the salt section. These regulations also state that the cement to be used to plug through the salt section (the Salado and Castile Formations) is mixed with salt saturated fluids made from salts from the specific horizon being plugged. This regulation would thus require that all wells scheduled for $P \& A$ and that were drilled into or through the Salado Formation be plugged with cement made up from salt from the repository horizon. The WIPP CCA commits to following OCD Regulation R-111-P for plugging several of the deeper wells, specifically WIPP-13, WIPP-12, ERDA-9, and 


\section{Waste Isolation Pilot Plant \\ Groundwater Protection Management Program Plan \\ DOE/WIPP 96-2162, Rev. 3}

DOE-1. These requirements are not more stringent than those required by the State Engineer Office requirements for water well abandonment.

Potash coreholes, and those which have been converted to monitor wells such as P-14 and P-18 in the area of WIPP, are considered to be within and are part of the Carlsbad Underground Water Basin. These potash test holes fall under the jurisdiction of the State Engineer. The proposed draft State Engineer regulations require these holes to be plugged from the bottom to top with cement grout weighing no less than 15 pounds per gallon, heavy bentonite based drilling mud, and or dry granular bentonite based material to prevent water flow into the hole or well from any intercepted aquifer unit. Since 1975, 155 potash coreholes have been plugged in the New Mexico portion of the Delaware Basin. Of these, 151 were plugged with solid cement and four with some mixture of mud and cement.

\subsection{Abandonment Techniques}

Based on the results of preliminary assessments and applicable regulatory requirements, a decision is made regarding the best method to be used for P\&A. Materials and best available technology are use to ensure that the abandonment procedure is effective and protective of human health and safety.

The most effective method to ensure a competent well bore plug is to remove the casing, clean out the borehole, and fill the borehole with cement. However, in all probability, there are mitigating circumstances, which prohibit the removal of casing. In those cases where it is not feasible to remove the casing, all reasonable care is used to ensure competent well bore seals are achieved. Some alternative methods of P\&A, with the casing in place, are discussed below.

Under certain circumstance it may be deemed appropriate to plug and abandon some wells by placing a cast iron bridge plug above the casing perforations of the first water bearing zone. The next step is to place a 25-foot plug of cement over the top of the bridge plug and then fill the borehole with drilling mud to the next perforated interval. The process is repeated until the borehole is completely plugged. Adhering to the goal of providing the best available practices to ensure that the abandonment processes are protective of human health and safety, this technique is considered but is not the preferred method to be followed in the P\&A process.

Assuming that no problems are noted with the integrity of the casing or the cement bond and it is determined that the casing cannot be removed, the surface casing can be cut and removed below the ground surface and the borehole filled with cement. Markers can be placed on the surface to mark the location of the well and the well pad can be reclaimed.

In those instances where the integrity of the cement bond is in question, special consideration must be given to the abandonment technique. To ensure that the abandonment process is protective of human health and safety, special steps must be 


\section{Waste Isolation Pilot Plant \\ Groundwater Protection Management Program Plan \\ DOE/WIPP 96-2162, Rev. 3}

taken to ensure that groundwater will not migrate through the annular seal to the accessible environment. When the integrity of the cement bond is questionable, the casing is pulled, if possible. However, if the casing must be left in place, the following alternative may be applied.

The casing can be cut below ground surface and removed and the wellbore cemented from the bottom of the hole to a point just below the suspected breach in the annular seal. After allowing the cement in the wellbore to cure, the well would be reentered and the casing would be perforated across the interval where the cement bond is bad. Cement could then be squeezed through the perforations and into the annular space reinforcing the cement bond. The well bore would then be cemented to the surface and the location marked as applicable.

In cases where the cement bond on the outside of the well casing is determined to be weak, fractured, or missing, additional fresh cement may be injected through perforations to strengthen such areas. These poor cement bond areas can be identified with the USI technique. Selected areas of the well casing can then be perforated using various techniques and fresh cement "squeezed" into the perforated area to add cement to critical areas. In addition, perforations of well casing previously created for monitoring of selected water-bearing intervals can be squeeze cemented to plug the casing openings prior to filling the remaining well bore with cement or other well plugging materials. Areas having fresh cement squeezed into perforations must be allowed to cure for at least 24 hours prior to finishing filling the well bore with cement.

The USI survey of any particular well may reveal that the cement seal between the well casing and well bore wall has numerous deficiencies requiring multiple perforations and squeeze cementing efforts. This type of cement bond rehabilitation may prove to be cost prohibitive. In such cases, the field team leader may elect to have the old casing overdrilled and pulled from the borehole. Overdrilling can be successfully accomplished to approximately 900 feet deep and only for smaller casing diameter such as four-inch casing.

Many wells have retrievable cast iron bridge plugs installed. Most of these plugs are old and have been installed in the wells for many years. Removal of these bridge plugs may prove to be impossible requiring the plug to be drilled or milled out using a drill rig and drill bit.

\subsection{Plugging Materials}

The exact materials used in the P\&A process is guided by regulation and specified by the New Mexico Sate Engineers office. However, it is anticipated that at a minimum Class "C" cement will be used under normal circumstances.

As an option, and where appropriate, boreholes can be plugged from bottom to surface with cement in increments of 200-foot intervals, or an interval specified by the state engineer. Each individual segment of the plug may be allowed to cure for a period that 


\section{Waste Isolation Pilot Plant \\ Groundwater Protection Management Program Plan \\ DOE/WIPP 96-2162, Rev. 3}

will ensure the integrity of the plug before the next plug is installed. If segmented plugging is used, appropriate bonding agents are used between plugs to ensure continuity in the cement column. Discussions with experienced well drilling firms indicated that segmented plugging generally does not result in improved plug integrity or strength and is considerably more expensive.

In accordance with New Mexico OCD requirements, all cement grout to be used to plug the Salado section of open boreholes and the various water bearing zones open to the well is mixed with salt saturated fluids made with salts from the repository horizon.

Considerable research has been conducted at WIPP on materials to be used to seal shafts and boreholes. These studies, in concert with historical experience from routine plugging of oil and gas wells and other boreholes, has shown that concrete is an excellent plugging material. Concrete has exceptionally low permeability and is widely used for hydraulic applications such as water storage tanks, water and sewer systems, and massive dams. Salt saturated concrete such as that proposed for plugging WIPP shafts and wells, has been used successfully as a seal material in potash and salt mining applications. Upon hydration, unfractured concrete is nearly impermeable, having permeabilities less than $10^{-20}$ meters squared. Use of salt saturated concrete is backed by extensive laboratory and field studies that have established performance characteristics that far exceed any regulatory or technical specifications required to adequately plug WIPP monitor wells.

\subsection{Requirements for Field Testing of Plug Integrity}

Regulations for the OCD and State Engineer Office do not specify any type of testing or inspection requirements for the final well plug. In reality, only a small surface exposure or section could reasonably be inspected or tested. No testing techniques exist for determining the competency or integrity of concrete plugs deep below the surface. However, there are some testing techniques available to evaluate the final concrete mix of the surface portion of the plug.

American Society for Testing and Materials specifications contain several concrete testing techniques. Discussions with oil field service and drilling firms have clearly shown that such testing methods are not employed in well plugging programs in both the oil production and water well industries.

\subsection{Field Safety Practices}

Safety is an integral part of the WIPP environment. One of the foremost goals of WIPP is to maintain a safe work place for all employees including that of contractors.

Therefore, WIPP subcontractors are held to the same high standards of safety as those who work directly for the DOE or the MOC.

All field team members must comply with applicable federal laws and regulations as well as additional measures necessary to ensure a safe work place. Applicable provisions of 


\section{Waste Isolation Pilot Plant \\ Groundwater Protection Management Program Plan \\ DOE/WIPP 96-2162, Rev. 3}

the Occupational Safety and Health Administration (29 CFR, Labor; OSHA Publication 2201, General Industry Digest; National Fire Prevention Association, and DOE Orders); EPA regulations; American Petroleum Institute RP 54, Recommended Practices for Occupational Safety for Oil and Gas Well Drilling and Servicing Operations; and state of New Mexico regulations may be applied to any work. Some of the measures taken to ensure that work resulting from this plan is completed in a safe manner are discussed below.

\subsubsection{Safety Meetings}

Safety meetings are an important part of any safety program. They are essential for the conveyance of information flowing to and from management and project technical staff. Information gained from safety meetings are used in making informed decisions critical to the well being and safety of field team members. Two types of safety meetings, the prework/orientation conference and tailgate safety meetings, are discussed below.

\subsubsection{Prework/Orientation Conference}

Field team members may be asked to attend a prework/orientation conference. The prework/orientation conference is used to discuss the upcoming project and some of the hazards involved. Elements of the safety program and personnel training programs are discussed. Subcontractors must have programs such as an accident prevention program which contains the company safety policy statement. This preliminary safety conference also provides a forum for any subcontractors involved to present the job hazard analysis which the field team is trained to. The prework/orientation conference sets the stage for the level of safety expected for the project.

\subsubsection{Tailgate Safety Meetings}

Tailgate safety meetings are informal safety meetings held at the beginning of each workday. Tailgate safety meetings provides the opportunity for the field team to express safety concerns and discuss issues that are unique to the project in an informal setting. The Tailgate safety meeting is an important part of accident prevention. These short, informal meetings keep the lines of communication open between the management and the field team and it keeps safety fresh in the minds of the whole team.

\subsubsection{Programs and Documentation}

Written programs and the documentation implementing those programs are important to any safety program. Some of the programs required for field programs are discussed below. Additional programs may be specified by the statement of work. 


\section{Waste Isolation Pilot Plant \\ Groundwater Protection Management Program Plan \\ DOE/WIPP 96-2162, Rev. 3}

\subsubsection{Accident Prevention Program}

Subcontractors may be asked to present an accident prevention program. The accident prevention program outlines the accident history of the company, contains a safety policy statement and employee safety and training documentation.

The accident history of the company usually is presented in the form of an OSHA 200 document or an equivalent document outlining the accident history of the company over the past 12 months.

\subsubsection{Company Safety Policy}

A company safety policy outlines the safety goals and expectations of the company. The policy statement should also discuss the companies accident prevention strategies and explain how it intends to maintain safe working conditions. Compliance with laws and regulations pertaining to the safety and health of employees, workmanship and quality should also be discussed.

\subsubsection{Safety and Training Documentation}

Field team members should be trained in such things as hazard recognition, emergency procedures, electrical hazards, hazard communication, and hydrogen sulfide safety awareness. A good job hazard analysis is a valuable training aide in field situations. Documentation attesting to the successful completion of training should be completed for each of the field team members.

\subsubsection{Personal Protective Equipment}

Personal protective equipment (PPE) is vital to team members safety. PPE worn by field team members will follow the guidelines set forth in the WIPP safety manual (WP 12-1). The minimum PPE worn by field team members while work is being performed is hard hat, steel toed boots, protective coveralls, and safety glasses. Additional safety equipment such as respirators, gloves and gas monitors may be required as needed depending on the specific well being plugged.

\subsubsection{Housekeeping}

House keeping is important to protect the environment and the safety of the field team. House keeping includes removal of debris from the work site, spill prevention and clean up, and care and maintenance of equipment. The level of housekeeping is a direct reflection of the safety attitude of the project personnel.

All waste generated during field activities is collected, segregated, and managed according to waste composition. Basic household or solid waste such as cans, bottles, plastic wrap, and paper are separated from potentially hazardous chemical, solvent, or solid waste materials. Cement, clay, drilling mud, and sealing compound 


\section{Waste Isolation Pilot Plant \\ Groundwater Protection Management Program Plan \\ DOE/WIPP 96-2162, Rev. 3}

containers/sacks and paint and solvent cans are segregated from other wastes and managed as potentially hazardous waste. The field well plugging contractor will develop and implement a spill control/prevention plan, which will reduce the potential for uncontrolled waste generation. All fuels, plugging materials, salt water/brine, and other potentially hazardous materials are containerized at all times and will not be allowed to spill or contaminate the soil in the well pad area. All fuels and lubricants, such as propane, diesel, gasoline, motor oil, and pipe lubricants are stored and handled as flammable and hazardous materials.

\subsection{Selected Well Plugging Methodology}

Review of applicable state and federal regulations and discussions with area drilling and well plugging contractors has clearly defined the most effective well plugging methodology to be applied to the WIPP wells. The WIPP philosophy of plugging abandoned wells to specifications that meet or exceed the most stringent regulatory requirements is now considered to be straight forward. The accepted "best plugging methodology" involves completely filling the well bore or well casing with Class $\mathrm{C}$ or Class $\mathrm{H}$ cement mixed with salts from the Salado Formation.

However, the proposed procedure for plugging wells at WIPP does offer some activities which are designed to ensure that the final well seal is competent and complete throughout all sections of the well and within all intervals previously open to or perforated within water bearing units. The following description summarizes the stepwise procedure and technical requirements for the WIPP well P\&A program.

\subsubsection{Well Evaluations}

The initial well P\&A activity is to perform preliminary well evaluations and Ultrasonic Imaging of the selected well casing and cement bond. The data obtained from these evaluations are used to determine if the well casing can be pulled and if the casing and cement bond are eroded or broken. If the cement bond is shown to be significantly deteriorated in numerous locations, every attempt is made to pull the well casing, including overdrilling, if feasible. Wells with continuous intact cement bond will generally not have the casing removed.

\subsubsection{Removal of Obstructions}

Many wells presently have bridge plugs and packer assemblies installed down hole. Prior to any well plugging activities, all obstructions are removed from the well. Packers are deflated and pulled from the well and cast iron and other bridge plugs are removed as designed if possible. If bridge plugs are not retrievable, they are drilled out or milled away. Loose material, drilled plugs, deteriorated pieces of casing, and excessive scale are removed to the extent possible prior to commencement of well plugging with cement. 


\section{Waste Isolation Pilot Plant \\ Groundwater Protection Management Program Plan \\ DOE/WIPP 96-2162, Rev. 3}

\subsubsection{Casing Perforations and Squeeze Cementing of Intervals}

Wells which have clearly definable intervals within the annulus (where the USI survey has shown the cement bond to be deteriorated) are perforated across the specific section and cement grout is squeezed into the perforations to rebuild and repair the bond. Portions of the well casings that have well screen or have been perforated to allow communication with water bearing zones will also be squeeze cemented to isolate the well from the water-bearing zone. All squeeze cementing is performed in sequence as the well is cemented in from the bottom of the well upward. All squeeze cemented zones are allowed to cure for at least 24 hours before the remainder of the well is cemented in.

\subsubsection{Final Cementing and Plugging of Wells}

All wells scheduled for P\&A at WIPP will be filled with salt saturated Class $\mathrm{C}$ or $\mathrm{Class} \mathrm{H}$ cement from the bottom to the grounds surface. If the casing was pulled from the well, the remaining borehole is thoroughly cleaned of cement, scale, or other material attached to the borehole wall. The lower section of these types of wells is cleaned of debris and sediment using a down-hole sand pump or other type of pump or bailer. Wells that did not have the casing removed, will have the casings internal surface scraped and cleaned of excess scale and corrosion products. The lower sections of the cased wells will be cleaned using pumping or bailing equipment such as that used in the wells with their casing removed.

In all cases, the casing in each well is cut off at least four feet below the ground surface and removed from the hole prior to plugging with cement. Cement is installed in all wells using a tremmie pipe/tube or drill stem, from the well base upward in smooth uninterrupted columns or sections. As described in the previous section, consistent cement pours may be interrupted in order to install squeeze cement into perforated sections.

Class $\mathrm{C}$ cement is used for plugging most of the shallower wells, and wells that have not penetrated the deeper formations including the Castile and Bell Canyon Formations. The decision concerning the appropriate type of cement is based on well location, drilling/completion intervals, and data relative to known groundwater chemistry and gas occurrences.

\subsubsection{Well Pad Surface Configuration}

The BLM generally requires that oil and gas wells plugged on BLM administered lands have a specific type of surface monument. This monument is used to denote the location and name of the plugged well and other pertinent information. State of New Mexico OCD Rule 202 also requires that the monument for plugged oil and gas wells and potash core holes have their exact locations marked by the operator with a steel marker not less than four inches in diameter, set in concrete, and extending four feet above mean ground level. The metal marker shall be permanently engraved, 


\section{Waste Isolation Pilot Plant \\ Groundwater Protection Management Program Plan \\ DOE/WIPP 96-2162, Rev. 3}

welded, or stamped with the required information. Oil and gas well marker requirements do not directly apply to groundwater monitoring wells. However, many of the wells planned for P\&A reside on BLM controlled land.

WIPP proposes to install a four-inch thick concrete pad extending two by two feet around the previous wellbore location. A brass or steel marker plate is imbedded in the concrete pad over the old wellbore. The metal marker plate will have all of the required well information engraved or stamped as appropriate. The State Engineer Office does not specify surface marker requirements for plugged water wells. Final configuration of abandoned well surface pad and marker features is developed in concert with both BLM and State Engineer Office representatives.

\subsection{Post-Closure Monitoring}

The EPA states, "Post-closure care must be provided for a period of at least 30 years after completion of the authorized closure of the repository. If groundwater monitoring systems are used during the repository active life, they must also be operated and maintained throughout the post-closure care period" (EPA 1986).

Monitoring of the Culebra will continue through the post-closure period as described for the DMP. Changes to the monitoring programs are accomplished through modifications to the HWFP (RCRA Permit) and amendments to the CCA.

Table 3-3

WIPP Groundwater Detection Monitoring Program Sample Collection and Groundwater Surface Elevation Measurement Frequency

\begin{tabular}{||l|l||}
\hline \multicolumn{1}{||c||}{ Installation } & \multicolumn{1}{||}{ Frequency } \\
\hline \multicolumn{1}{||c||}{ Groundwater Quality Sampling } \\
\hline DMP monitoring wells & Semiannually \\
\hline All other WIPP surveillance wells & On special request only \\
\hline \multicolumn{2}{|c||}{ Groundwater Surface Elevation Monitoring } \\
\hline DMP monitoring wells & Monthly and prior to sampling events \\
\hline All other WIPP surveillance well sites & Monthly \\
\hline $\begin{array}{l}\text { Redundant wells at all other WIPP surveillance } \\
\text { well sites }\end{array}$ & Quarterly \\
\hline \hline
\end{tabular}




\section{Table 3-4}

Analytical Parameter List for the WIPP DMP

Background Groundwater Quality
Indicator Parameters
$\mathrm{pH}, \mathrm{SC}, \mathrm{TOC}, \mathrm{TOH}, \mathrm{TDS}, \mathrm{TSS}$, Density
$\frac{\text { Parameters Listed in }}{20.4 .1 .500 \mathrm{NMAC}(\text { Incorporating } 40 \text { CFR Part 264) }}$
Appendix IX, + Calcium, Magnesium, Potassium
Field Analysis
pH, SC, temperature, chloride, Eh, alkalinity, total Fe,
Specific gravity

Background Groundwater Quality

Indicator Parameters

Parameters Listed in

20.4.1.500 NMAC (Incorporating 40 CFR Part 264)

$\mathrm{pH}$, SC, temperature, chloride, Eh, alkalinity, total Fe, Specific gravity
Operational Parameters

Chemical Analysis

Alkalinity Bromide

Sulfate Chloride

Total Organic Carbon (TOC)

Total Organic Halogens (TOX)

Physical Analysis

$\mathrm{pH} \quad$ Density

Total Dissolved solids (TDS)

Total suspended solids (TSS)

Inorganic Metals

Antimony Arsenic Barium

Beryllium Cadmium Chromium

Silver Lead Potassium

Vanadium Nickel Selenium

Calcium Thallium Sodium

Iron Magnesium

Volatile Organic Compounds (VOCs)

1,1-dichloroethylene Carbon Tetrachloride

Methylene Chloride Chloroform

1,1,2,2-tetrachloroethane 1,1,1-trichloroethane

Chlorobenzene

Toluene

Vinyl Chloride

1,2-dichloroethane

1,1-dichloroethane

Methyl Ethyl Ketone Tetrachloroethylene

cis-1,2-dichloroethylene Trichloroethylene

Trichlorofluoromethane 1,1,2-trichloroethane

Trans-1,2 Dichloroethylene

Semivolatile Organic Compounds (SVOCs)

Cresols (Total) 1,2-dichlorobenzene

2,4-dinitrophenol Hexachloroethane

Pyridine

Nitrobenzene

1,4-dichlorobenzene 2,4-dinitrotoluene

Hexachlorobenzene Pentachlorophenol

Phenols (Total)

Radionuclides of Interest

$\mathrm{K}^{40}, \mathrm{Cs}^{137}, \mathrm{Co}^{60}, \mathrm{U}^{234}, \mathrm{U}^{235}, \mathrm{U}^{238}, \mathrm{Pu}^{238}, \mathrm{Pu}^{239+240}, \mathrm{Am}^{241}$ 


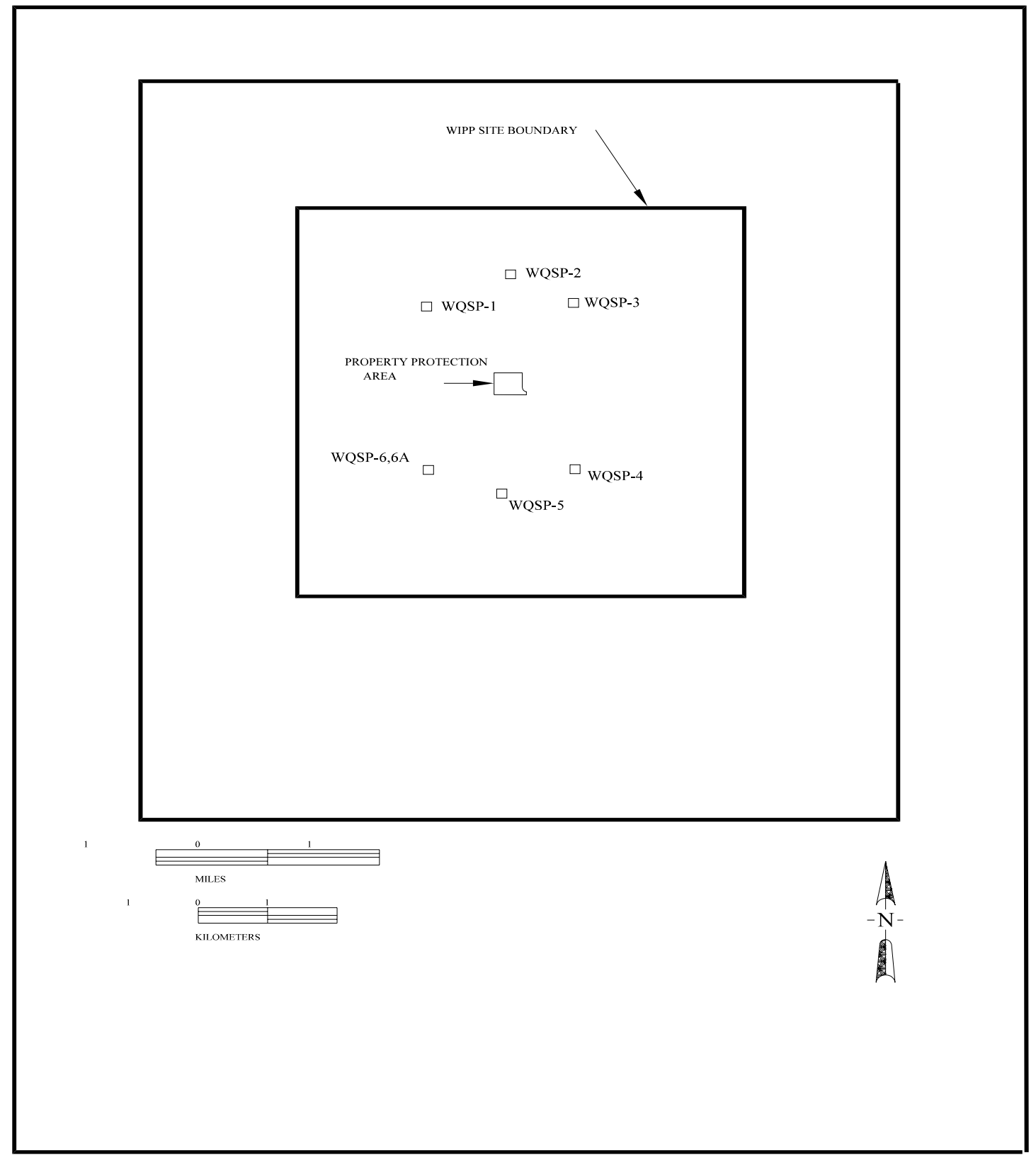

Figure 3-1 - Detection Monitoring Well Locations 
Waste Isolation Pilot Plant

Groundwater Protection Management Program Plan

DOE/WIPP 96-2162, Rev. 3

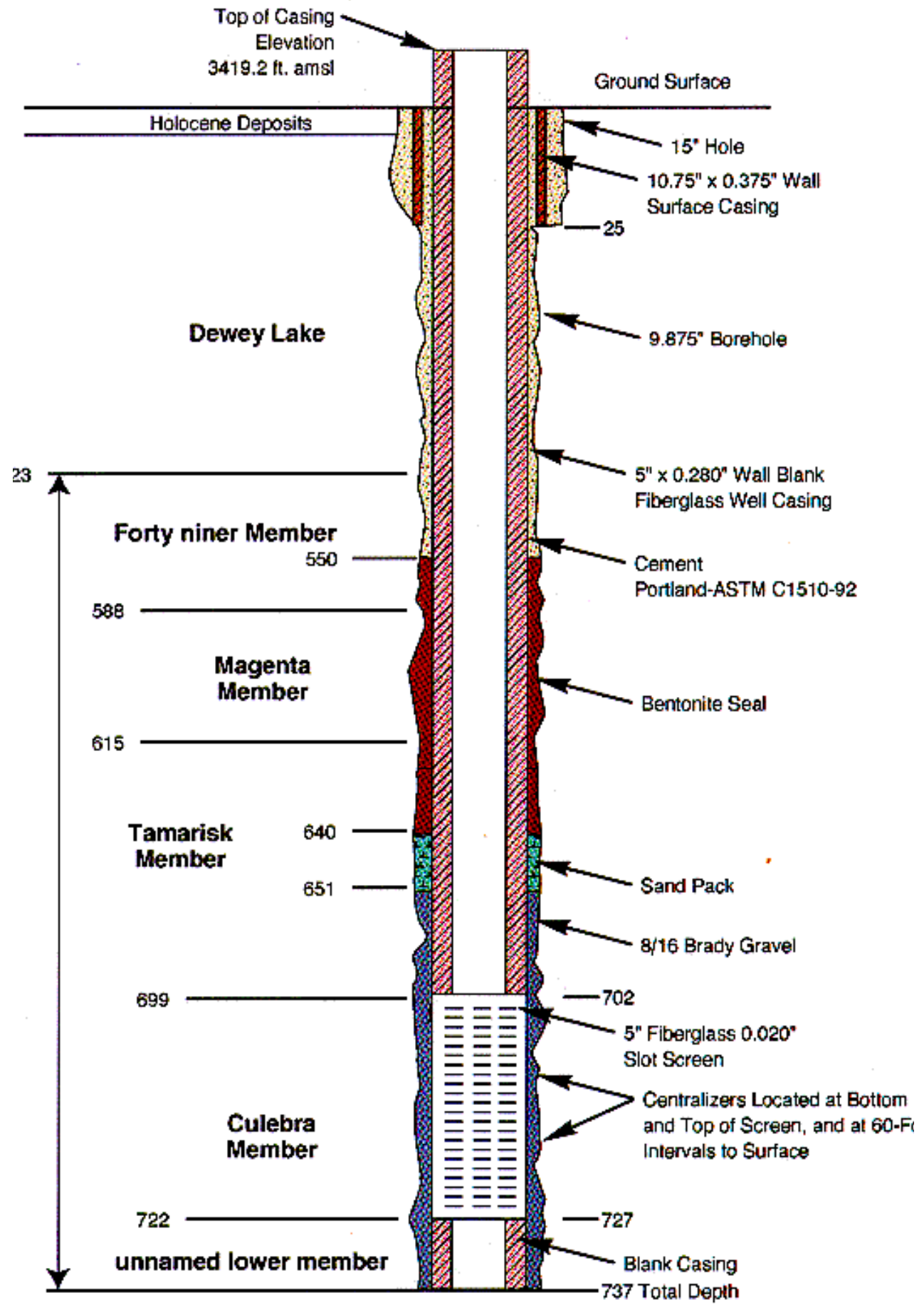

Note: Depths in feet bgs approximate Not to Scale

Figure 3-2 - As-Built Configuration of Well WQSP-1 


\section{Waste Isolation Pilot Plant \\ Groundwater Protection Management Program Plan \\ DOE/WIPP 96-2162, Rev. 3}

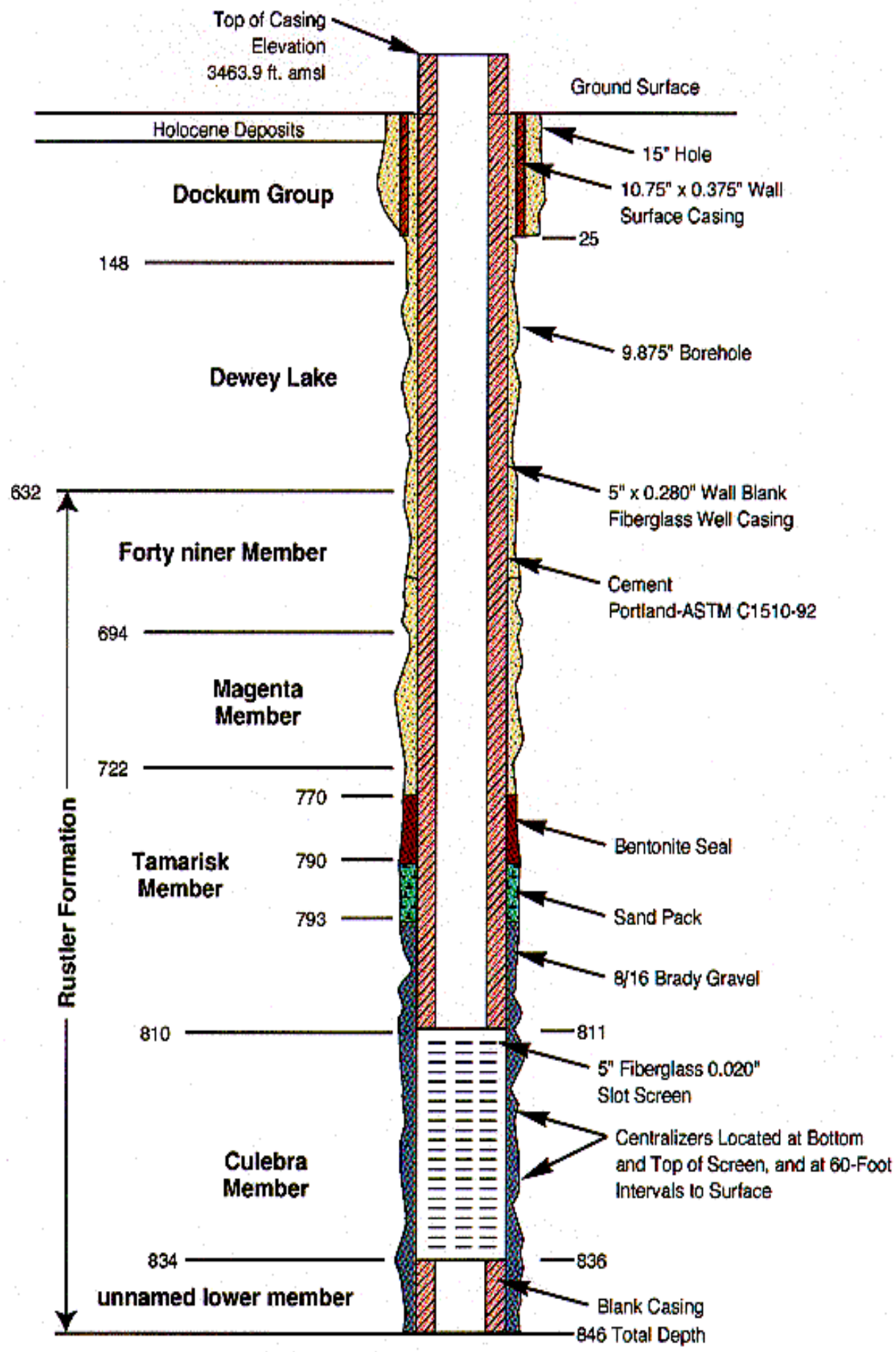

Note: Depths in feet bgs approximate Not to Scale

Figure 3-3 - As-Built Configuration of Well WQSP-2 


\section{Waste Isolation Pilot Plant \\ Groundwater Protection Management Program Plan \\ DOE/WIPP 96-2162, Rev. 3}

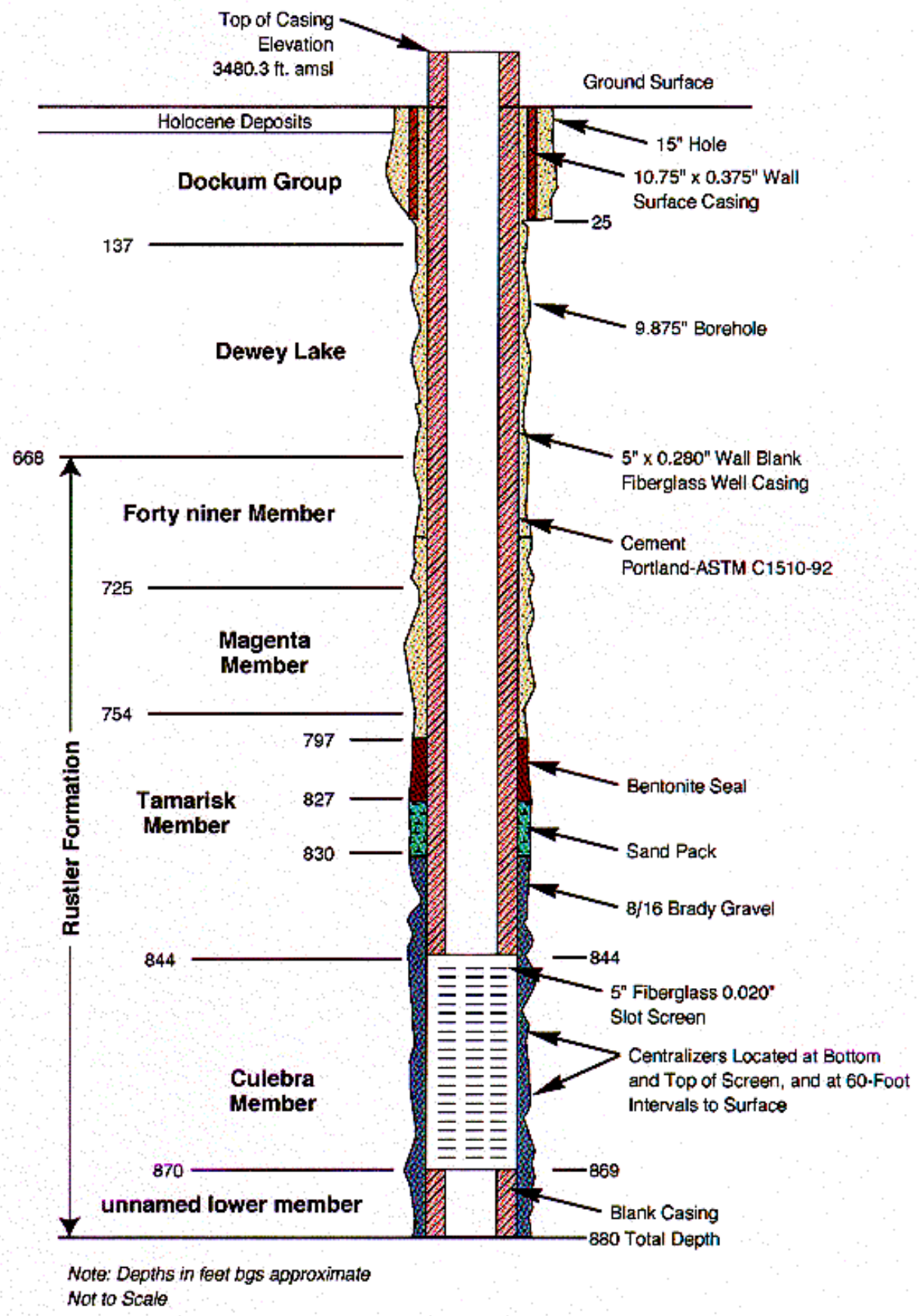

nmonatก

Figure 3-4 - As-Built Configuration of Well WQSP-3 


\section{Waste Isolation Pilot Plant \\ Groundwater Protection Management Program Plan \\ DOE/WIPP 96-2162, Rev. 3}

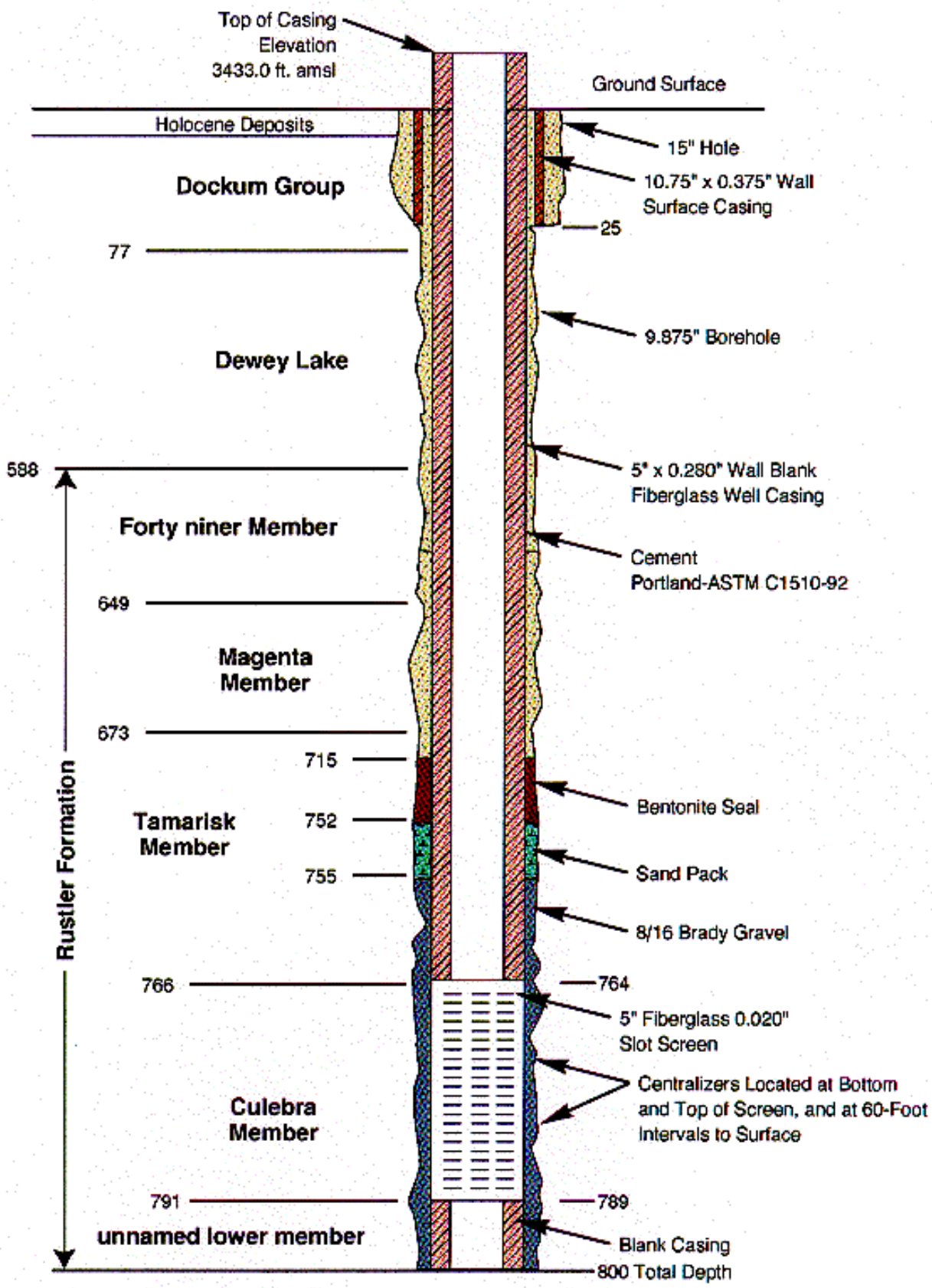

Note: Depths in feet bgs approximate

Not to Scale

Figure 3-5 - As-Built Configuration of Well WQSP-4 


\section{Waste Isolation Pilot Plant \\ Groundwater Protection Management Program Plan \\ DOE/WIPP 96-2162, Rev. 3}

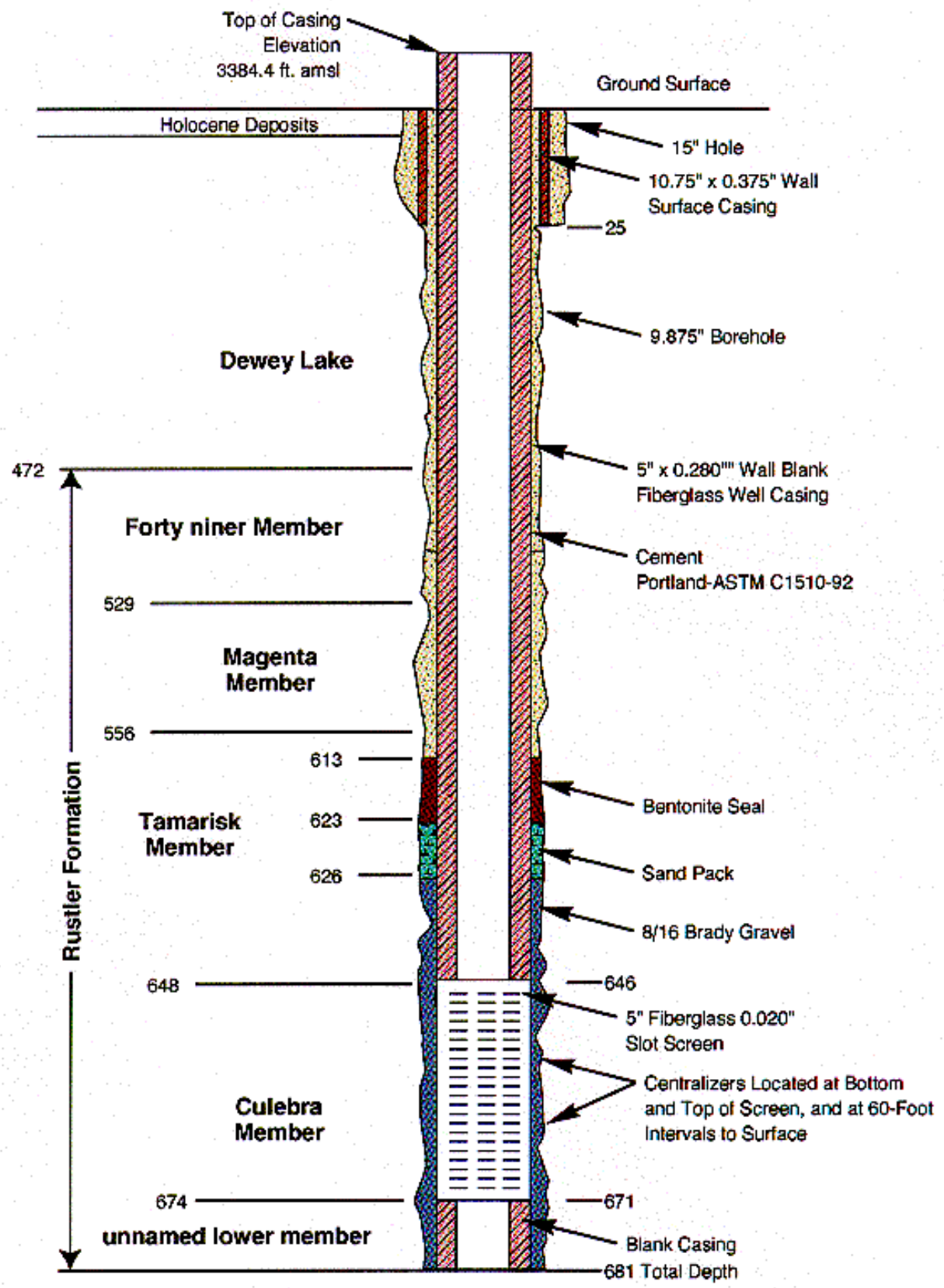

Note: Depths in feet bgs approximate Not to Scale 


\section{Waste Isolation Pilot Plant \\ Groundwater Protection Management Program Plan \\ DOE/WIPP 96-2162, Rev. 3}

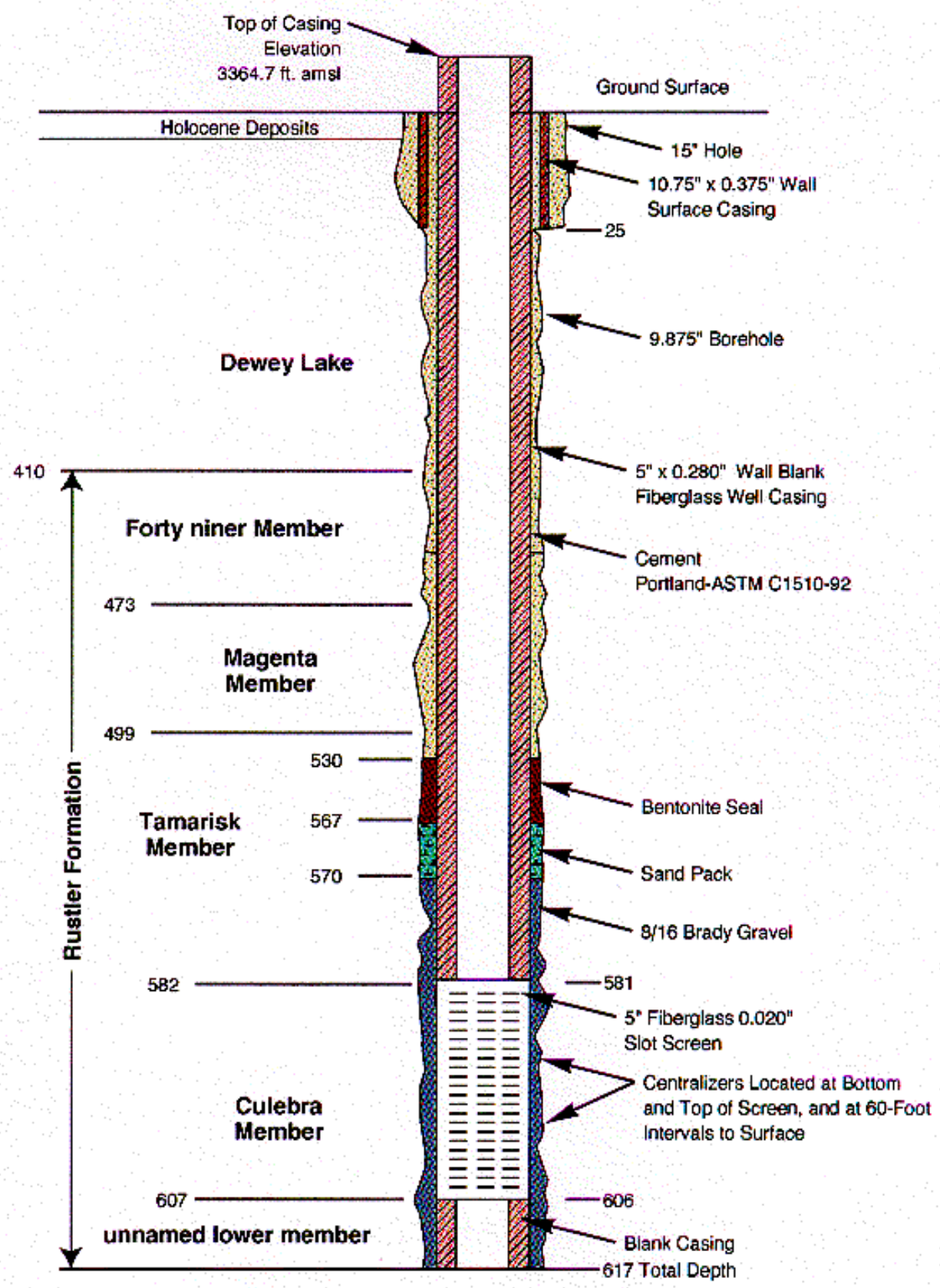

Note: Depths in feet bgs approximate Not to Scale 
Waste Isolation Pilot Plant

Groundwater Protection Management Program Plan

DOE/WIPP 96-2162, Rev. 3

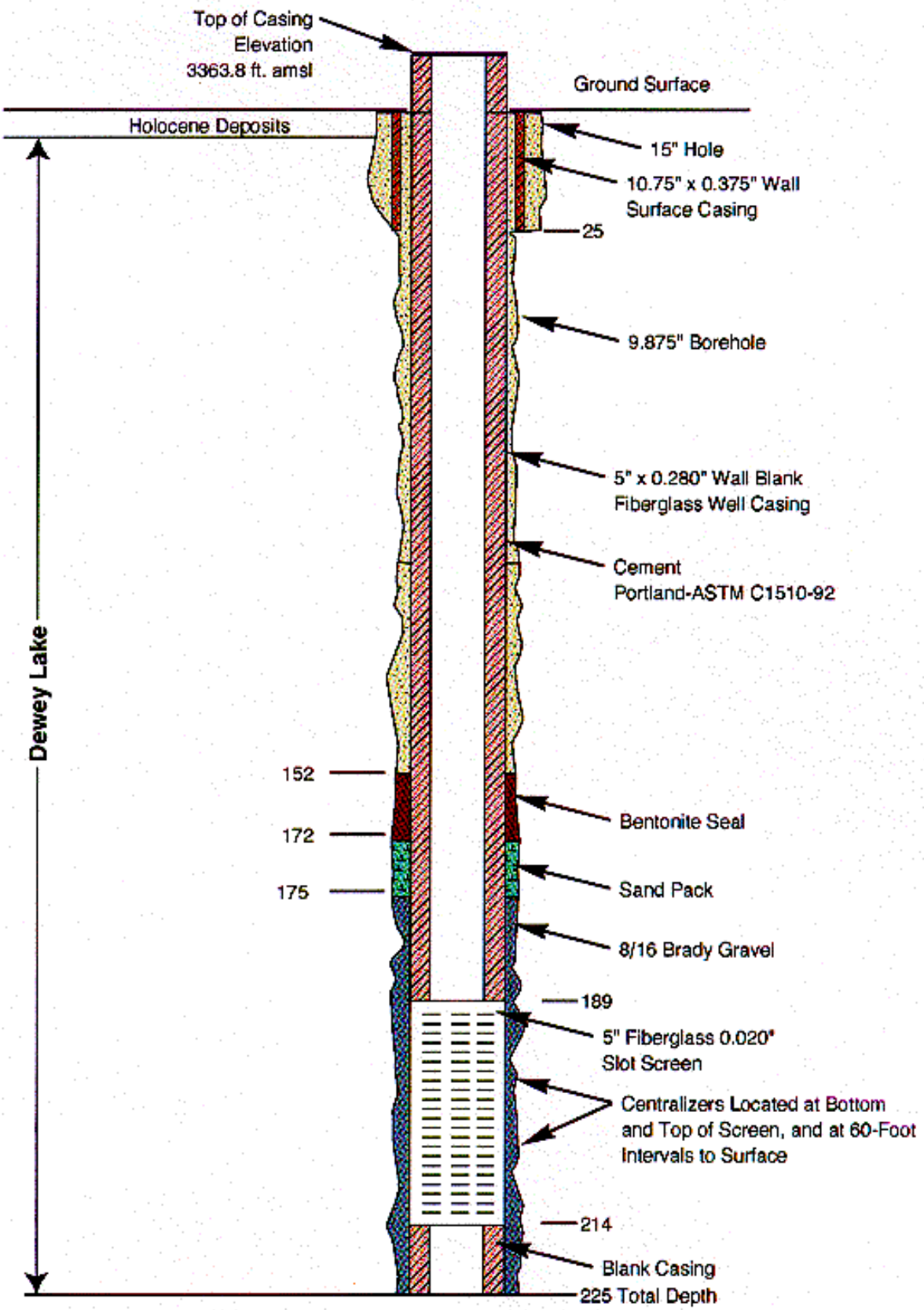

Note: Depths in feet bgs approximate Not to Scale

xmon 114

Figure 3-8 - As-Built Configuration of Well WQSP-6a 


\section{Waste Isolation Pilot Plant \\ Groundwater Protection Management Program Plan \\ DOE/WIPP 96-2162, Rev. 3}

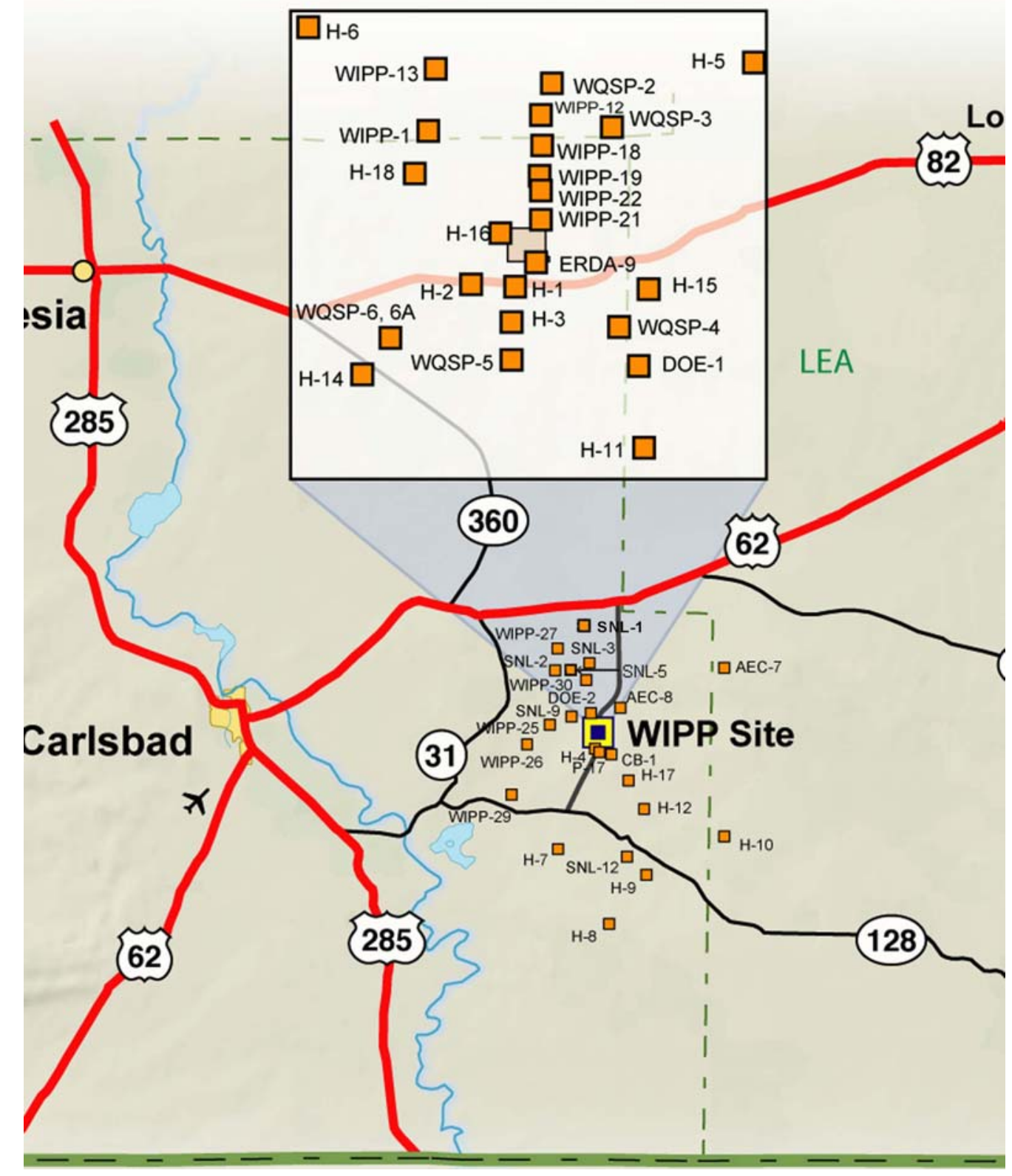

Figure 3-9 - Water-Level Measurement Program Wells 


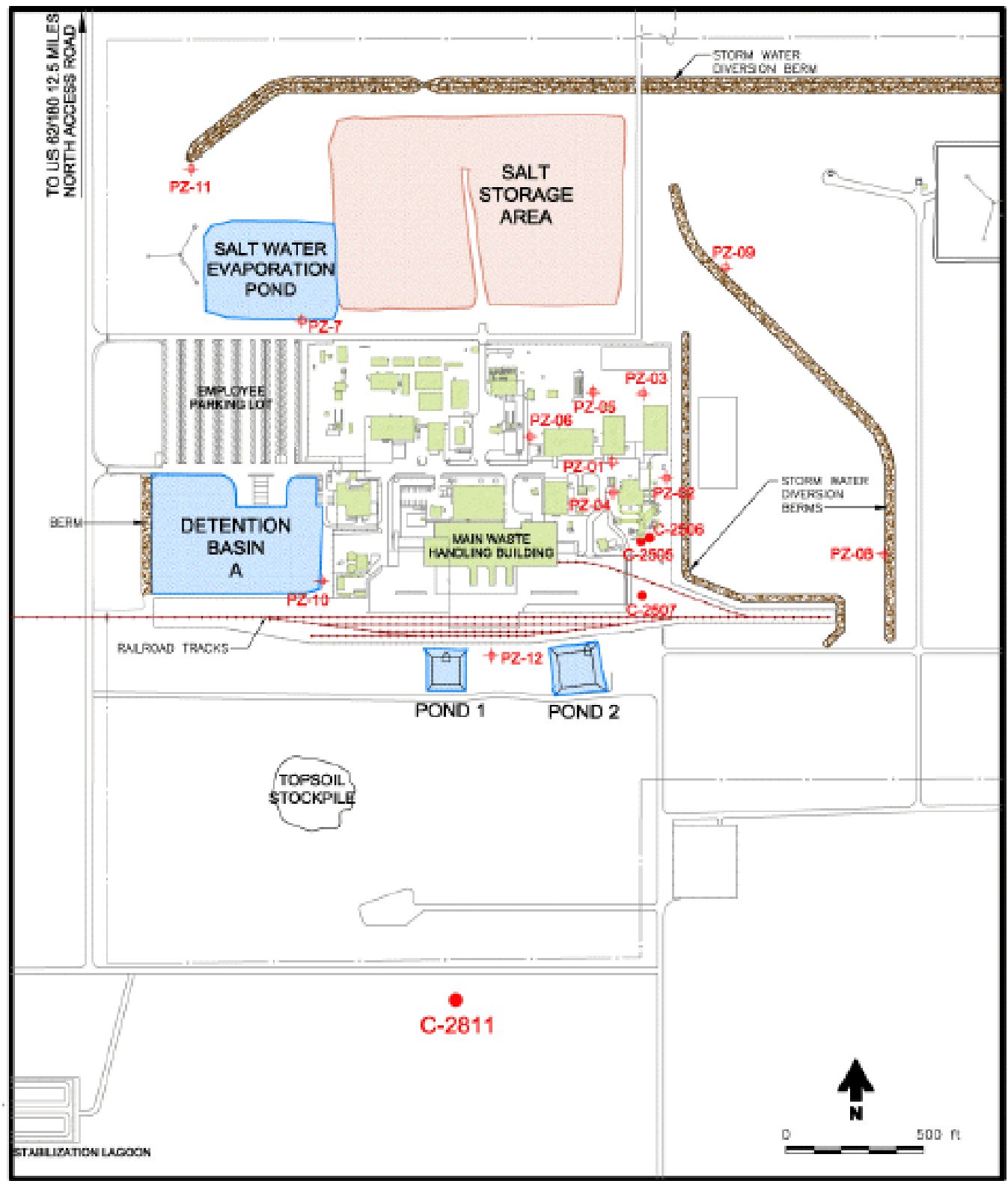

Figure 3-10 - Locations of SSW Wells (Piezometers PZ-1 through 12; Wells C2811, C2505, C2506 and C2507) 


\section{Waste Isolation Pilot Plant \\ Groundwater Protection Management Program Plan \\ DOE/WIPP 96-2162, Rev. 3}

\subsection{STRATEGIES FOR CONTROLLING SOURCES OF CONTAMINANTS}

The WIPP Pollution Prevention (P2) Program and hazardous waste management program, which include waste minimization practices, are the responsibility of WRES Site Environmental Compliance, which works with other organizations to administer the program (Waste Isolation Pilot Plant Pollution Prevention Program Plan, WP 02-EC.11). The Business Management Department coordinates and implements the Affirmative Procurement Program. The Operations Department implements new, pollution-efficient technologies and administers the energy conservation program. The communications organization provides information to WIPP stakeholders about WIPP's commitment to continuous environmental improvement. The communications organization also produces periodic notices, which keeps employees informed of headlines in the local newspaper, safety, and other WIPP-related information. All departments support the recycling program. Finally, the WTS Environmental Management Policy (MP 1.14) requires employees to receive environmental training. This involvement of many departments is indicative of a P2 program that has the commitment of senior management and all site personnel. These departmental responsibilities are part of the WTS program designed to meet International Organization for Standardization (ISO) 14001 program specifications, described in the Environmental Management System Implementation Document (WP 02-EC.0). The WIPP P2 Program follows the P2 hierarchy established in the Pollution Prevention Act of 1990 (42 U.S.C. 13101 et seq.) (P2 Act). The P2 Act establishes source reduction as the first priority for dealing with any waste or pollutant, followed by reuse and recycling, then treatment and, finally, disposal.

At WIPP, WTS implements the P2 Program through WP 02-EC.11. The P2 coordinator implements $\mathrm{P} 2$ projects, promotes employee $\mathrm{P} 2$ awareness, and participates in community outreach programs. The P2 coordinator establishes and promotes the development of waste reduction goals as identified in DOE Orders, Executive Orders, and transfers innovative P2 technology within the DOE complex.

\subsection{REFERENCES}

29 CFR, Labor

40 CFR §§1500-1508, "Regulations for Implementing the Procedural Provisions of the National Environmental Policy Act."

42 U.S.C. $\S \S 2011-2259$, Atomic Energy Act of 1954.

42 U.S.C. §§6901 et seq., Resource Conservation and Recovery Act of 1976.

42 U.S.C. §§13101-13109, Pollution Prevention Act of 1990.

42 U.S.C. $\S \S 4321$ et seq., National Environmental Policy Act of 1969. 


\section{Waste Isolation Pilot Plant \\ Groundwater Protection Management Program Plan \\ DOE/WIPP 96-2162, Rev. 3}

42 U.S.C. §7001, Solid Waste Disposal Act of 1976.

42 U.S.C. $\S \S 9510$ et seq., Comprehensive Environmental Response Compensation and Liability Act of 1980.

42 U.S.C. §§ 10101 et seq., Nuclear Waste Policy Act of 1982.

93 Stat. 1259, 1265, National Security and Military Applications of Nuclear Energy Authorization Act of 1980.

106 Stat. 4777, Waste Isolation Pilot Plant Land Withdrawal Act, October 1992, as amended October 1996 by Public Law 104-201.

Pub. L. 91-512, Resource Recovery Act of 1970.

U.S. Department of Energy, Environment, Safety, and Health Reporting, DOE Order 231.1A, Washington, D.C., 2004.

U.S. Department of Energy, Environment Protection Program, DOE Order 450.1, Washington, D.C., 2005.

U.S. Department of Energy, Radioactive Waste Management, DOE Order 5820.2A, Washington, D.C., Cancelled 1988.

U.S. Department of Energy, Environmental Regulatory Guide for Radiological Effluent Monitoring and Environmental Surveillance, DOE/EH-0173T,

U.S. Department of Energy, Assistant Secretary for Environment, Safety and Health, Washington, D.C., 1991.

U.S. Department of Energy, Design Validation Final Report, DOE/WIPP 86-010, U.S. Department of Energy, Carlsbad, New Mexico, 1986.

U.S. Department of Energy, Waste Isolation Pilot Plant Land Management Plan, DOE/WIPP 93-004, 1993.

U.S. Department of Energy, Contact-Handled (CH) Documented Safety Analysis Report, DOE/WIPP 95-2065, Carlsbad Field Office, Carlsbad, New Mexico, 1995.

U.S. Department of Energy, Title 40 Part 191 Compliance Certification Application for the Waste Isolation Pilot Plant, DOE/CAO 96-2184, U.S. Department of Energy, Carlsbad Field Office, Carlsbad, New Mexico, 1996.

U.S. Department of Energy, Supplemental Information Requested by the New Mexico Environment Department for Solid Waste Management Units, DOE/WIPP 97-2220a, 1997a. 


\section{Waste Isolation Pilot Plant \\ Groundwater Protection Management Program Plan \\ DOE/WIPP 96-2162, Rev. 3}

U.S. Department of Energy, Waste Isolation Pilot Plant RCRA Background Groundwater Quality Baseline Report, DOE/WIPP 98-2285, U.S. Department of Energy Carlsbad Field Office, Carlsbad, New Mexico, 1998.

U.S. Department of Energy, Waste Isolation Pilot Plant Environmental Monitoring Plan, DOE/WIPP 99-2194.

U.S. Department of Energy, Exhaust Shaft Phase III Hydraulic Assessment Data Report October 1997 - October 1998, DOE/WIPP 99-2302, 1999.

U.S. Department of Energy, Geotechnical Analysis Report for July 2000 - June 2001, DOE/WIPP 02-3177, Volume 1, September 2002.

U.S. Environmental Protection Agency, "Environmental Standards for the Management and Disposal of Spent Nuclear Fuel, High-Level and Transuranic Radioactive Waste," 40 CFR Part 191 and Part 194, U.S. Environmental Protection Agency, Washington, D.C., 1985.

U.S. Environmental Protection Agency, RCRA Ground Water Monitoring Technical Enforcement Guidance Document (TEGD), U.S. Environmental Protection Agency, Washington, D.C., September 1986.

U.S. Environmental Protection Agency, Data Quality Objectives for Remedial Response Activities (Development Process), EPA/540/G-87/003, Office of Emergency and Remedial Response, Washington, D.C., March 1987.

U.S. Environmental Protection Agency, "Interim Status Standards for Owners and Operators of Hazardous waste Treatment, Storage, and Disposal Facilities," 40 CFR Part 265, Code of Federal Regulations 40 Parts 190-299, Office of the Federal Register, Washington, D.C., 1989.

U.S. Environmental Protection Agency, Statistical Analysis of Groundwater Monitoring Data at RCRA Facilities, U.S. Environmental Protection Agency, Washington, D.C., 1989.

U.S. Environmental Protection Agency, Corrective Actions for Solid Waste Management Units at Hazardous Waste Management Facilities, Proposed Rule, Federal Register, Vol. 55, No. 145, July 27, 1990.

U.S. Environmental Protection Agency, Statistical Analysis of Groundwater Monitoring Data at RCRA Facilities, Addendum to Interim Final Guidance, U.S. Environmental Protection Agency, Washington, D.C., 1992.

U.S. Environmental Protection Agency, Data Quality Objectives Process for Superfund, Interim Final Guidance, September, EPA 540-R-93-071, 1993. 


\section{Waste Isolation Pilot Plant \\ Groundwater Protection Management Program Plan \\ DOE/WIPP 96-2162, Rev. 3}

U.S. Environmental Protection Agency, Guidance for the Data Quality Objectives

Process, Quality Assurance Management Staff, Washington, D.C.,

EPA QA/G-4, 1994b.

U.S. Environmental Protection Agency, Test Methods for Evaluating Solid Waste, Physical/Chemical Methods, EPA SW-846, 1996

U.S. Environmental Protection Agency, Guidance for Data Quality Assessment, Practical Methods for Data Analysis, EPA QA/G-9, January 1998a,

U.S. Environmental Protection Agency, EPA Region 6 Human Health Medium Specific Screening Levels, Background Document, September, Tables, November 15, 2000.

American Petroleum Institute RP 54, Recommended Practices for Occupational Safety for Oil and Gas Well Drilling and Servicing Operations, American Petroleum Institute, 1999

ASTM E1167-87, Standard Guide for Radiation Protection Program for Decommissioning Operations, American Society of Testing and Materials, 2002

OSHA Publication 2201, General Industry Digest, Occupational Safety and Health Administration, 1991.

Bachman, G. O., "Geologic Process and Cenozoic History Related to Salt Dissolution in Southeastern New Mexico, U.S. Geologic Survey Open-File Report 74-194," 1974.

Beauheim, R. L., "Analysis of Pumping Tests of the Culebra Dolomite Conducted at the H-3 Hydropad at the Waste Isolation Pilot Plant (WIPP) Site," SAND86-2311, Sandia National Laboratories, Albuquerque, New Mexico, 1986b.

Beauheim, R. L., "Interpretations of Single-Well Hydraulic Tests Conducted at and Near the Waste Isolation Pilot Plant (WIPP) Site, 1983-1987," SAND 87-0039, Sandia National Laboratories, Albuquerque, New Mexico, 1987.

Beauheim, R. L., Ruskauff G. J., "Analysis of Hydraulic Tests of the Culebra and Magenta Dolomites and Dewey Lake Redbeds Conducted at the Waste Isolation Pilot Plant Site," SAND 98-0049, Sandia National Laboratories, Albuquerque, New Mexico, 1998.

Crawley, M. E., Hydrostatic Pressure and Fluid Density Distribution of the Culebra Dolomite Member of the Rustler Formation Near the Waste Isolation Pilot Plant, Southeastern New Mexico, DOE/WIPP 88-030, U.S. Department of Energy, Carlsbad, New Mexico, 1988. 


\section{Waste Isolation Pilot Plant \\ Groundwater Protection Management Program Plan \\ DOE/WIPP 96-2162, Rev. 3}

Davies, Peter B., "Variable-Density Ground-Water Flow and Paleohydrology in the Waste Isolation Pilot Plant (WIPP) Region, Southeastern New Mexico, U.S. Geological Survey," Open File Report 88-490, U.S. Department of the Interior, Albuquerque, New Mexico, 1989.

Deal, D. E., and J. B. Case, Brine Sampling and Evaluation Program, Phase 1 Report, DOE/WIPP 87-008, U.S. Department of Energy, Carlsbad, New Mexico, 1987.

Deal, D. E. et al., Brine Sampling and Evaluation Program 1990 Report, DOE/WIPP 91-036, Carlsbad, New Mexico, 1991.

Griswold, G., "Geotechnical Consideration for Radiological Hazard Assessment of WIPP," Report of New Mexico Environmental Evaluation Group, EEG-6, 1980.

Haug, et al., "Modeling of Ground-Water Flow in the Culebra Dolomite at the Waste Isolation Pilot Plant (WIPP) Site in Southeastern New Mexico," Interim Report, Sandia Contractor Report SAND86-7167, Sandia National Laboratories, Albuquerque, New Mexico, 1987.

Holt, R. and D. W. Powers, "Geotechnical Activities in the Waste Handling Shaft," WTSD-TME-038, U.S. Department of Energy, Carlsbad, New Mexico, 1984.

Holt, R., and D. W. Powers, Geotechnical Activities in the Exhaust Shaft, DOE/WIPP-86-008, U.S. Department of Energy, Carlsbad, New Mexico, 1986.

Hunter, R. L., "A Regional Water Balance for the Waste Isolation Pilot Plant (WIPP) Site and Surrounding Area," SAND84-2233, Sandia National Laboratories, Albuquerque, New Mexico, 1985.

Lambert, S. J. and J. A. Carter, 1984, "Uranium Isotope Disequilibrium in Brine Reservoirs of the Castile Formation, Northern Delaware Basin Southeastern New Mexico," SAND83-0144. Sandia National Laboratories, Albuquerque, New Mexico.

Lambert, S. J. and K. L. Robinson, 1983, "Field Geochemical Studies of Groundwater in Nash Draw, Southeastern New Mexico," SAND83-1122, Sandia National Laboratories, Albuquerque, New Mexico.

Lambert, S. J. and Mercer, J. W., 1977, "Hydrology Investigations of the Los Medaños Area, Southeastern New Mexico," SAND77-1401, Sandia National Laboratories, Albuquerque, New Mexico. 


\section{Waste Isolation Pilot Plant \\ Groundwater Protection Management Program Plan \\ DOE/WIPP 96-2162, Rev. 3}

Lappin, A. R., "Summary of Site-Characterization Studies Conducted from 1983 Through 1987 at the Waste Isolation Pilot Plant (WIPP) Site Southeastern New Mexico," SAND88-0157, Sandia National Laboratories, Albuquerque, New Mexico, 1988.

Lusczynski, N. J., "Head and Flow of Groundwater of Variable Density," Journal of Geophysical Research, Vol. 66, No. 12, 1961.

Mercer, J. W., "Compilation of Hydrologic Data from Drilling the Salado and Castile Formations Near the WIPP Site. Southeastern New Mexico," SAND86-0954, Sandia National Laboratories, Albuquerque, New Mexico, 1987.

Mercer, J. W., "Geohydrology of the Proposed Waste Isolation Pilot Plant Site, Los Medaños Area, Southeastern New Mexico," Water Resources investigations, Report 83-4016, U.S. Geological Survey, 1983.

Mercer, J. W. and B. R. Orr, "Review and Analysis of Geologic Conditions Near the Site of a Potential Nuclear Waste Repository Eddy and Lea Counties, New Mexico," U.S. Geological Survey Open-File Rept., 77-123, 1977.

New Mexico Environment Department, Environmental Protection Regulations, 20.4.1.500 NMAC, incorporating 40 CFR $\S \S 264.600$ through 264.603, and 264.00 through 264.101, New Mexico Administrative Code, Santa Fe, New Mexico.

Nowak, J. E., Assessment of Brine Inflow to WIPP Disposal Rooms, Memo from Experimental Programs Division, Sandia National Laboratories, Albuquerque, New Mexico, 1988.

Popielak, R. S., R. L. Beauheim, S. R. Black, W. E. Coons, C. T. Ellingson, and R. L. Olsen, "Brine Reservoirs in the Castile Formation, Waste Isolation Pilot Plant (WIPP) Project, Southeastern New Mexico," TME 3153, U.S. Department of Energy, Albuquerque, New Mexico, 1983.

Powers, D. W., S. J. Lambert, S. E. Shaffer, L. R. Hill, and W. D. Weart, et al., "Geological Characterization Report, Waste Isolation Pilot Plant (WIPP) Site, Southeastern New Mexico," Vol. 1 and 2, SAND78-1596, Sandia National Laboratories, Albuquerque, New Mexico, 1978.

Stormont, J. C. and C. L. Howard, "Development, Implementation and Early Results: Test Series C, of the Small-Scale Seal Performance Test," Sandia National Laboratories, SAND87-2203, 1987.

Stormont, J. C., "Preliminary Seal Design Evaluation for the Waste Isolation Pilot Plant," SAND87-3083, Sandia National Laboratories, Albuquerque, New Mexico, 1988. 


\section{Waste Isolation Pilot Plant \\ Groundwater Protection Management Program Plan \\ DOE/WIPP 96-2162, Rev. 3}

Ward, J. J. and G. Walter, "Aquifer Tests to Determine the Principal Components of Transmissivity in the Culebra Dolomite at Hydropads $\mathrm{H}-4, \mathrm{H}-5$, and $\mathrm{H}-6$ : Waste Isolation Pilot Plant (WIPP), Southeastern New Mexico," SAND83-7009, Sandia National Laboratories, Albuquerque, New Mexico, 1983.

Washington Regulatory and Environmental Services, Groundwater Monitoring Program Plan, WP 02-1, Carlsbad, New Mexico.

Washington Regulatory and Environmental Services, Environmental Management System Description Document, WP 02-EC.0, Carlsbad, New Mexico.

Washington Regulatory and Environmental Services, Waste Isolation Pilot Plant Pollution Prevention Plan, WP 02-EC.11, Carlsbad, New Mexico.

Washington Regulatory and Environmental Services, Metrology Program, WP 10-AD.01, Carlsbad, New Mexico.

Washington TRU Solutions LLC, WTS Environmental Management Policy, MP 1.14, Carlsbad, New Mexico.

Washington TRU Solutions LLC, Washington TRU Solutions LLC Quality Assurance Program Description, WP 13-1, Carlsbad, New Mexico.

Washington Regulatory Environmental Services, WIPP Records Management Plan, WP 15-PR.01, Carlsbad, New Mexico. 